\title{
Electric Vehicles Charging Stations' Architectures, Criteria, Power Converters, and Control Strategies in Microgrids
}

\author{
Dominic Savio Abraham ${ }^{1}\left(\mathbb{D}\right.$, Rajesh Verma ${ }^{2}$, Lakshmikhandan Kanagaraj ${ }^{3}$, Sundar Rajan Giri Thulasi Raman ${ }^{4}$, \\ Narayanamoorthi Rajamanickam ${ }^{1} \mathbb{D}$, Bharatiraja Chokkalingam ${ }^{1, *} \mathbb{D}$, Kamalesh Marimuthu Sekar ${ }^{5}$ \\ and Lucian Mihet-Popa ${ }^{6}$ (D)
}

1 Department of Electrical and Electronics Engineering, SRM Institute of Science and Technology, Chennai 603203, India; agdominicsavio@gmail.com (D.S.A.); narayanamoorthi.r@gmail.com (N.R.)

2 Department of Electrical Engineering Department, King Khalid University, Abha 62529, Saudi Arabia; rkishor@kku.edu.sa

3 Department of Electrical and Electronics Engineering, Adhiparasakthi College of Engineering, Kalavai 632506, India; kkhandan@gmail.com

4 Department of Electrical and Electronics Engineering, Sathyabama Institute of Science and Technology, Chennai 600119, India; sundarrajan.eee@sathyabama.ac.in

5 Department of Electrical and Electronics Engineering, Kongu Engineering College, Tamilnadu 638060, India; kamaleshmeped@gmail.com

6 Faculty of Engineering, Østfold University College, Kobberslagerstredet 5, 1671 Fredrikstad, Norway; lucian.mihet@hiof.no

* Correspondence: bharatiraja@gmail.com

\section{check for} updates

Citation: Savio Abraham, D.; Verma, R.; Kanagaraj, L.; Giri Thulasi Raman, S.R.; Rajamanickam, N.;

Chokkalingam, B.; Marimuthu Sekar, K.; Mihet-Popa, L. Electric Vehicles Charging Stations' Architectures, Criteria, Power Converters, and Control Strategies in Microgrids. Electronics 2021, 10, 1895. https:/ / doi.org/10.3390/electronics10161895

Academic Editor: Taha Selim Ustun

Received: 26 June 2021

Accepted: 30 July 2021

Published: 6 August 2021

Publisher's Note: MDPI stays neutral with regard to jurisdictional claims in published maps and institutional affiliations.

Copyright: (c) 2021 by the authors. Licensee MDPI, Basel, Switzerland. This article is an open access article distributed under the terms and conditions of the Creative Commons Attribution (CC BY) license (https:// creativecommons.org/licenses/by/ $4.0 /)$.
Abstract: The usage of electric vehicles (EV) has been increasing over the last few years due to a rise in fossil fuel prices and the rate of increasing carbon dioxide $\left(\mathrm{CO}_{2}\right)$ emissions. EV-charging stations are powered by existing utility power grid systems, increasing the stress on the utility grid and the load demand at the distribution side. DC grid-based EV charging is more efficient than AC distribution because of its higher reliability, power conversion efficiency, simple interfacing with renewable energy sources (RESs), and integration of energy storage units (ESU). RES-generated power storage in local ESU is an alternative solution for managing the utility grid demand. In addition, to maintain the EV charging demand at the microgrid levels, energy management and control strategies must carefully power the EV battery charging unit. In addition, charging stations require dedicated converter topologies, control strategies, and need to follow set levels and standards. Based on EV, ESU, and RES accessibility, different types of microgrid architecture and control strategies are used to ensure optimum operation at the EV-charging point. Based on the above said merits, this review paper presents different RES-connected architecture and control strategies used in EV-charging stations. It highlights the importance of different charging station architectures with current power converter topologies proposed in the literature. In addition, a comparison of microgrid-based charging station architecture with its energy management, control strategies, and charging converter controls are also presented. The different levels and types of charging stations used for EV charging, in addition to controls and connectors used, are also discussed. An experiment-based energy management strategy was developed to control power flow among the available sources and charging terminals for the effective utilization of generated renewable power. The main motive of the EMS and its control is to maximize the usage of RES consumption. This review also provides the challenges and opportunities in EV-charging, and parameters in selecting appropriate charging stations.

Keywords: microgrid; electric vehicle; energy management controls; renewable energy sources; energy storage unit

\section{Introduction}

Electric vehicles are becoming popular due to their less emissions and lower fossilfuel dependency [1]. The renewable energy sources used in distribution networks, in 
connection with charging station electrification of smart grids, provide a choice for high power conversion efficiency and emission reduction [2]. The microgrid consists of a group of distributed energy sources and energy storage units utilized locally by different types of loads and operated in a grid-connected or islanding mode [3]. A typical EV charging station, as part of a microgrid infrastructure, is shown in Figure 1. However, large capacity penetration of EV charging points increases the demand in charging infrastructure; this impact raises the demand on the utility grid [4]. To mitigate the problems related to power demand, powers generated locally from the RES are integrated with suitable power converter topologies [5]. Charging station facilities are provided by EV manufacturers as a part of their charging infrastructure; for example, Tesla created solar city and Nissan Leaf created sun power [6]. However, charging stations developed using renewable energy integration further reduce the cost of charging and emission, and increase the coordination of the utility grid $[7,8]$.

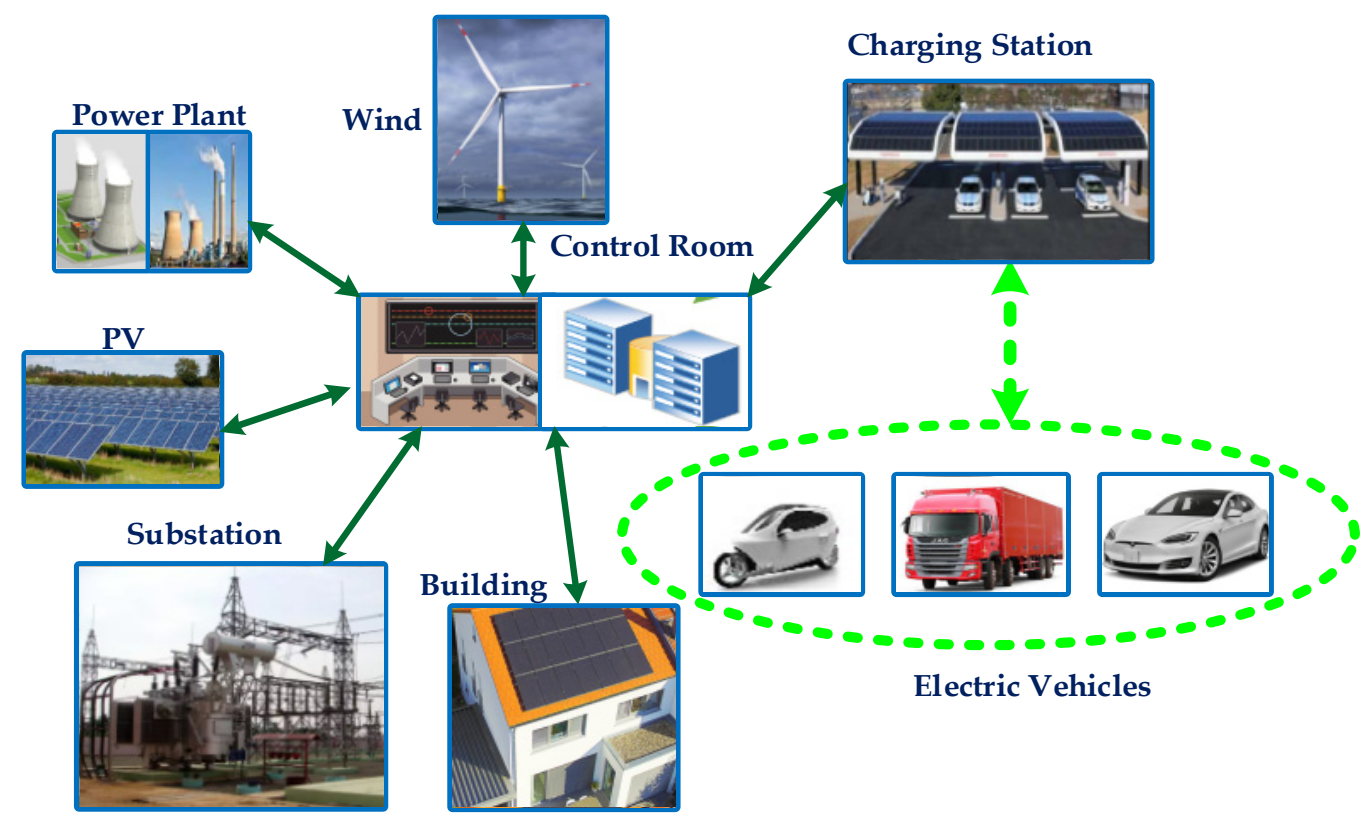

Figure 1. An EV-charging station as part of the microgrid infrastructure.

DC microgrid systems are popular because of their simple voltage regulation and real-time control, also used in DC-powered homes and industrial applications [9-11]. A schematic diagram of EV charging stations with a grid-connected ESU is shown in Figure 2. DC microgrids are designed and operated using a novel topology with a combination of hybrid sources [12,13]. The first low voltage microgrid was proposed in 2002, and is currently experiencing many enhancement changes due to distributed generation [14]. This low voltage microgrid system consists of different scattered energy sources with different types of AC or DC loads. The same development was seen on an AC microgrid in 2004, developed with $10 \mathrm{~kW}$, better reliability, high efficiency, and simple control [15]. Similarly, several DC microgrids have been developed and used for different applications, such as communication systems, and ESU with distributed renewable sources [16].

PV-integrated microgrids are directly connected to EV charging stations using renewable energy without ESU through an EV-PV converter [17-19]. Generally, the PV power generation is variable in nature and its regulation is made through a grid connection. It also has various advantages, such as high quality uninterrupted power supply to the load, automatically isolated from the utility grid during fault conditions, and provides power to the utility grid when deficient $[20,21]$. Different classifications of microgrids used for EV charging are shown in Figure 3. 


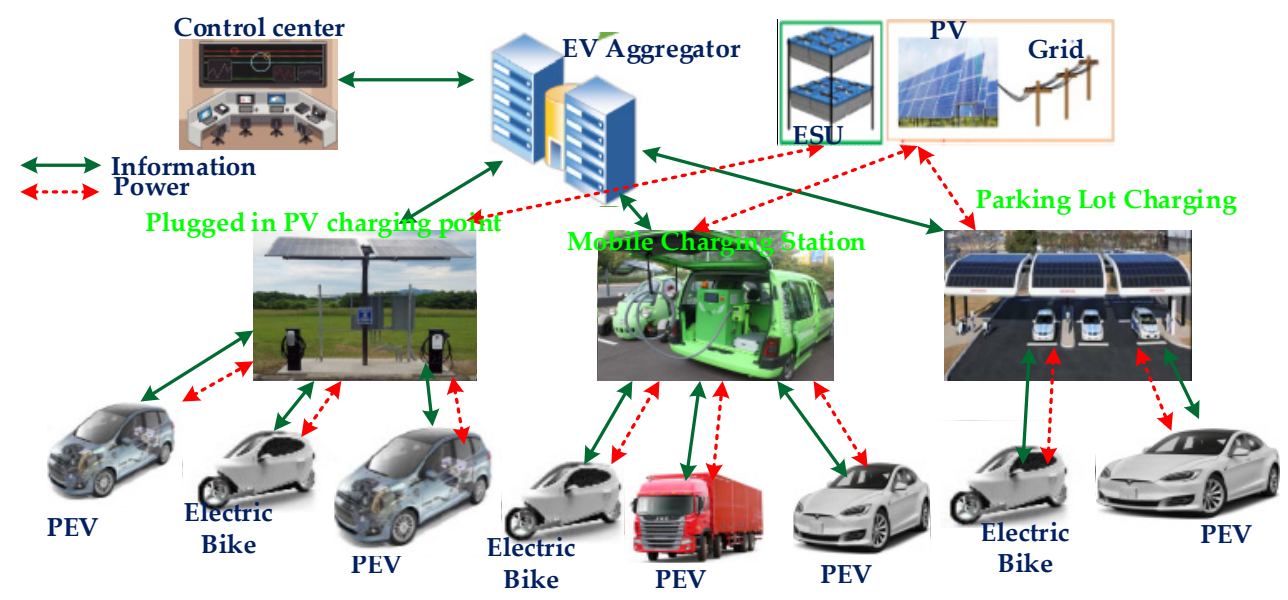

Figure 2. A general schematic of a charging station.

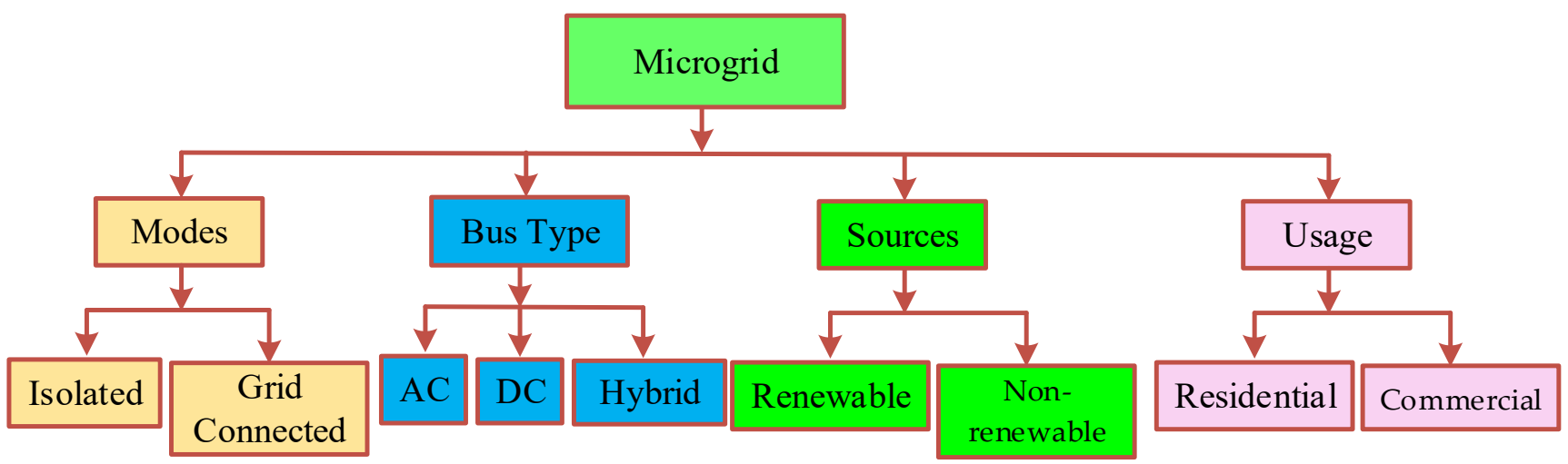

Figure 3. Types of microgrids.

Charging at workplaces through an installed PV in the building's rooftop and parking lot reduces land and initial cost investment [22]. According to a national household survey, $90 \%$ of vehicles are parked for 5 to 6 hours in a parking lot, so workplace charging supports the vehicle in grid (V2G) charging [23]. The charging stations in different places are shown in Figure 4. Regardless of the power source, automobile makers are required to achieve extremely high reliability standards. Furthermore, the enormous energy capacity and potentially volatile nature of some battery technologies pose a serious safety hazard. Reliability, availability, and maintainability are main concerns in charging stations, restricting large-scale commercial utilization of these vehicles. The EV is reliant on grid power and the charging system's dependability [24]. Thus, a grid-connected charging station reliability model was created. It sought to investigate the reliability, availability, and maintainability issues faced by EV charging stations; study how fault events are logically related to one another, how a PEV's reliability is influenced by these fault events, and how proper management strategies can improve a vehicle's availability [25]; and to look into the impact of a charging station on PEV availability. A modified probabilistic index was also proposed to evaluate the power supply's reliability. An IC was designed to be controlled by an external BMS control unit via a serial peripheral interface (SPI), which also allowed for the retrieval of acquired data [26]. EV batteries are charged through conductive coupling, wireless charging, or replaced using battery swapping technique. Wireless charging in the U.K. to test roads that charge electric cars as they drive is shown in Figure 5 [27,28]. 


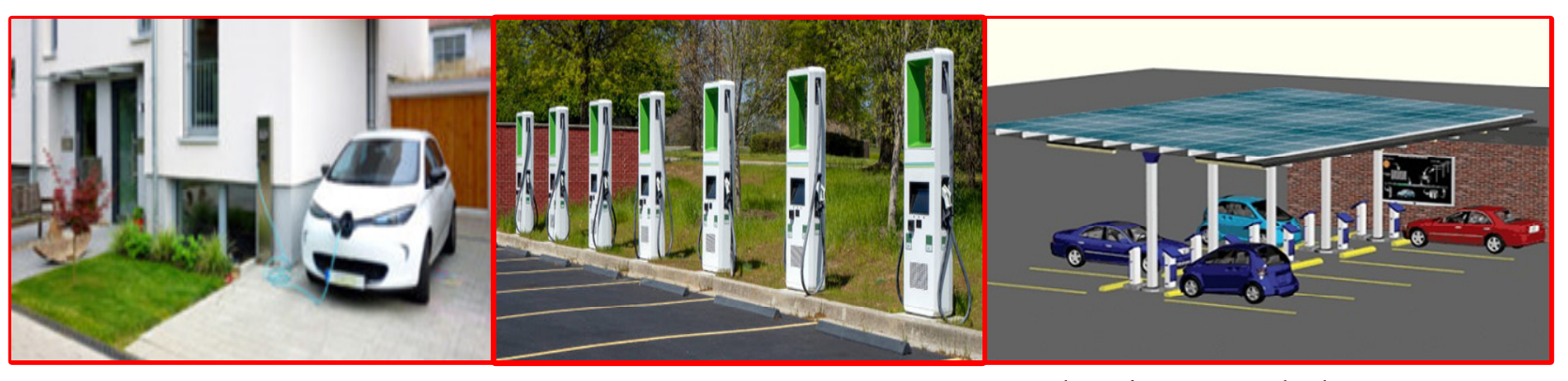

Charging at home

Charging on public networks

Charging at workplace

Figure 4. Charging station in different locations.

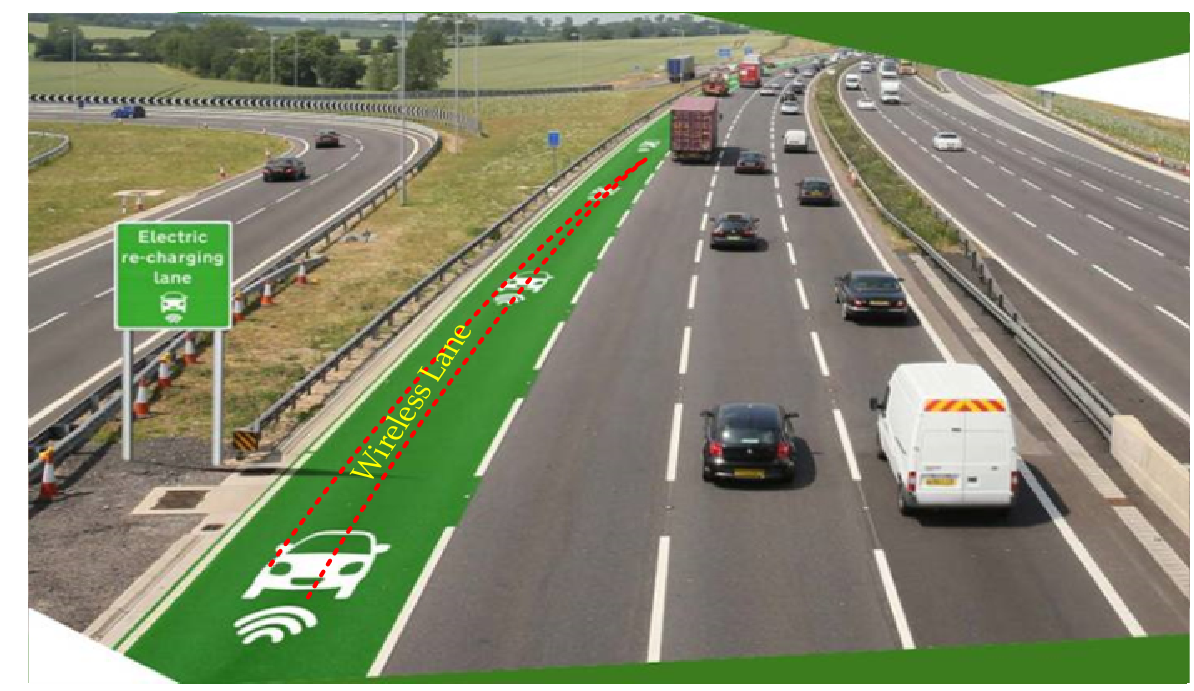

Figure 5. U.K. testing roads that charge electric cars as they drive.

Wireless charging of an EV is done by either inductive or capacitive coupling. In the conductive coupling type, an electrical outlet plug is used to charge the EVs [29]. Here, two separate coils are used for power transfer-one coil is placed inside the vehicle and acts as the receiving coil, while the other one is placed on the parking slot to transfer the power. In capacitive charging, four capacitive plates are used for charging [30]. The cost of the charging can be reduced by developing a level-based charging station. The time taken for charging is reduced through battery swapping technology [22,31,32]. The pros and cons of the types of charging are presented in Table 1 . The different battery swapping stations are shown in Figure 6 [33]. EV chargers are classified into two types: off-board charger and on-board charger. The charger located inside the EV is called an on-board charger and the charger located outside the EV is called an off-board charger [34,35]. A block diagram of the types of chargers is given in Figure 7.

The primary use of an on-board charger is for low power application, and an offboard charger is used for high power DC fast charging [35]. In an on-board charger, EVs are charged from AC sources; the main issues are with power limitation and charging time [36]. Off-board chargers offer fast charging and vehicle-to-grid charging. The benefits and issues of the chargers are presented in Table 2. Energy sources are important in charging stations and most energy generation depends on fossil fuel technology. Hence, a charging station with renewable energy source (RES) requires a large and suitable area for installation $[13,37,38]$. Different combinations of sources are used in EV charging stations. Commonly, photovoltaic (PV) and wind energy are used as RES to integrate with microgrids. Therefore, an RES is a suitable replacement for conventional sources [39], as it also reduces degradation of the environment $[40,41]$. 
Table 1. Pros and cons of different charging systems.

\begin{tabular}{|c|c|c|}
\hline Charging System & Pros & Cons \\
\hline Conductive charging & $\begin{array}{l}\text { Suitable for slow and fast charging } \\
\text { High-efficient charging } \\
\text { Multiple taping possible }\end{array}$ & $\begin{array}{l}\text { Need of standard connectors and cable } \\
\text { Requires complex charging infrastructure }\end{array}$ \\
\hline Wireless charging & $\begin{array}{l}\text { No problems in standardization of connectors } \\
\text { Dynamic charging can be implemented } \\
\text { Charging can be done in all climate conditions }\end{array}$ & $\begin{array}{c}\text { Coil type needs to be standardized } \\
\text { Cost of coil increases vehicle price } \\
\text { Complexity increases on the location of the transmitter } \\
\text { Losses are more in wireless charging }\end{array}$ \\
\hline Battery swapping & $\begin{array}{c}\text { Battery replacement done in less than a minute } \\
\text { With the help of swapping, distance travel } \\
\text { is increased. }\end{array}$ & $\begin{array}{l}\text { Standardization required for battery size and type } \\
\text { Charging station should be able to manage a larger number of batteries } \\
\text { User responsible for battery maintenance }\end{array}$ \\
\hline
\end{tabular}

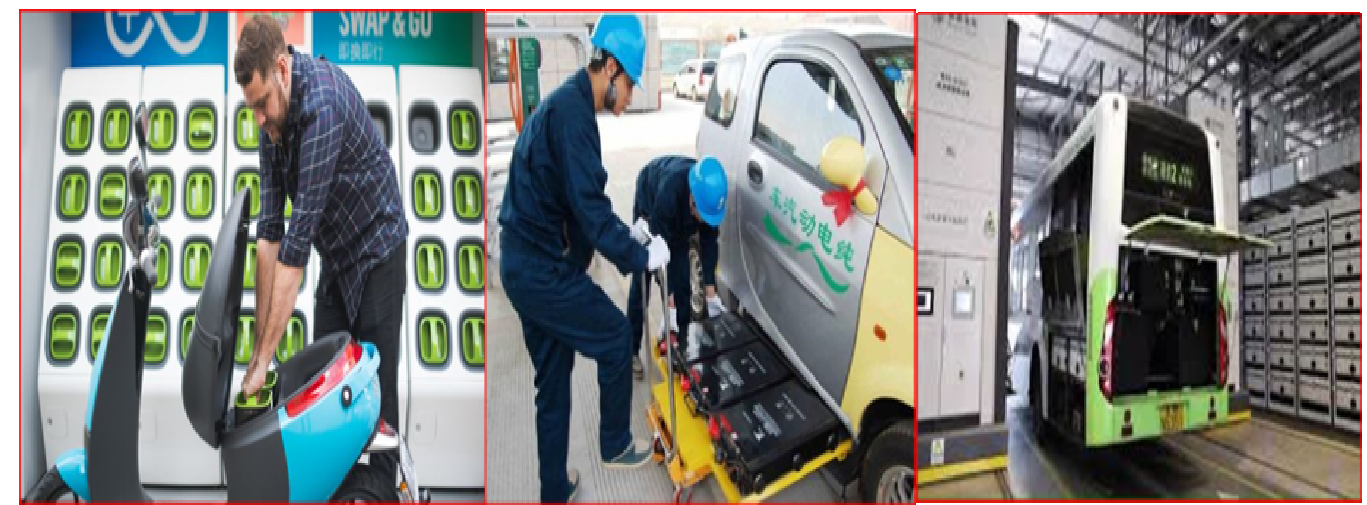

Figure 6. Battery swapping station [33].

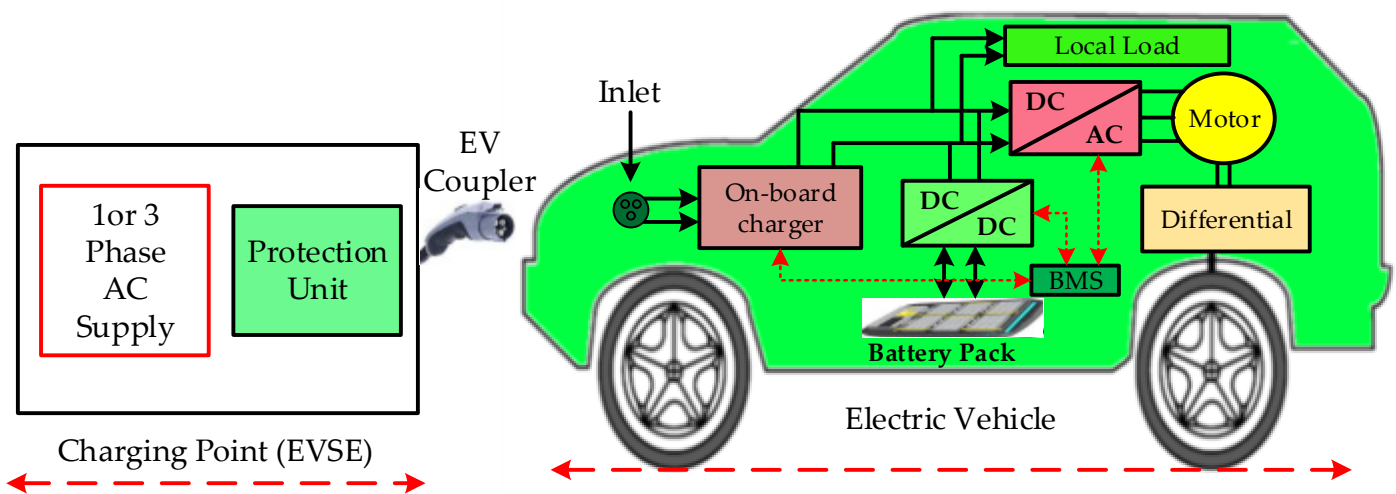

(a)

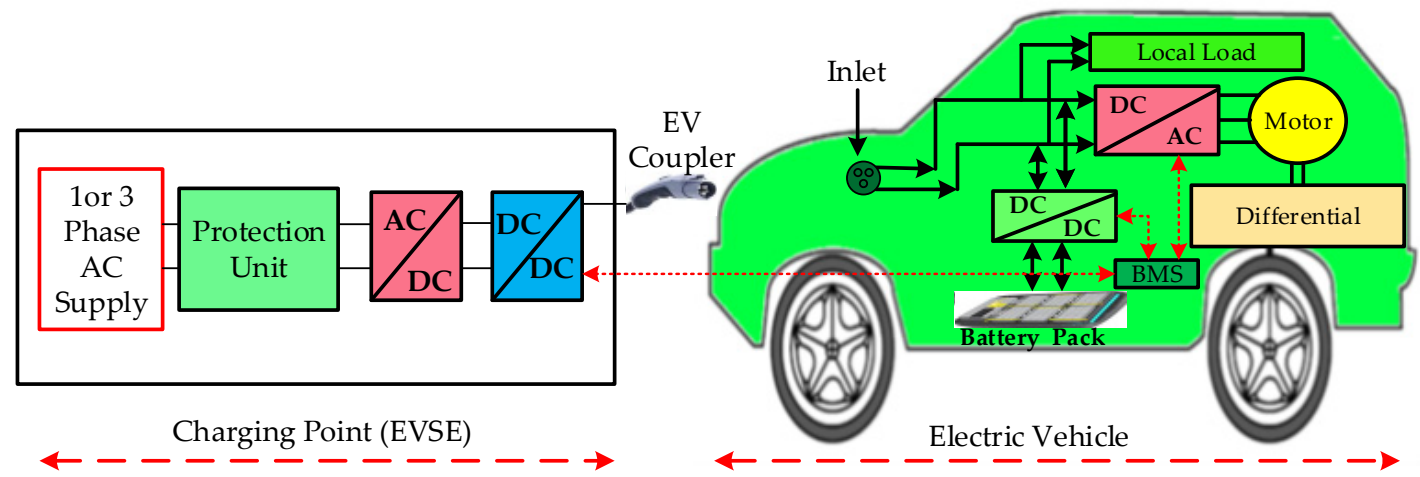

(b)

Figure 7. EV charger: (a) On-board charger arrangement of supply equipment, (b) Off-board charger arrangement of supply equipment. 
Table 2. Challenges and benefits of different types of charging.

\begin{tabular}{ccc}
\hline Charger Type & Benefits and Uses & Challenges \\
On-board & Charge possible at any location with an & electric outlet \\
& Simple BMS can be used & $\begin{array}{c}\text { Slow charging, less power transfer at a time } \\
\text { Difficult to implement vehicle-to anything charging } \\
\text { Weight of charger added to the EV }\end{array}$ \\
\hline Off-board & Used in higher power rating $(\mathrm{kW})$ & Battery heating issue \\
& Foes not add to vehicle weight & $\begin{array}{c}\text { Difficult to allocate places } \\
\text { Cost of charging is high }\end{array}$ \\
\hline
\end{tabular}

In solar power integration, the PV panels are connected in parallel and series combinations. The Wind Energy Conversion System (WECS) consists of blades, gearbox, and generator. Energy production is based on wind speed in a particular area. The installation of WECS with moderate and high wind conditions requires high maintenance costs [42].

The housing/enclosure of a charging station/socket protects the electrical and electronic circuitry against climate conditions and intrusion of objects. For surge protection against lightning strikes and transient over-voltages, a type 2 device according to SS-EN 61643-11 must be installed [43]. A galvanic isolation between the mains and the vehicle is required to avoid unwanted common mode currents. When an emergency stop is needed, the entire load current is interrupted, and all live conductors, including the neutral conductor, are disconnected using an emergency stop button. The electrical and electronic circuitry in a charging station/socket must be protected from external mechanical impacts by the enclosure [44]. The enclosure of a charging station/socket located outside must meet the requirements of IP code 43, as defined by SS-EN 60529. The IP code 43 indicates that housing protects the electrical and electronic circuitry from intrusion by objects larger than $1 \mathrm{~mm}$ in diameter as well as water spray [45].

It is thus clear that charging stations that use different sources need to be studied in detail. Detailed reviews on charging station architecture, standards, converters, and energy management control strategies are few. The main premises of this review paper are:

1. The impacts of selection of charging stations, sizing of the charging systems, and selection of sources. The different sources connected should ensure a suitable charging system, made with different technologies like on-board and off-board chargers. Suitable charging station architecture and selection of sources will reduce costs, dimensions, weights, and power rating, among other factors.

2. Charging stations require standards to connect charging cords, cables, and connectors. The implementation of charging stations with standards can maximize the utilization of charging stations.

3. The cost and performance of a charger depends on the semiconducting devices and its arrangement. All of this impacts one's choice, and the size of the charging system is based on the converter topology used for conversion and gain of the corresponding converter.

4. A charging station with renewable energy reduces the demand in the existing grid system and reduces fossil fuel-based conversion of energy. In addition, the effective use of renewable sources and utilization of sources through energy management increases usage of the EV.

The key contributions and structure of this paper are as follows: This review provides a detailed study of different EV charging architecture when powered by RES. In addition, the converter topology, controls, and various standards and power levels in the charging station are presented. Hence, this review could provide clear motivation for selecting charging station architecture with renewable power and energy storage units. The different charging architectures were compared based on the control strategy of the charging station and feasibility of connecting the ESU. In addition, different energy management approaches are presented to achieve controlled EV charging. 
This paper is structured as follows: Section 2 discusses the review of architecture of multi-point EV charging station and operating principles. Section 3 studies charging station standards and levels. Sections 4 and 5 present EV charging connectors and power electronics converters used in EV charging tied to microgrids, respectively. Sections 6 and 7 present energy management in a DC microgrid-based charging station and control strategy of the charging station, respectively, as well as discusses the challenges and opportunities. Section 9 concludes the paper.

\section{Architecture of Multi-Point EV Charging Stations}

A microgrid-based charging station architecture combines energy sources and ESU localization of distributed loads, offering the capability of operating in a connected grid or in islanding mode. A charging station with renewable energy sources provides an option for charging of the EV without any power conversion losses [46]. There are different types of RES connected to the DC bus, like PV, wind, super capacitor, and fuel cell [37]. Some of the problems in microgrids include steady-state and transient voltage and frequency control [47]. The different types of charging station architectures are shown in Figure 8. In addition, there are problems associated with protection and short circuit, and power quality during islanding and fault conditions of the system [48]. The photovoltaic system is the main source of renewable energy in an RES-powered DC bus system, with a different arrangement to supply power to the local load and EV. This section discusses the different architecture of microgrids used for EV charging. Based on RES and a load connection charging station, a different topology is framed, one that requires a different energy management control strategy $[49,50]$.

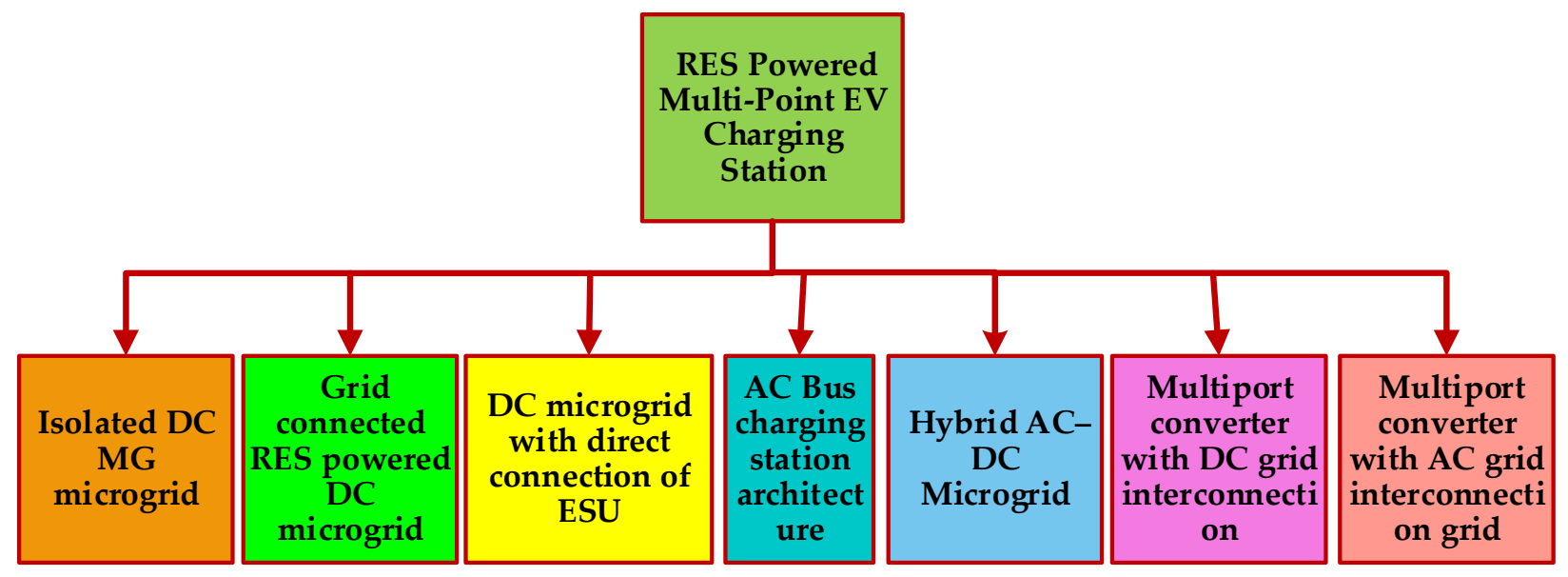

Figure 8. RES Powered Multi-Point EV Charging Station.

\subsection{Isolated DC Microgrid for EV Charging}

An isolated DC microgrid is powered by renewable/non-renewable energy sources such as PV or biofuel generators through dedicated converters. In isolated microgrids, a common DC bus is used for efficient integration storage and renewable energy sources [51]. Diesel generators are frequently used to generate electricity, posing environmental and logistical challenges. Diesel power plants emit a lot of greenhouse gases. Furthermore, diesel must be transported to remote locations, posing concerns, such as leaks on islands. Renewable energy sources (RESs) have thus been implemented in many parts of the world to address such challenges. The generation of renewable energy sources, however, has a lot of changes and uncertainties, which might lead to problems in stability [52]. DC microgrid integration with energy sources is not required for frequency and phase synchronization, like the AC grid system. Therefore, a DC microgrid system can be used when a DC load is connected to the grid. The only problem is that the DC bus voltage needs to be stabilized. This type of microgrid architecture can supply load power based on the power available 
at the generation side [53]. In an isolated DC microgrid system, it is easy to optimize power flows at the DC bus with minimum cost of power control signal and transmission; a structure of this microgrid is shown in Figure 9 [54]. The isolated microgrid-based charging suggests that investing in new PV generation and implementing EV charging techniques for a new fleet will result in a lower microgrid net present cost, particularly if EV penetration is high.

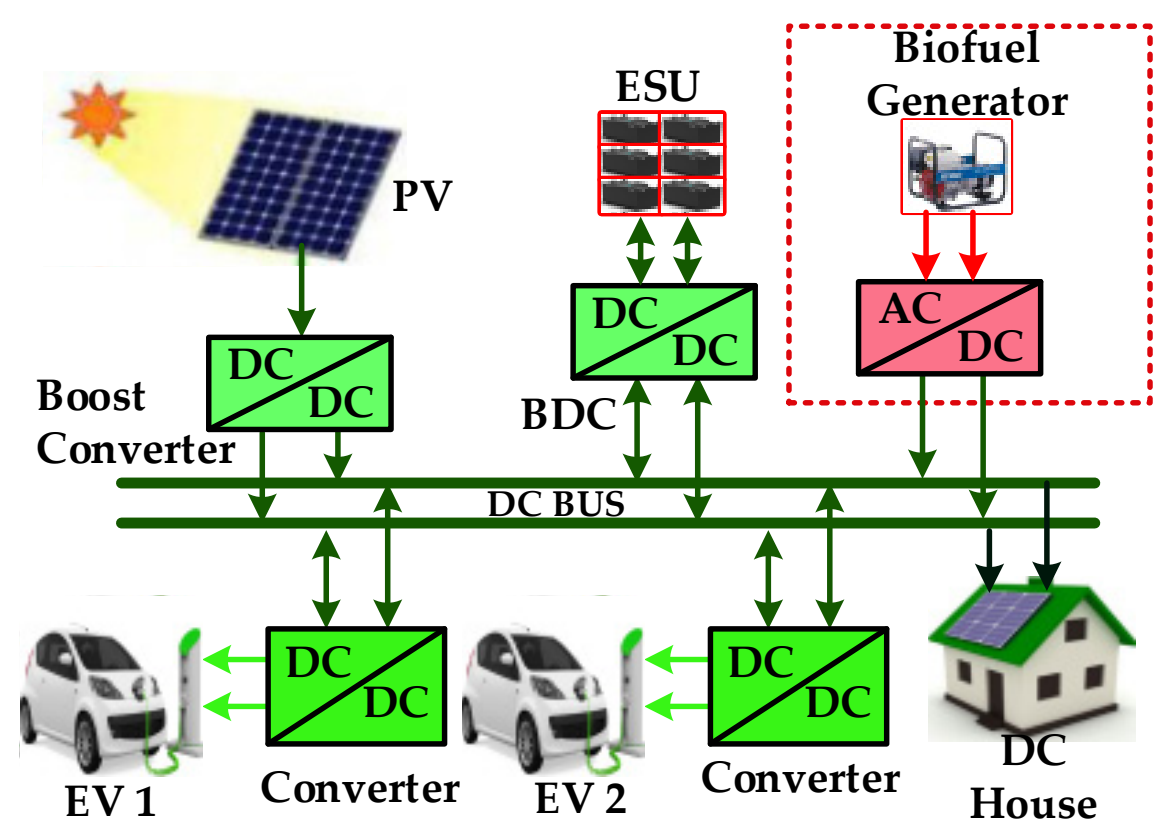

Figure 9. Isolated DC Microgrid.

\section{Isolated DC Microgrid Control Strategy}

The control and management of microgrids are performed based on meteorological conditions and load consumption using short-term forecasting data [55]. Optimizationbased control is mostly followed in this type of microgrid. Optimization is implemented based on the predicted output by satisfying the constraints [56-59].

The DC bus voltage-based control strategy is used for load consumption and generation, and power balancing is performed by controlling energy storage and local biofuel generators [60]. The power control required for a DC isolated microgrid is taken as the reference and denoted as $p^{*}$. Power balancing is done by regulating the DC bus voltage with a proportional-integral controller:

$$
p^{*}=p_{P V}-p_{L}-c_{P}\left(v^{*}-v\right)-C_{i} \int_{0}^{t} d\left(v^{*}-v\right) d t
$$

where $P_{p v}$ is the power supplied by the PV, PL is the power required by the load, $v^{*}$ is the DC bus reference voltage, $\mathrm{CP}$ and $\mathrm{CI}$ are proportional and integral gain of the PI controller, respectively. Then, $p^{*}$ defines a distributed storage and biofuel generator optimized value. The different isolated microgrids and their load control techniques are presented in Table 3. 
Table 3. Isolated microgrid-based EV charging.

\begin{tabular}{|c|c|c|c|}
\hline Reference & Sources & Microgrid Control & Load Control \\
\hline$[61]$ & Solar & $\begin{array}{l}\text { PI controller-based control for charging and } \\
\text { MPPT-based control for PV to DC bus side }\end{array}$ & $\begin{array}{c}\text { Proportional integral PWM } \\
\text { generation-based first quadrant-based DC to } \\
\text { DC converter }\end{array}$ \\
\hline$[62]$ & $\begin{array}{c}\text { PV } \\
\text { Wind, Fuel cell }\end{array}$ & $\begin{array}{l}\text { Simulation dynamic optimization SDO-based } \\
\text { sizing for complete microgrid control }\end{array}$ & $\begin{array}{l}\text { Dynamic wireless power transfer (DWPT) } \\
\text { systems for dynamic charging }\end{array}$ \\
\hline [63] & $\mathrm{PV}$, micro turbine & $\begin{array}{l}\text { Rule-based algorithm with dynamic load } \\
\text { modeling for microgrid control }\end{array}$ & $\begin{array}{l}\text { Mixed integer linear programming for the } \\
\text { energy storage unit }\end{array}$ \\
\hline$[38]$ & PV, wind and diesel generator & $\begin{array}{l}\text { The elements that make up a microgrid can be } \\
\text { optimally dimensioned and managed }\end{array}$ & $\begin{array}{l}\text { Lead-acid battery-aging models and average } \\
\text { ambient temperature and control }\end{array}$ \\
\hline$[64]$ & $\begin{array}{l}\text { PV, wind, biomass, and diesel } \\
\text { generator }\end{array}$ & Invasive weed optimization algorithm & Backtracking search algorithm control \\
\hline
\end{tabular}

The isolated microgrid uses wind diesel isolated microgrids (WDIMs) combined with wind turbine generators (WTGs) and diesel generators (DGs) to supply electricity to remote consumers. The isolated sources can be operated under different modes, such as dieselonly, wind-diesel, and wind-only. In addition, it uses different short-term energy storage technologies like batteries, ultra-capacitors, and flywheels to improve WDIM power quality, stability, and reliability [65-68].

\subsection{Grid-Connected, RES-Powered DC MG for EV Charging}

The grid-connected topology shares a common DC bus between all the sources and load; it also allows the PV and the battery storage to work in parallel [17]. The EVs charged from the PV or ESU mostly depend on RES; the decision depends on power management [34]. The PV is connected to the DC bus using MPPT and ESU is connected using a bidirectional converter. The main drawback of this architecture is DC-to-AC conversion for grid integration. Another characteristic is the ability of the energy storage to feed the grid or load of the households. This architecture can operate in various modes based on the power available at the charging station [69]. This architecture can be used for charging electric vehicle batteries using DC supply, as shown in Figure 10.

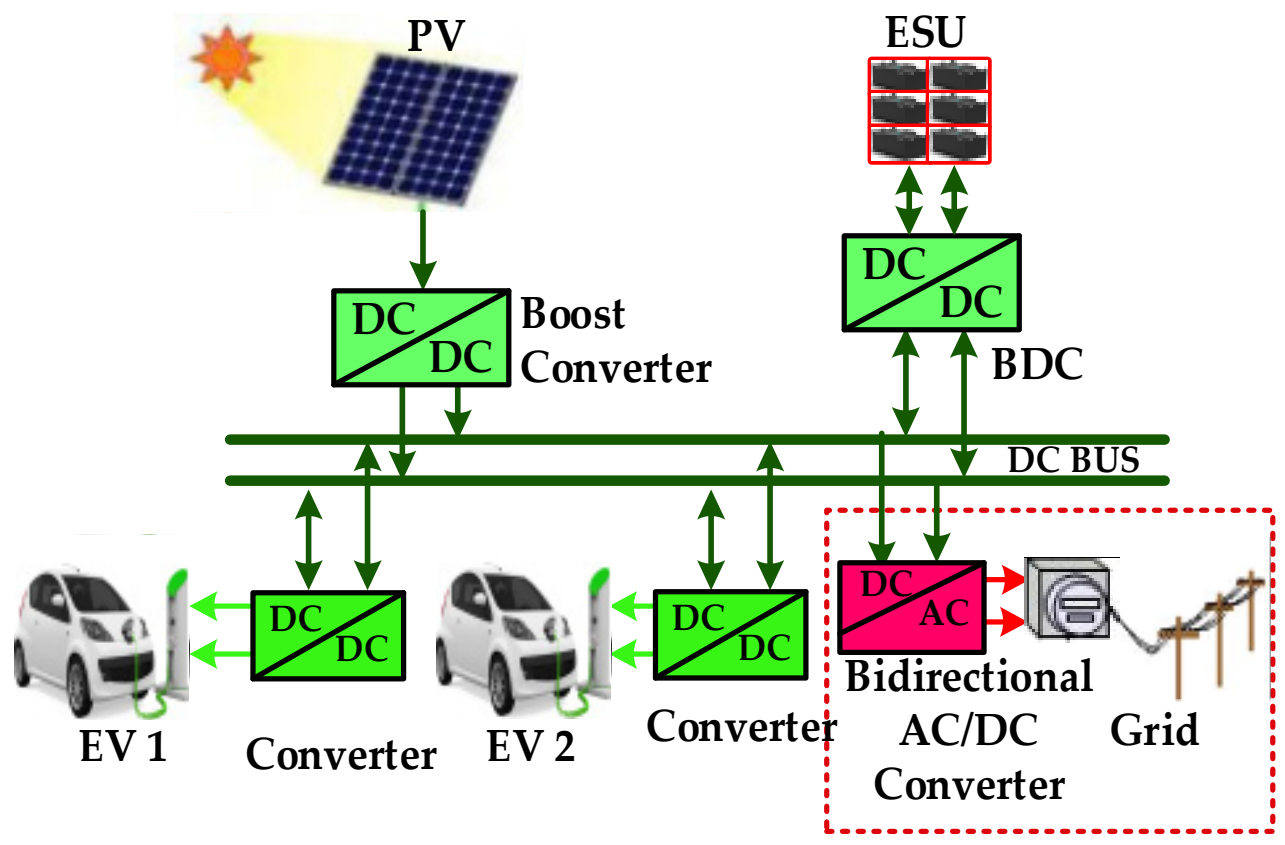

Figure 10. RES-connected DC MG for EV charging with ESU. 
The power prediction model developed depends on an individual customer's power requirements. During huge power demand, the power prediction model acts quickly and efficiently to respond to the charging station $[65,70]$. The power required for charging the $i$ th EV is based on the SOC of the vehicle, plugged time, and charging mode:

$$
P_{E V i}=\frac{\left(S_{E V i, r e q}-S_{E V i}\right) \times C_{E V i}}{P T_{E V i}}
$$

where $S_{E V i, r e q}$ is the required SOC applied by an $i$ th customer using the human machine interface $i, P T_{E V i}$ is the plugged time set to adapt the matched charging mode, $C_{E V i}$ is the battery capacity of the $i$ th EV. During the time of multiple EV connections, power demand is calculated from the following equation:

$$
P_{E V S}=\sum_{i=1}^{N} P_{E V i}
$$

When a particular EV ( $i$ th EV) is connected to the charging point, the energy management system will measure from the human machine interface of the ith and compensate for the lack of power for EV charging. The real-time monitoring of the ESU with respect to $P T_{E V i}$ is:

$$
P_{B S B}=\frac{\left(S_{E S U}-S_{E S U, o p t}\right) \times C_{E S U}}{\sum_{i=1}^{N} P_{E V i}}
$$

where $S_{E S U, \text { opt }}$ is the rate of SOC at which ESU should be off service, $C_{E S U}$ is the ESU capacity, and SESU is the instantaneous SOC. The power prediction model measures each charging point power requirement and provides optimum power to the EV user and the charging station owner. The different control methodologies of the grid-connected, RES-powered DC microgrid control strategy are presented in Table 4.

Table 4. Comparison of control methodology.

\begin{tabular}{cccccc}
\hline Reference & Renewables & Microgrid Control & ESU Capacity & EV Type & EV Charging and Load Control \\
\hline$[71]$ & PV & Droop control & - & PEV & $\begin{array}{c}\text { Load regulation through over-voltage and } \\
\text { over-current regulation control }\end{array}$ \\
\hline$[50]$ & PV & $\begin{array}{c}\text { Dynamic optimal } \\
\text { power flow control }\end{array}$ & $1000 \mathrm{kWh}$ & PEV & $\begin{array}{c}\text { Smart load management control strategy } \\
\text { based on cost estimation from generating } \\
\text { energy and losses }\end{array}$ \\
\hline$[72]$ & PV & $\begin{array}{c}\text { Rule-based control of } \\
\text { DC LINK voltage }\end{array}$ & $130 \mathrm{Ah}$ & PHEV & PI-PWM control of charging \\
\hline$[18]$ & $\mathrm{PV}$ & $\begin{array}{c}\text { Power management } \\
\text { control }\end{array}$ & (SMES) $6 \mathrm{H} / 300 \mathrm{~A}$ & EV & $\begin{array}{c}\text { PI controller-based charging of EV and } \\
\text { superconducting magnetic energy } \\
\text { Storage (SMES) }\end{array}$ \\
\hline$[73]$ & $\mathrm{PV}$ & $\begin{array}{c}\text { Circulating currents } \\
\text { elimination }\end{array}$ & EV & $\begin{array}{c}\text { Accumulated total neutral-point current } \\
\text { control used to reduce voltage ripple in } \\
\text { charging output. }\end{array}$ \\
\hline$[74]$ & PV, Wind & $\begin{array}{c}\text { Model predictive } \\
\text { controller (MPC) }\end{array}$ & $24 \mathrm{kWh}$ & EV & Constant current and voltage loop control \\
\hline
\end{tabular}

In the DC microgrid based system, a proper control strategy should be used to avoid the circulating current providing optimal operation. In addition, droop control architecture can be used to maintain DC bus voltage. Furthermore, advanced controls like hierarchical control architecture, fuzzy control architecture, and multi-agent-based control architecture can be used for maintaining voltage fluctuations. The limited capacity of the energy storage system is necessary to overcome fluctuation of DC Bus voltage and maintain power balance [72,75-78]. 


\subsection{RES-Powered DC Microgrid with Direct Connection of ESU}

The RES of PV connected using a unidirectional converter and ESU using electrochemical battery stacks are directly connected to the DC bus. A PV converter controlled through maximum power point tracker (MPPT) provides regulated supply to the utility grid [79]. The numbers of series battery cells are determined depending on the DC bus voltage. If the ESU is directly connected to the DC bus, it is required to regulate the charging voltage [80]. The direct connection of ESU will cause a circulating current problem that leads to uneven loading of those converters. To control the power flow, communication between the converter and inverter is required using a coordinated control strategy [81]. The RES-powered DC microgrid with a direct connection of ESU is shown in Figure 11.

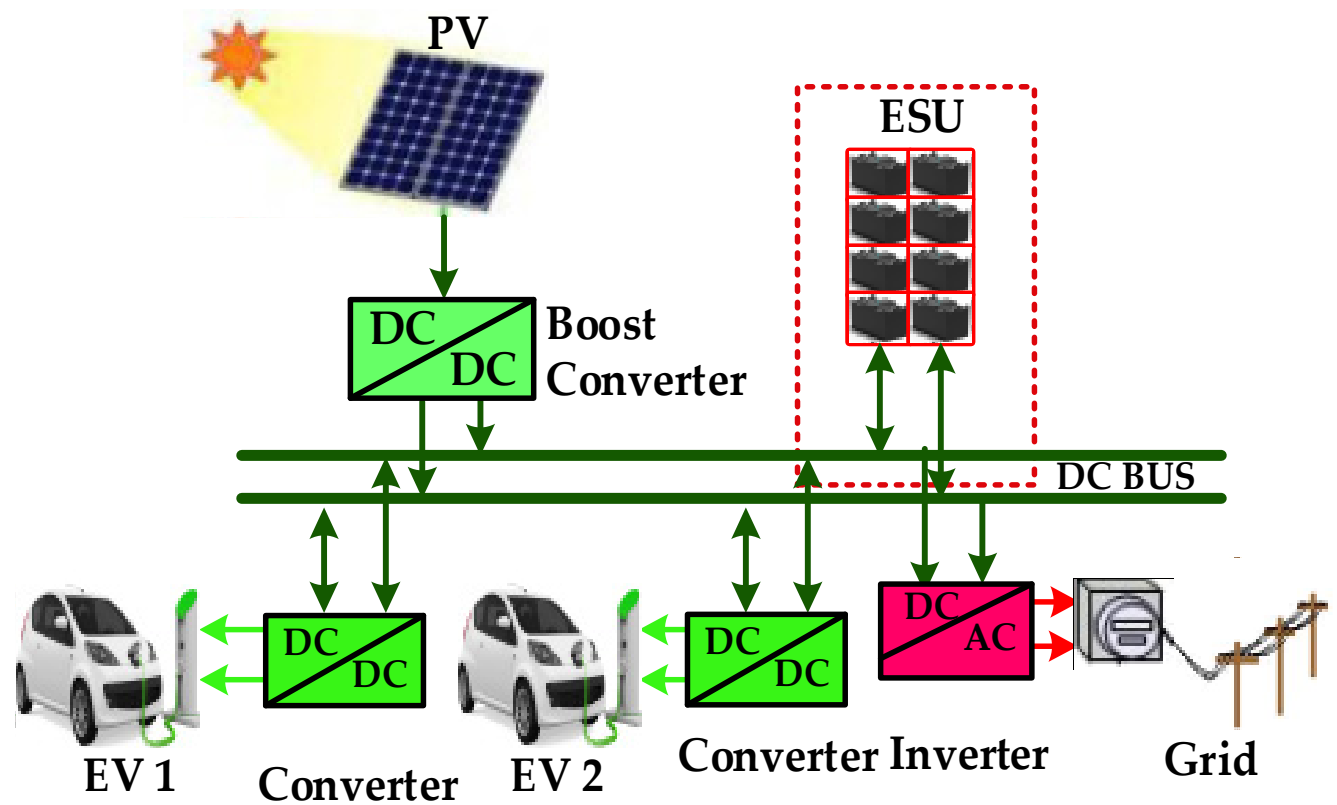

Figure 11. RES-connected EV charging with ESU.

Modes of Operation and Control Algorithm

The type of charging station architecture depends on the control strategy of the DC link voltage control. The PV is connected to the charging station's DC link voltage, which varies based on the irradiation on the PV panel. The reference DC bus voltages are chosen based on the different sun conditions from early morning to late evening. The overall control of RES-powered DC MG with a direct connection of ESU is presented in Table 5.

Table 5. Comparison of control methodology of RES-powered DC MG with a direct connection of ESU.

\begin{tabular}{|c|c|c|c|c|}
\hline Reference & Renewables & Microgrid Control & EV Type/Motor & EV Charging and Load Control \\
\hline [82] & PV & $\begin{array}{l}\text { DC link voltage-based } \\
\text { control }\end{array}$ & PHEV & $\begin{array}{c}\text { Control of load depends on the SOC available at the } \\
\text { vehicle battery, based on the reference level } \\
\text { operated in CV or CC mode }\end{array}$ \\
\hline [83] & PV & Rule-based control & PHEV & $\begin{array}{l}\text { Load current requirement is measured by power } \\
\text { conditioner monitors }\end{array}$ \\
\hline [84] & PV & $\begin{array}{l}\text { Fuzzy logic power-flow } \\
\text { controller }\end{array}$ & PHEV & $\begin{array}{l}\text { Based on the real-time estimation of the load } \\
\text { availability with total generating cost-based } \\
\text { prediction control }\end{array}$ \\
\hline [85] & PV and wind & Supervisor control & $\begin{array}{l}\text { Different } \mathrm{AC} \text { and } \mathrm{DC} \\
\text { loads }\end{array}$ & $\begin{array}{l}\text { Custom-made supervisor control capable to } \\
\text { efficiently administrate diverse energy }\end{array}$ \\
\hline [66] & Wind & $\begin{array}{l}\text { LabView control } \\
\text { algorithm }\end{array}$ & Brushed PM DC motor & $\begin{array}{c}\text { Relationship between frequency and DC } \\
\text { voltage-based control }\end{array}$ \\
\hline
\end{tabular}


The microgrid with direct connections of ESU is the most common type of DC MG, frequently deployed in practical industrial applications. Based on the DC bus, the ESU, used as electrochemical battery stacks, is directly connected. However, the architecture creates dynamic stability, such as uncontrollable DC bus voltage, SOC, and current limitation [86]. It is most suitable for singular DC bus systems, however, creating practical problems like unregulated battery charging and inherent imperfections in bus voltage measurement.

\subsection{AC Bus Coupled Charging Station Architecture}

In AC-coupled microgrid architecture, all the loads are connected to the common $\mathrm{AC}$ bus, as shown in Figure 12. In this, the ESU is connected to the AC bus through the AC-to-DC bidirectional converter [87]. This type of architecture gives an option for sizing of all the parts independently. The connection to the grid and local load might provide more flexibility to the system in terms of charge and discharge of the battery and peak time management [88]. The AC bus-coupled architecture is preferred for home-based charging due to its well-defined standards. In addition, AC technology and its products are already available in the market [89]. However, considering renewable energy sources, solar integration DC bus-based systems are more efficient due to fewer amounts of conversion loss. The AC grid-based charging station requires power compensation to measure active power at the point of common coupling [35].

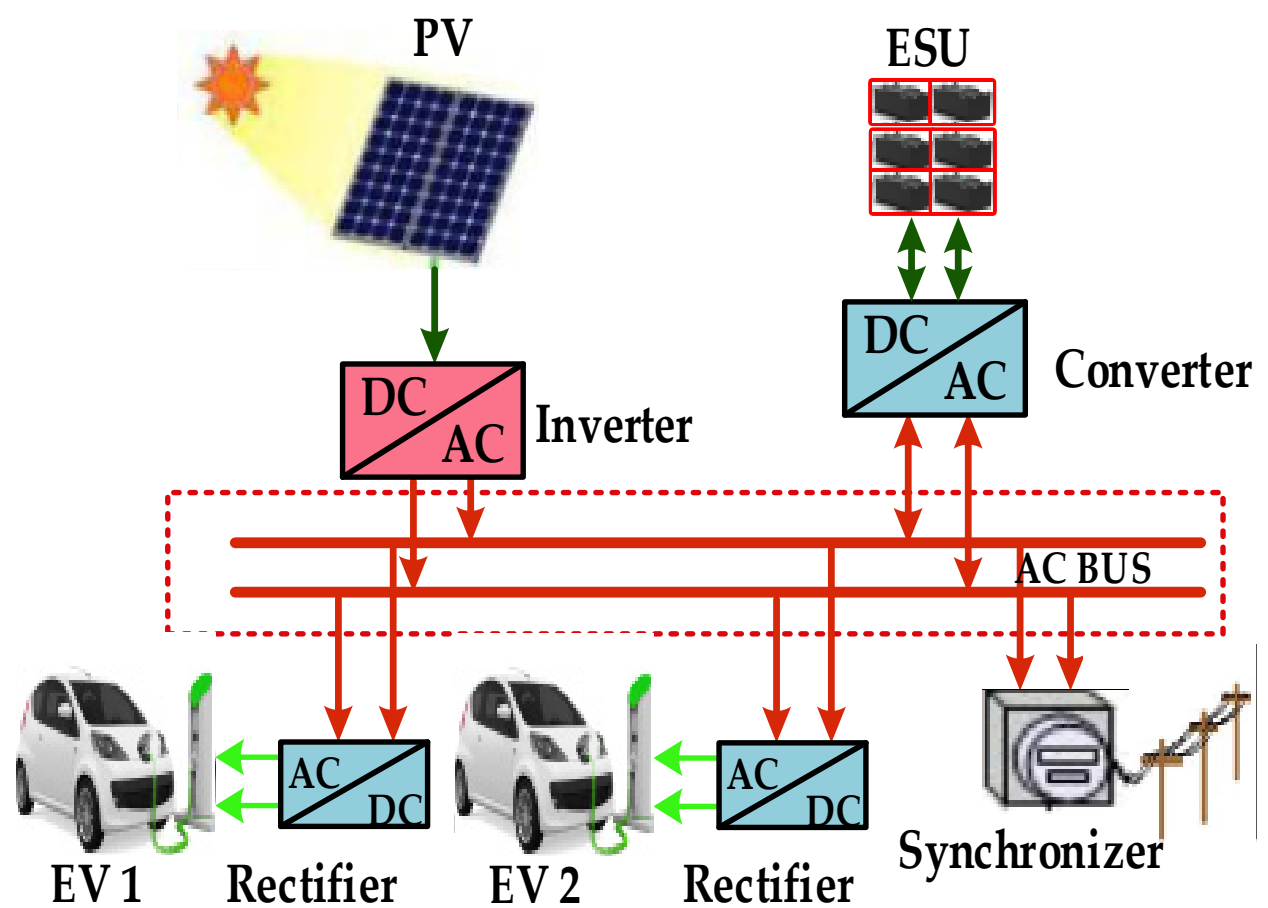

Figure 12. AC bus-coupled charging station architecture.

\section{AC Bus-Connected Charging and Discharging Control}

To exchange power between microgrids to a high-capacity power grid, the equilibrium state of the microgrid is followed. If the power of the ESU is greater than zero, it is considered a discharge state; if not, it is considered as the charging state. Different intelligent algorithms are used-mainly GA, AFS, and PSO [90,91]. PSO computes information through the current optimal location, and GA computes information between all chromosomes. The PSO has higher fitness and less computing time. A comparison of the AC bus-coupled charging station architecture controls are presented in Table 6. 
Table 6. Comparison of AC bus-coupled charging station architecture controls.

\begin{tabular}{|c|c|c|c|c|c|}
\hline Reference & Renewables & Microgrid Control & Load & ESU Capacity & Load Control \\
\hline$[92]$ & PV & $\begin{array}{c}\text { Two types of algorithm are } \\
\text { used-stochastic dynamic } \\
\text { programming (SDP) algorithm } \\
\text { and greedy algorithm (benchmark } \\
\text { algorithm) }\end{array}$ & EV & - & $\begin{array}{l}\text { A linear regression model is used } \\
\text { for load prediction and control }\end{array}$ \\
\hline [93] & - & $\begin{array}{c}\text { The smart metering-based } \\
\text { microgrid control is used with } \\
\text { Modbus on an TCP/IP connection } \\
\text { using the internal LAN }\end{array}$ & EV & $30 \mathrm{kVA}$ & $\begin{array}{l}\text { An SOC prediction-based load } \\
\text { control is followed. }\end{array}$ \\
\hline$[94]$ & PV & $\begin{array}{l}\text { EMS is used to optimize power } \\
\text { generation and use of different } \\
\text { sources and loads to minimize the } \\
\text { total cost, while satisfying the } \\
\text { load and device constraints. }\end{array}$ & $\mathrm{EV}$ & Optimization & $\begin{array}{l}\text { Keeping in mind the high loading } \\
\text { impacts of the EV, typical } \\
\text { EV-charging methods were } \\
\text { incorporated. }\end{array}$ \\
\hline$[64]$ & PV and Wind & Frequency-based control & $\begin{array}{l}\text { Balanced } \\
\text { load }\end{array}$ & 7.3 MWh & $\begin{array}{l}\text { The frequency and SOC-based } \\
\text { control are used to provide } \\
\text { high-quality power to the } \\
\text { connected loads }\end{array}$ \\
\hline [17] & PV\&Wind & Supervisor control & $\begin{array}{l}\text { Different AC } \\
\& \text { DC Load }\end{array}$ & & $\begin{array}{l}\text { Custom-made supervisor control } \\
\text { capable to efficiently administrate } \\
\text { the diverse energy forms }\end{array}$ \\
\hline
\end{tabular}

The advantage of an AC microgrid-based distribution systems is that it can distribute over distance and can be stepped up or down. Stable voltage can be obtained by controlling reactive power and real power independently. In the grid-connected mode, when the main grid experiences an abnormal or faulty condition, the AC microgrid will isolate itself to protect the load within the microgrid $[87,88]$. The main advantage of AC microgrid-based charging stations is that all the existing loads are operated with an AC source; it reduces conversion losses, but DC loads are the dominant load in the charging station. Due to this conversion, efficiency is reduced.

\subsection{Hybrid AC-DC Microgrid}

A hybrid microgrid is the concept of combining both $\mathrm{AC}$ and DC microgrid distribution systems, as shown in Figure 13. Hybrid microgrids use relative merits of both AC and DC microgrids, and offers the advantages of both [95]. All DC power sources, like photovoltaic (PV) systems and fuel cell (FC), are connected to DC microgrids through DC-DC boost converters [96]. Similarly, DC loads such as electric vehicles are connected to DC microgrids through DC-DC buck converters. In addition, the AC grid is connected to the sources of wind turbine generators, small diesel generators, and utility grid systems [97]. AC grid voltages are maintained as $230 \mathrm{~V}$ or $400 \mathrm{~V}$ to connect AC loads such as AC motors. A hybrid microgrid-based charging system commonly uses an AC supply system or is otherwise connected to the RES. There are various advantages while implementing coordinated charging, which includes bus voltage regulation, frequency regulation, and island condition. In power sharing mode the utility grid absorbs energy from the DC microgrid and maintains grid balance $[50,65]$. 


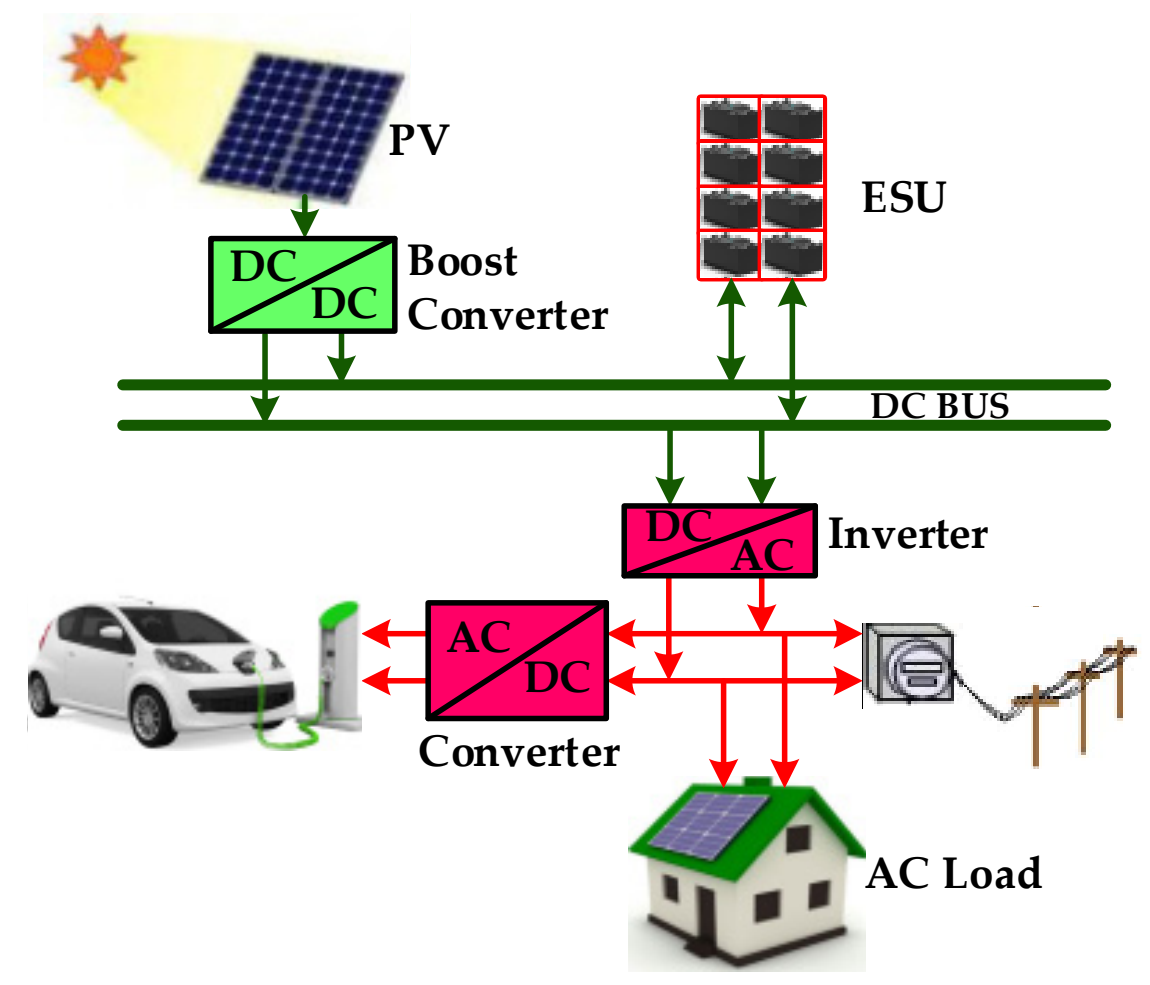

Figure 13. Hybrid AC-DC microgrid architecture.

\subsubsection{AC and DC Charging Station and Its Control}

Control of the entire system requires the bidirectional control system for both $\mathrm{AC}$ and DC bus [98]. A three-layer coordinated control algorithm was developed to control the hybrid AC-DC micro grid to coordinate the sources without overlapping each other [99]. Different layers perform distinct operations; the first maintains DC grid voltage and provides coordinated supply to all DC charging points. The second layer controls the AC bus RMS voltage regulation and maintains the frequency from the three-phase AC grid. The third layer operates between AC and DC microgrids through an interlinking converter. Its control facilitates different power flow operations, such as from vehicle to grid and PV to ESU. The control actions of the charging point are done through a localized controller, but the overall control of the charging station is managed through the main controller $[66,95]$.

\subsubsection{Frequency Droop Control}

The hybrid microgrid's control and power sharing is done through frequency droop control with the measurement of active $(\mathrm{P})$ and reactive power $(\mathrm{Q})$, as shown in Figure 14 [100]. The frequency droop control maintains reference frequency and the corresponding voltage amplitude equations as follows:

$$
\begin{gathered}
f_{i}=f_{i}^{*}-\pi r^{2}, \\
f_{i}=f_{i}^{*}-m_{i} X\left(P_{i}-P_{i}^{*}\right) \\
V_{i}=V_{r i}^{*}-n_{i} X\left(Q_{i}-Q_{i}^{*}\right)
\end{gathered}
$$

where $V_{r i}^{*}$ is the reference rated voltage of the DC bus, $f_{i}^{*}$ is the reference rated microgrid operating frequency. $P_{i}^{*}, Q_{i}^{*}$ are the rated value of real and reactive power and $P_{i}, Q_{i}$ are the measured real and reactive powers, respectively. Here, $\mathrm{m}$ and $\mathrm{n}$ are the droop coefficients derived for the maximum ratings of the load. 


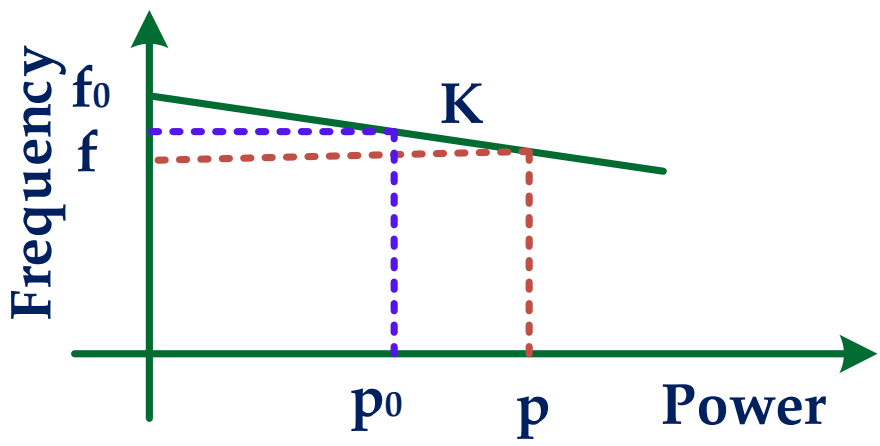

Figure 14. Frequency droop control characteristics.

\subsubsection{Angle Droop Control}

The angle droop control used when all the DGs are interfaced with the microgrid is shown in Figure 15 [100]. By controlling the angle between the voltage and current, real and reactive power is controlled [22]. By comparing voltage magnitude, the converter's real or reactive power is given to the DC microgrid, and control signals are derived from the following equations.

$$
\begin{aligned}
\alpha_{i} & =\alpha_{i}^{*}-m_{i} X\left(P_{i}-P_{i}^{*}\right) \\
V_{i} & =V_{r i}^{*}-n_{i} X\left(Q_{i}-Q_{i}^{*}\right)
\end{aligned}
$$
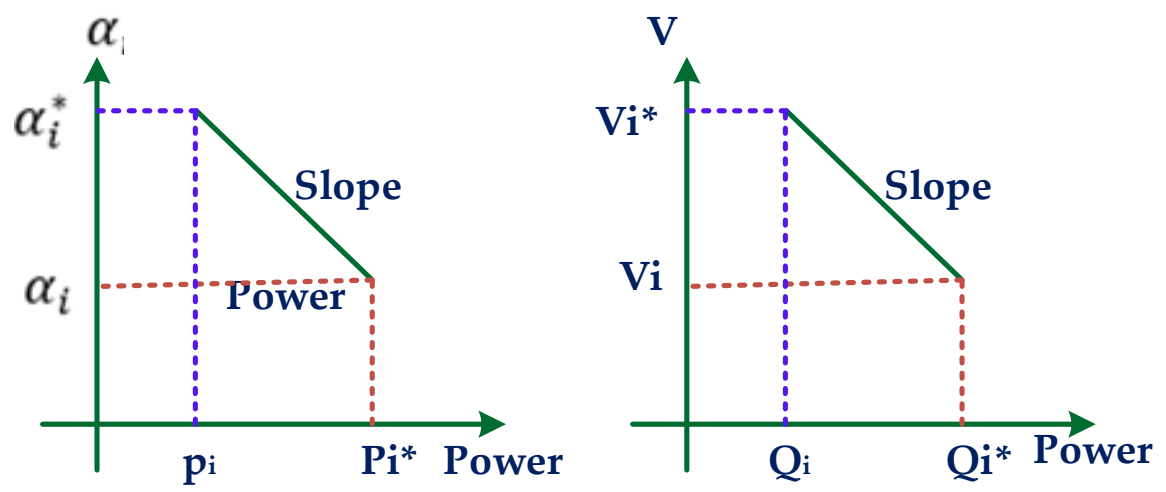

Figure 15. Angle and voltage control characteristics.

$V$ and $\alpha_{i}$ are the measured values when DG supplies the reactive power of $Q$ and real power of $P$ [101]. The main drawback of this control strategy is that it requires a communication channel for angle referencing.

\subsubsection{Communication-Based Control}

In the power-sharing method, the central controller controls the voltage source inverter. There are different types of power-sharing methods used in the centralized control method, such as central sharing, master slave, and distributed sharing [102]. The DC bus voltage is regulated through a multi-loop control in the first method, and the second method operates in master slave mode [103-105]. The performance of the power sharing depends on the master control; transient time is the main drawback in this method. In order to improve reliability, smart charging is used through distributed control.

A comparison of hybrid microgrid charging stations' architecture and control are presented in Table 7. 
Table 7. Comparison of hybrid microgrid charging stations' architecture and control.

\begin{tabular}{|c|c|c|c|c|}
\hline Reference & Renewables & Microgrid Control & ESU Capacity & Load Control \\
\hline [75] & $\mathrm{PV}$, wind & Power-based, rule-based control & Battery & Electromagnetic transient program \\
\hline [106] & PV & $\begin{array}{l}\text { Coordinated rule-based control with } \\
\text { P\&O MPPT }\end{array}$ & $250 \mathrm{~kW}$ & $\begin{array}{l}\text { The direct torque (DTC) and direct } \\
\text { power control (DPC) }\end{array}$ \\
\hline [107] & PV, wind & $\begin{array}{l}\text { Wavelet Transform and Fuzzy } \\
\text { Control-based microgrid control. }\end{array}$ & - & $\begin{array}{l}\text { The fuzzy control is adopted to } \\
\text { optimize the energy management } \\
\text { control of EVs }\end{array}$ \\
\hline [108] & $\begin{array}{l}\text { PV, wind, supercapacitor, } \\
\text { and fuel cell }\end{array}$ & $\begin{array}{l}\text { Pulse width modulation (PWM)-based } \\
\text { power factor correction (PFC) control }\end{array}$ & - & $\begin{array}{l}\text { Constant voltage and constant current } \\
\text { control method }\end{array}$ \\
\hline [109] & PV & $\begin{array}{l}\text { Hybridization algorithm of Particle } \\
\text { Swarm Optimization (PSO) and } \\
\text { Applied Artificial Physics (APO) }\end{array}$ & - & $\begin{array}{l}\text { Voltage control loop (VCL) and current } \\
\text { control loop (CCL) }\end{array}$ \\
\hline
\end{tabular}

In hybrid microgrid management and control strategy, the control is based on a hierarchical control structure: primary, secondary, and tertiary. Mostly three levels of control are used for primary control, including droop-based techniques, which are most suitable for scalable hybrid microgrids. They can provide high plug-and-play capabilities while ensuring adequate power-sharing of devices [100]. The next level's techniques are distinguished depending on whether they are centralized or decentralized. On evaluating studies found in the literature, it was determined that centralized strategies are more adequate at a single-user low scale.

\subsection{Multiport Converter with DC Grid Interconnection}

A multiport converter for the charging operation mode is used for different sources and loads [110]. Based on the requirements, connecting points are designed as bidirectional or unidirectional converters [111]. In addition, when there is more PV power generation, the excess power is fed back to the utility grid by using the same multiport converter. Figure 16 shows multiport charging architecture with DC bus interconnection with DC/DC and DC/AC converters for PV panels, EV, and the grid.

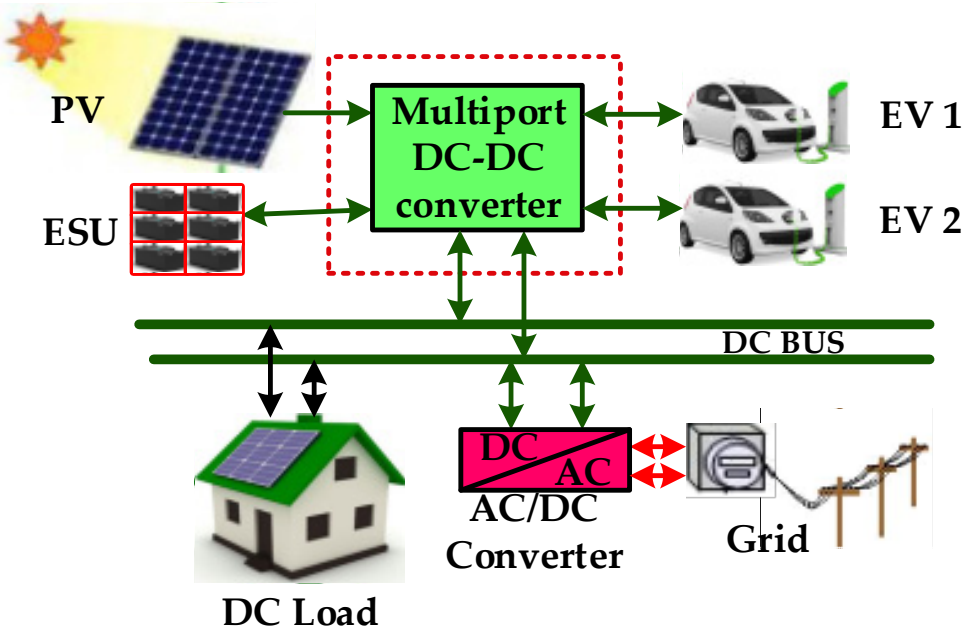

Figure 16. Multiport converter used for charging stations in a DC microgrid.

Different ratings of sources and batteries are connected through a multiport converter. Multiport converters are designed with DC interconnection, facilitating the direct use of DC power for EV charging from DC sources. The PV side DC/DC boost converter can be controlled with the MPPT control technique [112]. Even if direct DC power is available at the DC interconnection, there is a requirement for fast charging, which can be achieved through the converter control. The converter is used to interface EV loads, 
which are unidirectional or bidirectional based on requirement. When the charging side is bidirectional, this can be operated in both buck and boost mode [113]. While charging, the converter works as a buck converter; it increases the current limit for charging and overall control; comparisons are shown in Table 8.

Table 8. Comparison of multiport converter-based charging stations' architecture.

\begin{tabular}{cccccc}
\hline Ref. & Renewables & Microgrid Control & Type of EV Connected & ESU Capacity & Load Control \\
\hline$[114]$ & PV & $\begin{array}{c}\text { Power balance control } \\
\text { using the state diagram } \\
\text { method }\end{array}$ & EV & - & $\begin{array}{c}\text { This involves DC-based charging with } \\
\text { Chademo and the Combined } \\
\text { Charging Standard (CCS). }\end{array}$ \\
\hline$[115]$ & PV & $\begin{array}{c}\text { DC link voltage-based } \\
\text { converter control }\end{array}$ & EV & $2 \mathrm{~kW}$ & PI control of charging point \\
\hline$[29]$ & - & $\begin{array}{c}\text { PWM-based bidirectional } \\
\text { converter control }\end{array}$ & Battery storage & $2.16 \mathrm{kWh}$ & $\begin{array}{c}\text { Inductively coupled power transfer } \\
\text { (ICPT)-based pulse charging }\end{array}$ \\
\hline$[116]$ & $\mathrm{PV}$ & MPPT controller & Battery storage & - & $\begin{array}{c}\text { Different operating modes manage } \\
\text { the charging }\end{array}$ \\
\hline$[117]$ & $\mathrm{PV}$ & PWM control & Battery Bank & - & $\begin{array}{c}\text { Conventional current hysteresis } \\
\text { control method }\end{array}$ \\
\hline
\end{tabular}

Due to its flexibility, a multiport converter has several advantages. It can be used with renewable-energy sources for uninterrupted power supply without storage, or for storage of energy-using hybrid sources in electric vehicles. However, the power capacities of the multiport converters are limited.

\subsection{Multiport Converter with AC Grid Interconnection}

The architecture represented in Figure 17 uses a multiport converter with the AC bus connection. Integration of different sources and loads through a multiport converter leads to a reduction in components counts and increases in power density [118]. This type of charging station architecture is more suitable when the charging station depends more on the utility grid [119]. The disadvantage of this topology is that when different multiport converters are connected to the AC grid, it requires AC-DC conversion.

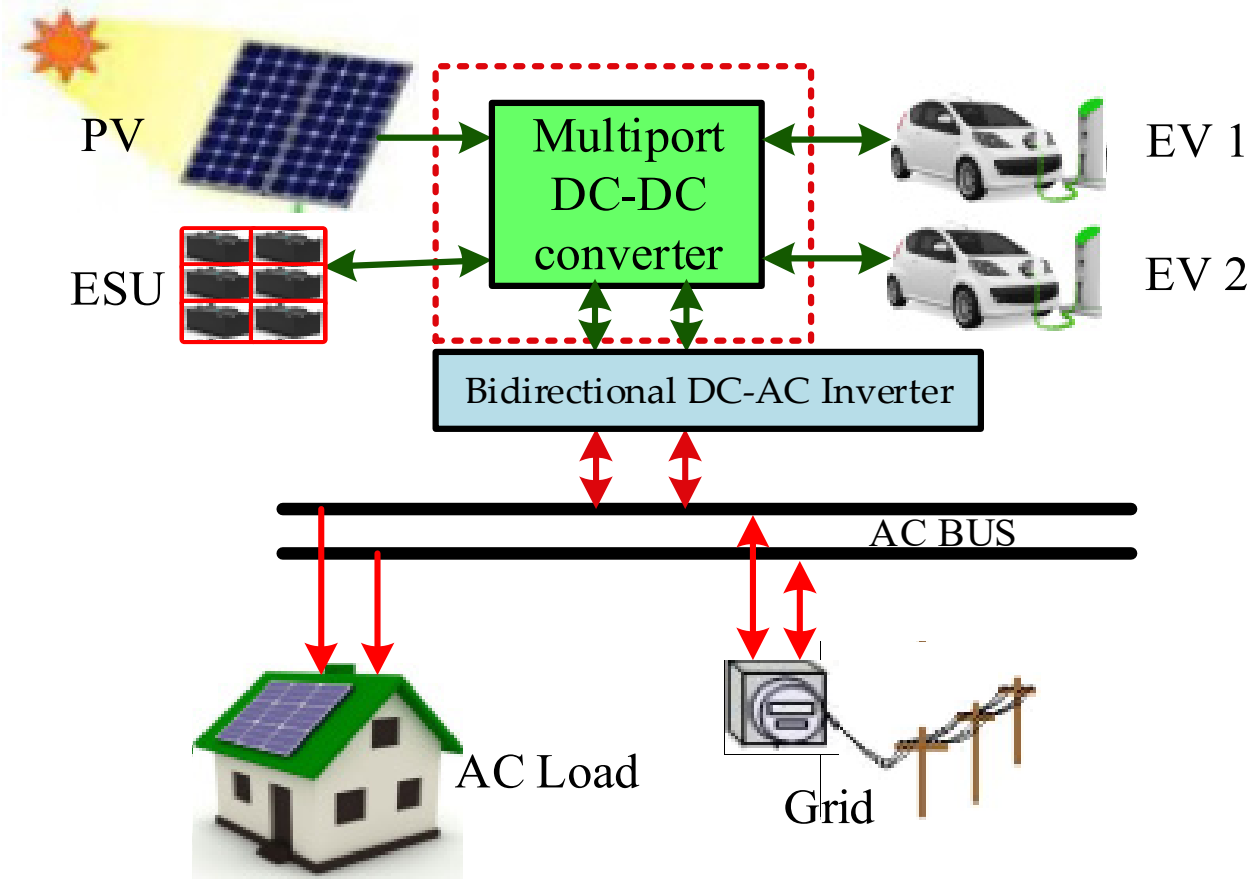

Figure 17. Multiport converter-based AC microgrid. 
This charging station's control is the same as the DC bus-based control, only it differs in the number of multiport converters connected to the AC bus [120]. This architecture uses a communication-based control through the direct connection of a multiport converter. Comparison of the architecture of different multiport converter-based AC microgrid charging stations is presented in Table 9.

Table 9. Comparison of the architecture of different multiport converter-based AC microgrid charging stations.

\begin{tabular}{cccccc}
\hline Reference & Renewables & Microgrid Control & Type of EV Connected & ESU Capacity & Load Control \\
\hline$[91]$ & PV & $\begin{array}{c}\text { Rule-based control with } \\
\text { PSO-based microgrid control }\end{array}$ & EV1 & $150 \mathrm{~kW}$ & SOC-based charging control \\
\hline$[121]$ & - & $\begin{array}{c}\text { The power flow to all the port is } \\
\text { connected through the high } \\
\text { frequency link transformer }\end{array}$ & EV1 & $5 \mathrm{~kW}$ & $\begin{array}{c}\text { PWM-based control strategy used } \\
\text { for EV charging by controlling } \\
\text { gate pulse. }\end{array}$ \\
\hline$[122]$ & PV & MPPT control & - & $10 \mathrm{~kW}$ & PWM-based control strategy \\
\hline$[123]$ & PV & MPPT control & - & $3.3 \mathrm{~kW}$ & Current sharing algorithm. \\
\hline$[124]$ & PV & Power flow & - & - & Rule-based control \\
\hline
\end{tabular}

This multiport converter is gaining interest in the research community by connecting various renewable energy sources along with storage elements to the load/grid [86,124]. A comparison of partially isolated converters was done in terms of component count, ZVS performance, power transfer efficiency, and control strategies. The general operation of the converters is also reported briefly. The different architectures presented in the literature are compared and presented in Table 10. The different criteria influencing the selection of charging stations are environment, economic, society, and technology. Under these different criteria, the sub-criteria for selecting charging stations are environmental factors, waste discharge, and type of landscape. Under the economic factor, the selection of charging stations includes construction cost, annual profit, and maintenance cost. Social factors affecting the charging stations are accessibility, population density, etc. The technological criteria for selecting charging stations are the level of charging, types of charging, number of charging terminals, and types of connectors. Different considerations to be followed to charge an EV without loading the microgrid are charging characteristics, charging time, and types of charging. The power quality of the microgrid is affected due to power regulation, reactive power compensation, load balancing, and filtering of current harmonics. In addition, the control and management of different charging stations and standards and levels are also followed.

Table 10. The comparisons of the hardware topology presented in this paper from different points of view $[53,87,88,103]$.

\begin{tabular}{|c|c|c|c|c|c|c|c|}
\hline Microgrid Architecture & $\begin{array}{l}\text { Isolated DC } \\
\text { Microgrid }\end{array}$ & $\begin{array}{c}\text { Grid } \\
\text { Connected } \\
\text { RES Powered } \\
\text { DC Microgrid }\end{array}$ & $\begin{array}{l}\text { DC Microgrid } \\
\text { with Direct } \\
\text { Connections of } \\
\text { ESU }\end{array}$ & $\begin{array}{c}\text { AC Bus } \\
\text { Charging } \\
\text { Station } \\
\text { Architecture }\end{array}$ & $\begin{array}{l}\text { Hybrid } \\
\text { AC-DC } \\
\text { Microgrid }\end{array}$ & $\begin{array}{c}\text { Multiport } \\
\text { Converter with } \\
\text { DC Grid } \\
\text { Interconnection }\end{array}$ & $\begin{array}{l}\text { Multiport Converter } \\
\text { with AC Grid } \\
\text { Interconnection Grid }\end{array}$ \\
\hline $\begin{array}{l}\text { Direct DC charging (with } \\
\text { no AC conversion) }\end{array}$ & Yes & Yes & Yes & No & Yes & Yes & Yes \\
\hline $\begin{array}{l}\text { Direct AC usage for } \\
\text { local load }\end{array}$ & No & Yes & Yes & Yes & Yes & Yes & Yes \\
\hline $\begin{array}{l}\text { Feasible low amount of } \\
\text { conversion losses during } \\
\text { V2Any (Vehicle and Grid) }\end{array}$ & Yes & Yes & Yes & No & No & Yes & Yes \\
\hline $\begin{array}{l}\text { Fast charging and } \\
\text { discharging of ESU }\end{array}$ & Yes & Yes & No & No & Yes & Yes & Yes \\
\hline $\begin{array}{l}\text { Used for high power } \\
\text { rating }\end{array}$ & Yes & Yes & Yes & Yes & Yes & No & No \\
\hline Reliability & Medium & High & High & Low & Low & Medium & Medium \\
\hline Scalability & Medium & High & Medium & High & Low & Medium & Medium \\
\hline Stability & Stable & Stable & Stable & Stable & Unstable & Stable & Stable \\
\hline
\end{tabular}




\section{Charging Station Standards and Levels}

Charging stations are developed based on different standards and defined by the Society of Automotive Engineers (SAE), based on charging cords and chargers [125]. The International Electro Technical Commission IEC 61851 and American standard SAEJ1772 are two standards defining the communication protocol, electrical, and physical parameters [126]. EV rectification and constant voltage regulations should follow SAE J1772 [127]. In case of utility or microgrid-based charging using off-board chargers, the standards defined by the SAWJ2293 are followed. Communication requirements for integrating systems follow SAEJ 2836 [128]. The different standards followed in charging stations and their scope of a particular standard and type of charging is presented in Table 11.

Table 11. Standards of EV charging [125-128].

\begin{tabular}{|c|c|c|c|}
\hline Standard & Scope & Type & Year \\
\hline SAE J1772 & Define connectors for $\mathrm{AC}$ charging & Conductive & 2010 \\
\hline SAE J2293-2 & $\begin{array}{l}\text { Communication network between electric vehicle supply } \\
\text { equipment (EVSE) and EV; this communication follows an } \\
\text { Enhanced Transmission Selection (ETS) network. }\end{array}$ & Conductive & 2014 \\
\hline SAE J2847-1 & $\begin{array}{l}\text { Provides standard communication between the utility } \\
\text { grid and plug-in electric vehicles. }\end{array}$ & Conductive & 2010 \\
\hline SAE J2847-2 & $\begin{array}{l}\text { This standard defines an off-board conductive DC charger } \\
\text { and its communication with plug-in electric vehicles. }\end{array}$ & $\begin{array}{l}\text { Conductive and } \\
\text { Inductive }\end{array}$ & 2015 \\
\hline SAE J2954 & $\begin{array}{c}\text { This defines a wireless power transfer of all types of } \\
\text { plug-in electric vehicles and its coil alignment } \\
\text { methodology }\end{array}$ & Inductive & 2020 \\
\hline IEC 61980-3 & $\begin{array}{l}\text { Defines the magnetic field-based wireless power system } \\
\text { and its specific requirements. }\end{array}$ & Inductive & 2019 \\
\hline IEC TS 62840-1 & Gives a general overview for battery swap systems & $\begin{array}{c}\text { Battery } \\
\text { swapping }\end{array}$ & 2016 \\
\hline IEC 61851-1 & $\begin{array}{c}\text { Defines EVSE when it is charging from the voltage range } \\
\text { of } 1000 \mathrm{~V} \text { to } 1500 \mathrm{~V} \text { AC or DC, including on-board } \\
\text { rechargeable energy storage systems (RESS) }\end{array}$ & Conductive & 2017 \\
\hline IEC 61851-21-1 & $\begin{array}{l}\text { Defines requirements for conductive connection of an } \\
\text { electric vehicle (EV) to an AC or DC supply }\end{array}$ & Conductive & 2017 \\
\hline IEC 61851-24 & $\begin{array}{l}\text { Defines a digital communication between a DC charging } \\
\text { station and an EV }\end{array}$ & Conductive & 2014 \\
\hline IEC 60364 & $\begin{array}{l}\text { Describes power generation and distribution of electrical } \\
\text { charging station installations in buildings }\end{array}$ & $\begin{array}{l}\text { Conductive } \\
\text { \&Inductive }\end{array}$ & 2017 \\
\hline IEE2030.1.1-2015 & DC quick charger for use with electric vehicles & Fast charging & 2016 \\
\hline GB/T 29317 & $\begin{array}{c}\text { The terminology of electric vehicle charging/battery swap } \\
\text { infrastructure }\end{array}$ & $\begin{array}{l}\text { Battery } \\
\text { swapping }\end{array}$ & 2012 \\
\hline
\end{tabular}

The EV charging station follows three voltage levels; the corresponding power rating is shown in Table 3. Levels 1 and 2 mostly defines on-board charging and level 3 defines off-board charging, most of the microgrid-based level 3 charging employed in the public sector. The levels of charging stations are selected based on the power level of the local grid. The different level-based charging station connectors are shown in Figure 18. Considering the voltage level, EV chargers are classified into three types, namely, DC level $1(200-450 \mathrm{~V}$, $80 \mathrm{~A}$ up to $36 \mathrm{~kW})$, level 2 (200-450 V, $200 \mathrm{~A}$ up to $90 \mathrm{~kW})$, and level $3(200-600 \mathrm{~V}, 400 \mathrm{~A}$ up to $240 \mathrm{~kW}$ ) is presented in Table 12 [129]. The charging power levels of the charging station decide the charging cost, charging time, electric vehicle charging station equipment (EVSE), and usage of the utility grid. 


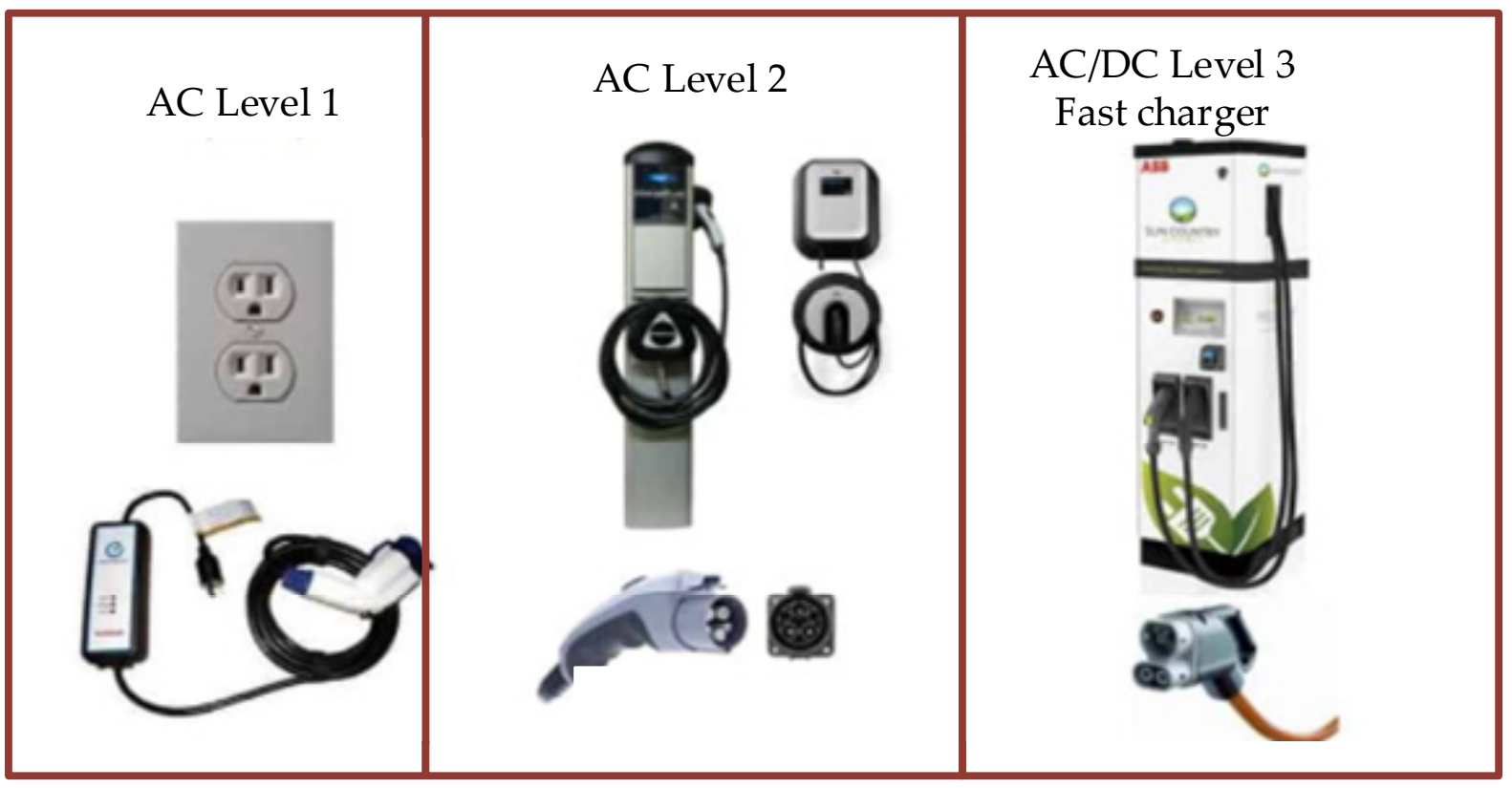

Figure 18. Voltage type level-based EV charging.

Table 12. Levels of charging stations.

\begin{tabular}{|c|c|c|c|c|c|c|c|}
\hline Levels & $\begin{array}{l}\text { Supply } \\
\text { Type }\end{array}$ & $\begin{array}{l}\text { Voltage } \\
\text { Range }\end{array}$ & $\begin{array}{l}\text { Current } \\
\text { Range }\end{array}$ & $\begin{array}{l}\text { Power } \\
\text { Output }\end{array}$ & $\begin{array}{c}\text { PEV } \\
\text { Charging Time }\end{array}$ & $\begin{array}{l}\text { Types of } \\
\text { Chargers }\end{array}$ & EV Connector \\
\hline AC Level 1 & Single phase AC & $\begin{array}{l}120 \mathrm{~V} \\
240 \mathrm{~V}\end{array}$ & $\begin{array}{c}16 \mathrm{~A} \\
13-16 \mathrm{~A}\end{array}$ & $\begin{array}{c}1.9 \mathrm{~kW} \\
3 \mathrm{~kW}\end{array}$ & $7 \mathrm{~h}$ & On-board & $\mathrm{J} 1772^{\mathrm{TM}} / \mathrm{AC}$ \\
\hline AC Level 2 & $\begin{array}{l}\text { Single/three phase } \\
\text { AC }\end{array}$ & $208-240 \mathrm{~V}$ & $80 \mathrm{~A}$ & $20 \mathrm{~kW}$ & $3 \mathrm{~h}$ & On-board & $\mathrm{J} 1772^{\mathrm{TM}} / \mathrm{AC}$ \\
\hline AC Level 3 & $\begin{array}{c}\text { three phase } \\
\text { AC/Como charging }\end{array}$ & $300-600 \mathrm{~V}$ & 400 A max & $120-240 \mathrm{~kW}$ & $30 \mathrm{~min}$ & On-board & CHAdeMO \\
\hline DC Level 1 & $\mathrm{DC}$ & $200-500 \mathrm{~V}$ & $<80 \mathrm{~A}$ & $40 \mathrm{~kW}$ & $22 \mathrm{~min}$ & Off-board & $\mathrm{J} 1772^{\mathrm{TM}} / \mathrm{AC}$ \\
\hline DC Level 2 & DC & $200-500 \mathrm{~V}$ & $<200 \mathrm{~A}$ & $100 \mathrm{~kW}$ & $10 \mathrm{~min}$ & Off-board & $\begin{array}{l}\text { CHAdeMO/DC } \\
\text { SAE/DC }\end{array}$ \\
\hline DC Level 3 & DC & $200-600 \mathrm{~V}$ & $<400 \mathrm{~A}$ & $240 \mathrm{~kW}$ & $30 \mathrm{~min}$ & Off-board & $\begin{array}{l}\text { CHAdeMO/DC } \\
\text { SAE/DC }\end{array}$ \\
\hline
\end{tabular}

\section{EV Charging Connectors}

Standardization of EV charging connectors is required to provide safe and efficient charging. Charging connectors follow the standards of SAE, IEC, and IEEE [126-128]. Different types of standards are defined by different countries, and connectors are not only used for power transfer, but also for communication and sensing. Charging connectors provide the details of the electricity consumed by the connected vehicle. Different charging connectors are used for $\mathrm{AC}$ and DC charging, also based on the levels of charging connector types.

The charging characteristics and requirements of EV-charging differ based on the types of vehicle and capacity of the battery. The charging range of the battery is calculated as the percentage of SOC. The range of SOC in $20-30 \%$ is taken as low and $80-90 \%$ as high value. The charging time of the battery depends on the battery capacity, battery type, and charging level [86]. The charging strategy has two categories-constant current (CC) charging and constant voltage (CV) charging. The battery can be effectively charged with either of these strategies. Sometimes, both strategies are used. Most EVs depend on lithium-ion battery technology, which uses CC followed by CV charging. During CC charging, the current is regulated till the cell voltage reaches the threshold level. Then, the 
charging is done with $\mathrm{CV}$ charging. The specifications of different EV charging connectors are shown in Figure 19. The different types of charging connectors used for EV-charging, based on the supply system and countries, follow different standards [130,131]. Different types of connectors are shown in Figures 19 and 20.

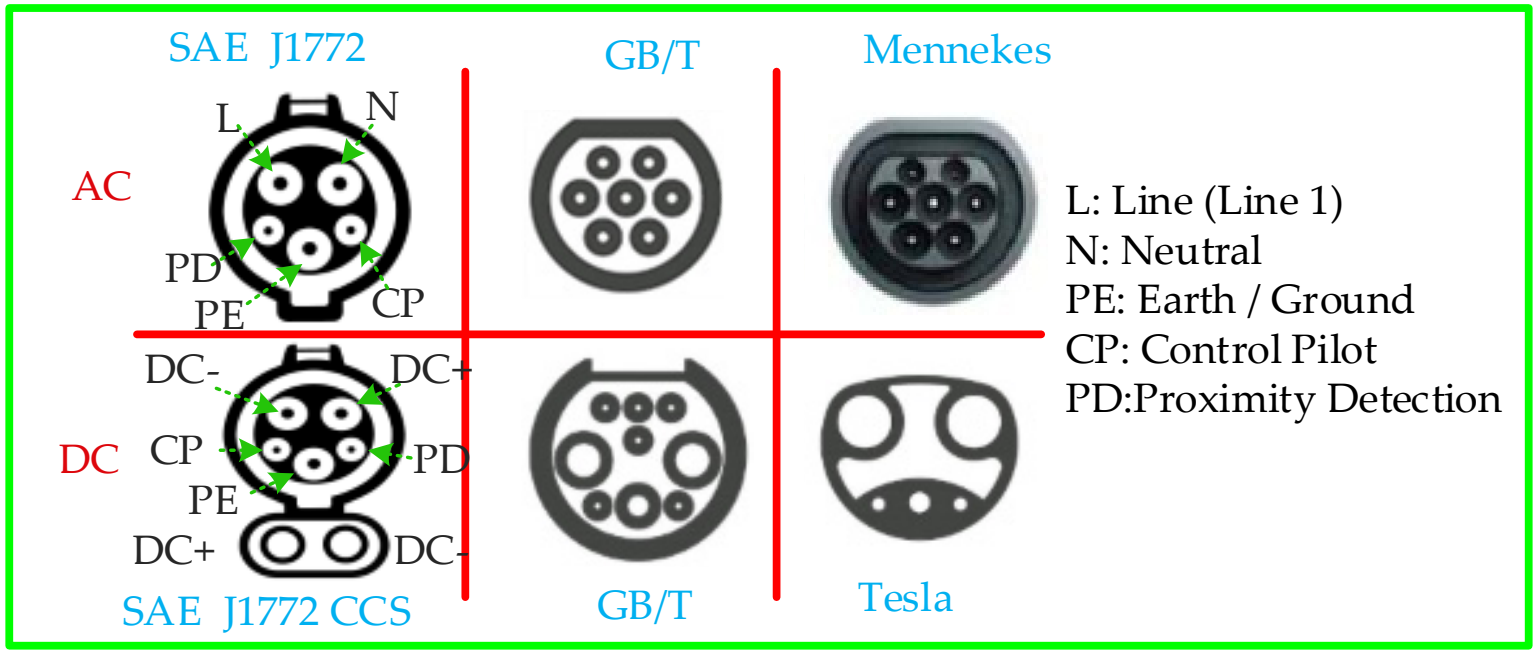

Figure 19. Specifications of different EV charging connectors.

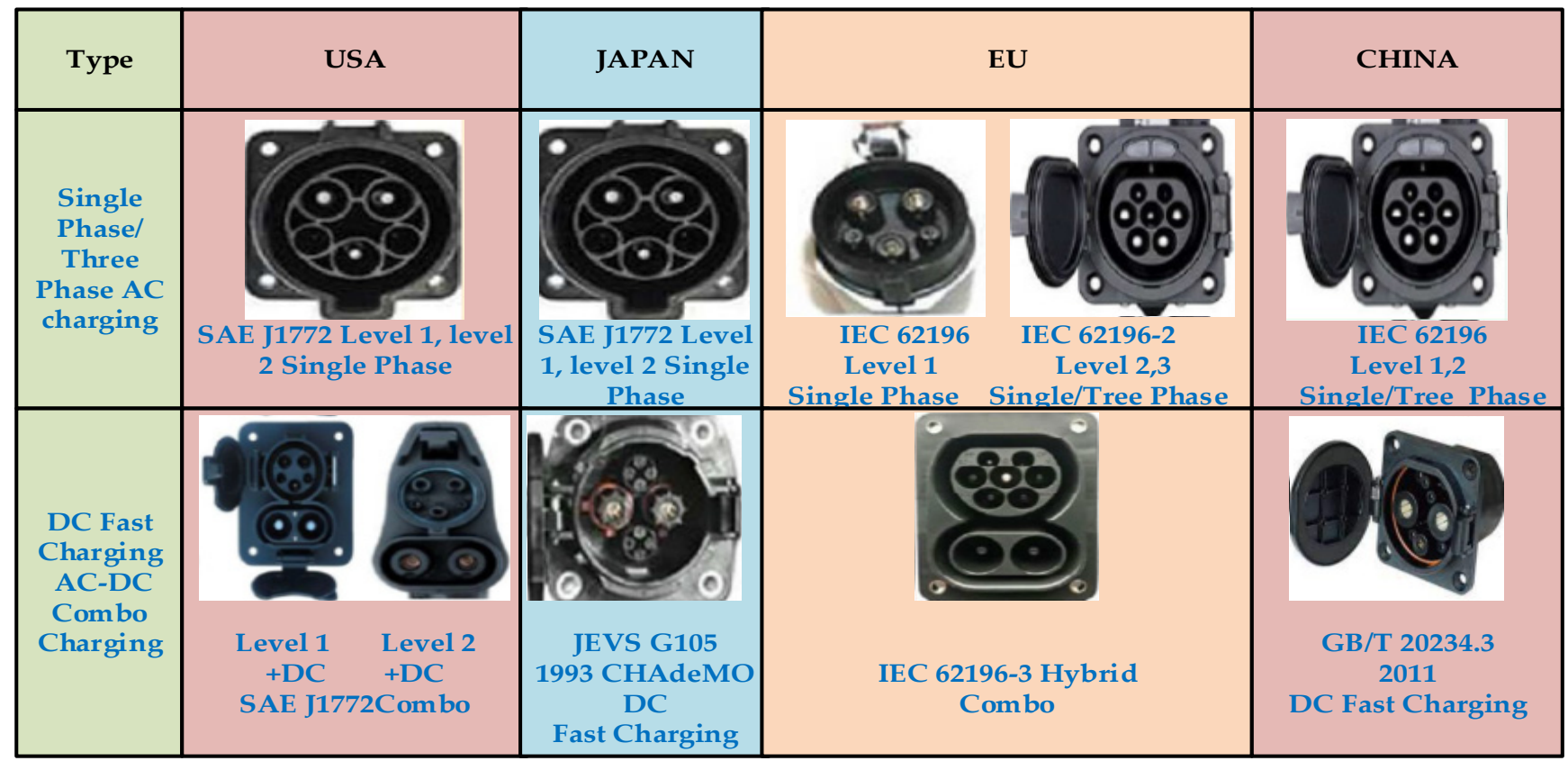

(a)

Figure 20. Cont. 


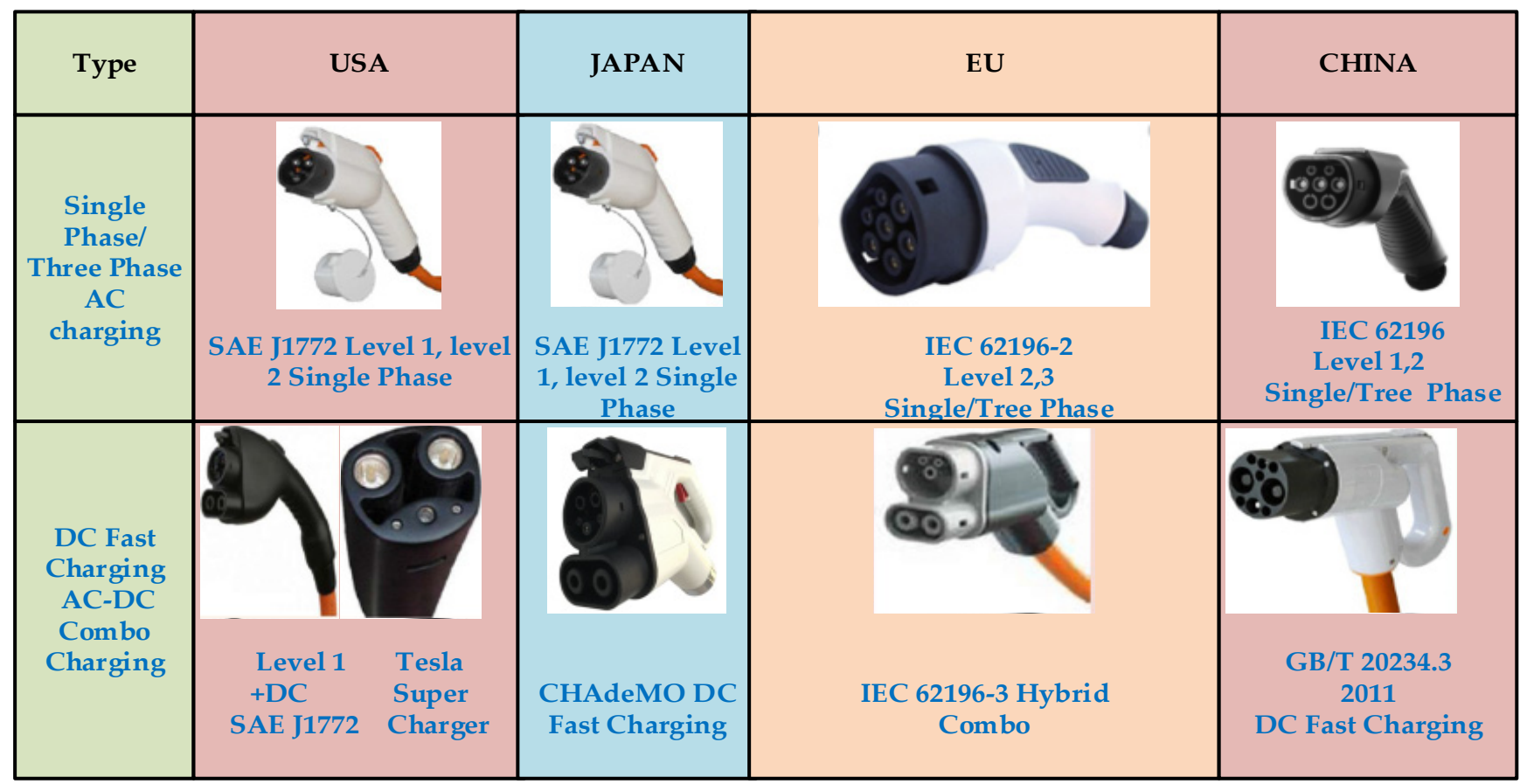

(b)

Figure 20. Types of connectors used in different countries. (a). Male connectors (b). Female connectors.

\section{Power Electronic Converters for Charging Stations}

There are different types of converter topologies used in an EV charging station. Converter types include an AC-AC converter, DC-DC converter, switching-mode inverters, and rectifiers. More DC-DC converters are used in charging stations, classified as unidirectional and bidirectional converters. These converters also work as a cascaded buck-boost converter and operate with low electrical and thermal stress. Moreover, half bridge converters are used because of their high efficiency, but their output current is discontinuous in nature [132]. Bidirectional DC-DC converters are mainly used because they provide regenerative braking in EV and also offer V2G charging. The performance of the converter is increased by reducing the ripples at the output using a switched-capacitor or a combination of a switch and a capacitor. A comparison of traditional converters revealed that those with a minimum number of switches with low voltage stress provide high efficiency [133]. The different types of converter used for EV charging, control scheme and features presented in Tables 13-15.

Power electronic converters, which act as the interface between the grid and the batteries, have the potential to act actively by providing a variety of active functions or ancillary services to support power system operations, such as frequency control, voltage control, operating reserve, controllable load, and power quality (PQ) improvement. This is in the context of the vehicle-to-grid (V2G) concept. Even without a car connected for charging, the AC/DC converter, which includes DC link capacitors, is suitable for use as an active filter in off-board chargers.

\subsection{DC-DC Converters}

The battery in an EV requires a regulated DC supply to efficiently utilize the generated power. Different DC-DC converters connected between the RES and DC bus regulate the output and also provide better control in all parameters to maintain maximum power point [134]. Some applications with bidirectional DC-DC converters are used to maintain power flow in both directions. Generally, bidirectional converters are classified as isolated and non-isolated converters. In an isolated converter, input and output are isolated by using a transformer [110]. 
The charging module connected between the DC bus and the battery controls all the charging parameters. The different DC-DC converters investigated are half bridge, interleaved half bridge, and full bridge with isolation [132]. The half bridge topology is the basic one with a minimum number of components, providing low switching losses. In the basic half bridge converter topology, switching stresses are high. In interleaved converter technology, the ripple generated in the inductor and input current are reduced [135].

The resonant circuit in the converter reduces the switching stress through zero current switching (ZCS) and zero voltage switching (ZVS) [133]. In full bridge, ZVS and ZCS uses soft switching by reducing $\mathrm{di} / \mathrm{dt}$ and $\mathrm{dv} / \mathrm{dt}$ ratios. In full bridge topology, inbuilt isolation transformers are used to provide low switching stress and high efficiency. The basic bidirectional converter operates as a two-quadrant charger, because it operates both in boost and buck mode [133]. The interleaving and resonant topology provides less ripple. The conduction losses and ripple current are controlled by the switches in continuous conduction mode. A dual active bridge (DAB) is used for the EV application due to its ZVS and snubber capacitor. The non-isolated topology is of low cost and the isolated converter is efficient in nature.

\subsection{AC-DC Converters}

The AC-DC converter injects current harmonics into the grid and creates a poor power factor on the grid side; thus, power factor correction is required. In general, the AC-DC converter used in EV charging stations is operated in bidirectional mode. It can also operate as a rectifier and inverting mode.

The AC-DC converters used in the following configurations are basic buck-boost, bridgeless pseudo-boost, and SEPIC [136]. The basic topology uses the diode, which leads to high losses across the diode. The bridgeless pseudo-boost and SEPIC are the modified forms of the converter. Due to electromagnetic emission and high inrush current, SEPIC converters are used. In addition, single phase and three phase converters are also used for EV-charging. However, in most high power charging stations, three-phase full bridge topology is used due to its fewer switching losses. In addition, multi-level topology was also investigated due to its lower voltage stress and switching losses [137]. The three-level flying capacitor multilevel inverter was analyzed and found to provide fixed voltage stress and less DC link voltage. Even though it is of complex topology, it provides better efficiency. The charging infrastructure in India is shown in Figure 21 [138-140].
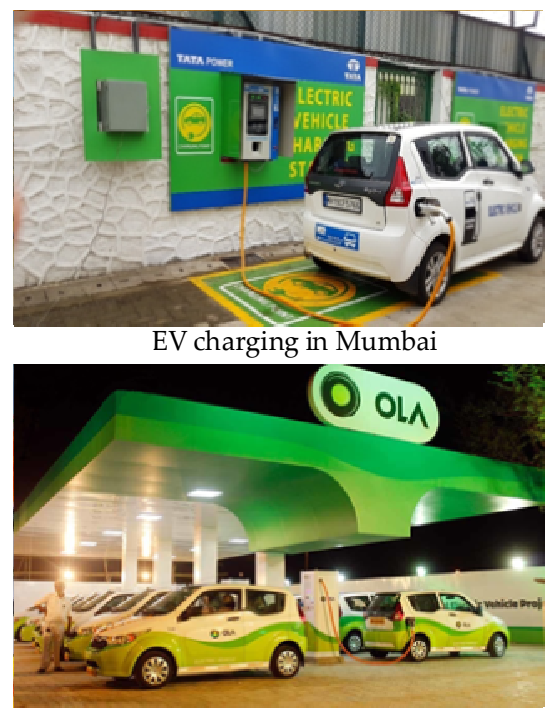

EV charging in Delhi
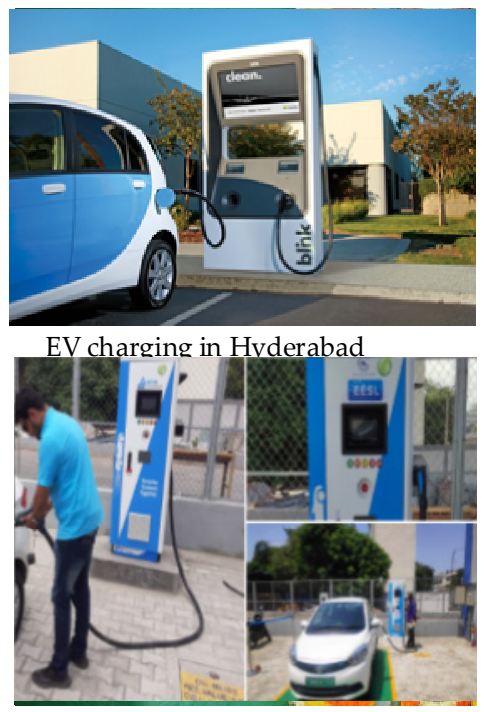

EV charging in Chennai

Figure 21. Charging infrastructure in India. 
There are many factors influencing the selection of converter topology, such as power quality level (permitted level of power factor and THD), type of output (variable or constant), power flow direction (unidirectional or bidirectional), and nature of output (isolated and non-isolated), as shown in Figure 22. Other factors include size, cost, efficiency, reliability, and number of input and output. The main factors considered in the selection are magnetic components and control methodology.

Table 13. Grid side AC-DC converters.

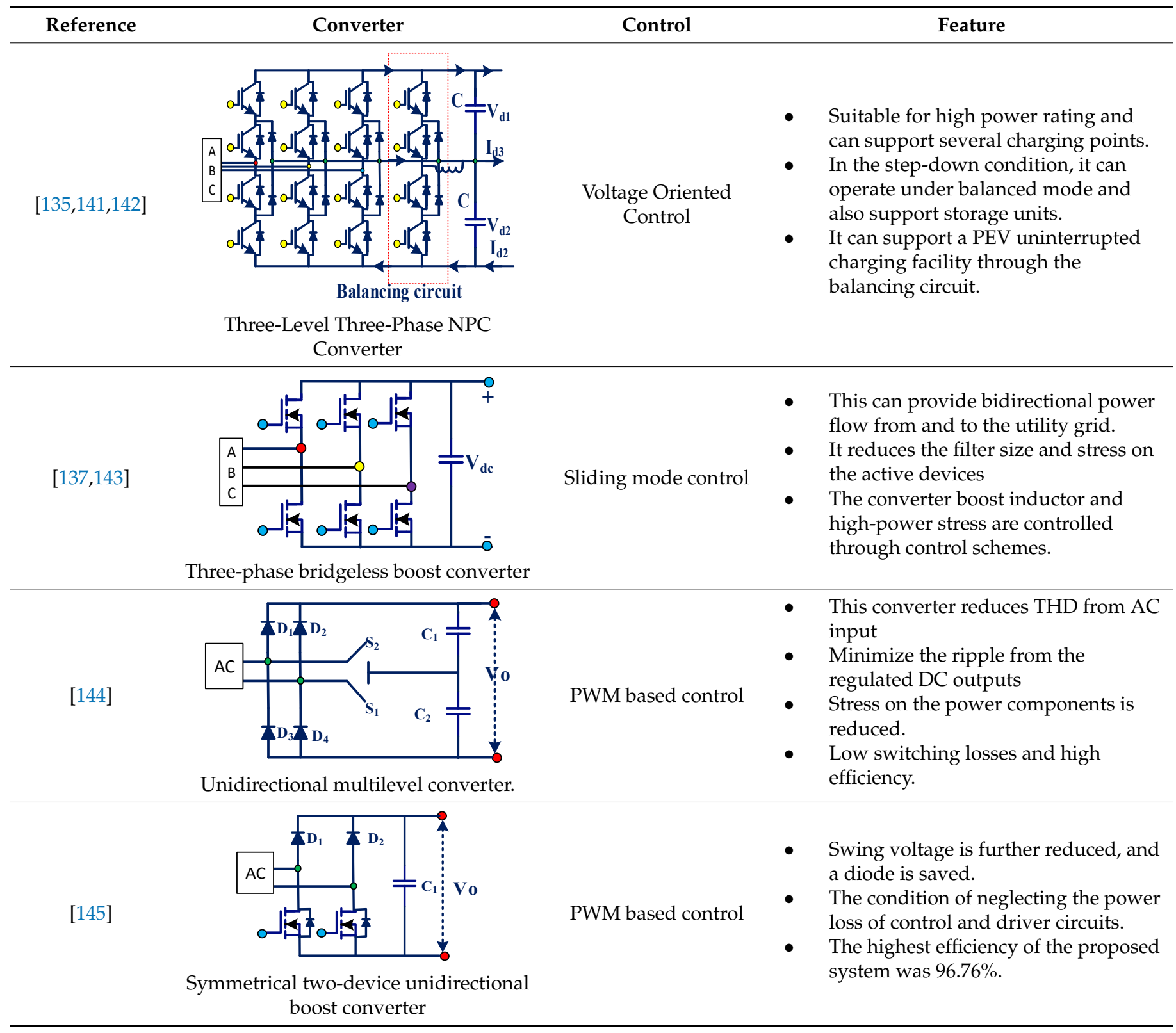


Table 14. PV side DC-DC converters.

\begin{tabular}{lll}
\hline Ref. & Control & Feature \\
\hline 146] & $\begin{array}{l}\text { The control MPPT operated on the basis } \\
\text { of the voltage on the PV output and } \\
\text { weather conditions. } \\
\text { This cuk converter operated under two } \\
\text { loop controls such as voltage and } \\
\text { current control. } \\
\text { The control methodology can track } \\
\text { closely to the DWSSA predicted MPP } \\
\text { voltages with accuracy and minimum } \\
\text { oscillation }\end{array}$ \\
\hline
\end{tabular}

[147]

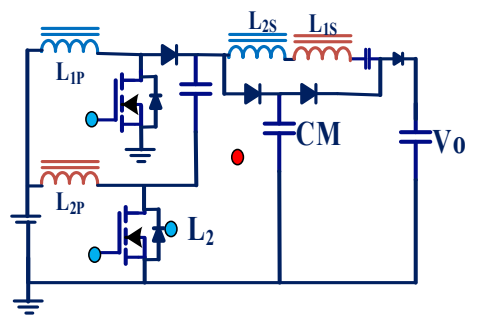

Voltage lift technique

Interleaved high gain DC-DC converter

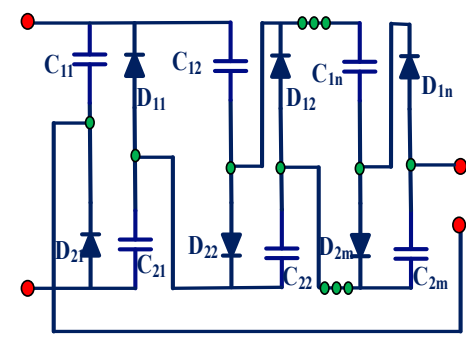

Transformer less high gain boost and buck-boost DC-DC converters
- $\quad$ A DC-DC converter was developed from a two-phase IBC consisting of one $\mathrm{CI}$ in each phase, a voltage lift capacitor Clift, and one VMC network connected across the secondary windings.

- The converter confirmed the delivered power of $225 \mathrm{~W}$ to the load at $91.6 \%$ full load efficiency.

- $\quad$ The SC-based converters attain a creditable position for standalone PV systems operating at a higher voltage level, above $300 \mathrm{~V}$, in comparison to the conventional B-BBCs.

- The structure allows increasing the SC cells in order to obtain the reduced voltage stress on switching components with a higher voltage gain.

- It allows the converter to achieve a higher gain, which is otherwise not possible in conventional converters.

- $\quad$ Provide higher output voltage.

- Output current is continuous and minimizing the switching stress also reduces the ripple in output.

- The converter topology used to attain the maximum power.

Single-Ended Primary Inductance Converter (SEPIC) 
Table 15. Charging side DC-DC converters.

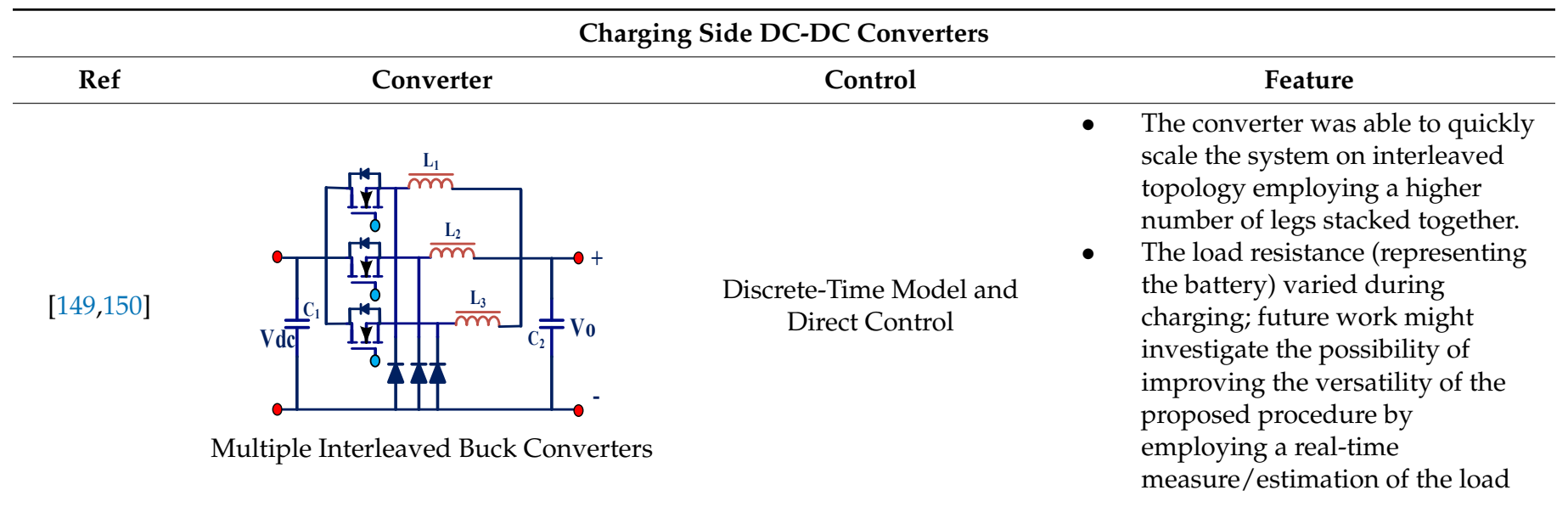

- $\quad$ Fast-charging converter uses soft switching characteristics in the ZVS region

- $\quad$ The EV system has a fast-charging scheme with an LIB of $800 \mathrm{Wh}$ and SC of $50 \mathrm{Wh}$.

[151]

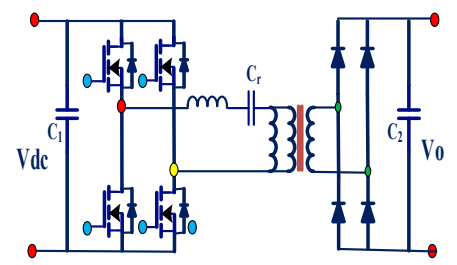

PFM (Pulse Frequency Modulation) and PI control.

Full-Bridge LLC Resonant Converter

\section{[152]}

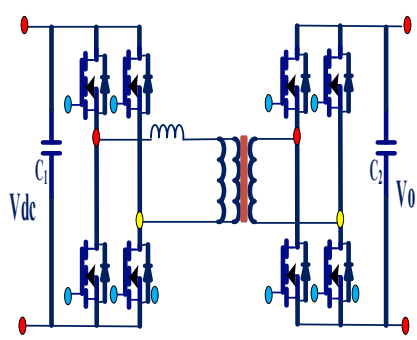

Dual Active Bridge
Current sharing control

e PWM modulation factor value and thereby controls
- The charging time through the fast-charging SC system has a charging time of about $20 \mathrm{~min}$.

- The transient period during the conversion from the CC mode to the $\mathrm{CV}$ mode.

- The maximum conversion efficiency of the output current of $30 \mathrm{~A}$ in the CC mode is $96.4 \%$.

- The converter reduces the charging time and allows for wide LS-EVs adoption.

- $\quad$ The multi-module DC-DC converters for LS-EVs fast chargers are used due to the fact that modular power converters offer easy maintenance, redundancy, and scalability.

- $\quad$ The higher switching frequency can be achieved in the AC link, which results in weight and size reduction.

- $\quad$ The employment of soft switching techniques; losses of the converter are reduced

- The extension of drive FCs to the additional battery charging functionality of EVs and mobile electric work machines allows the distribution of battery charging stations.

- Existing converter electric drives can be adapted for battery charging. 
Table 15. Cont.

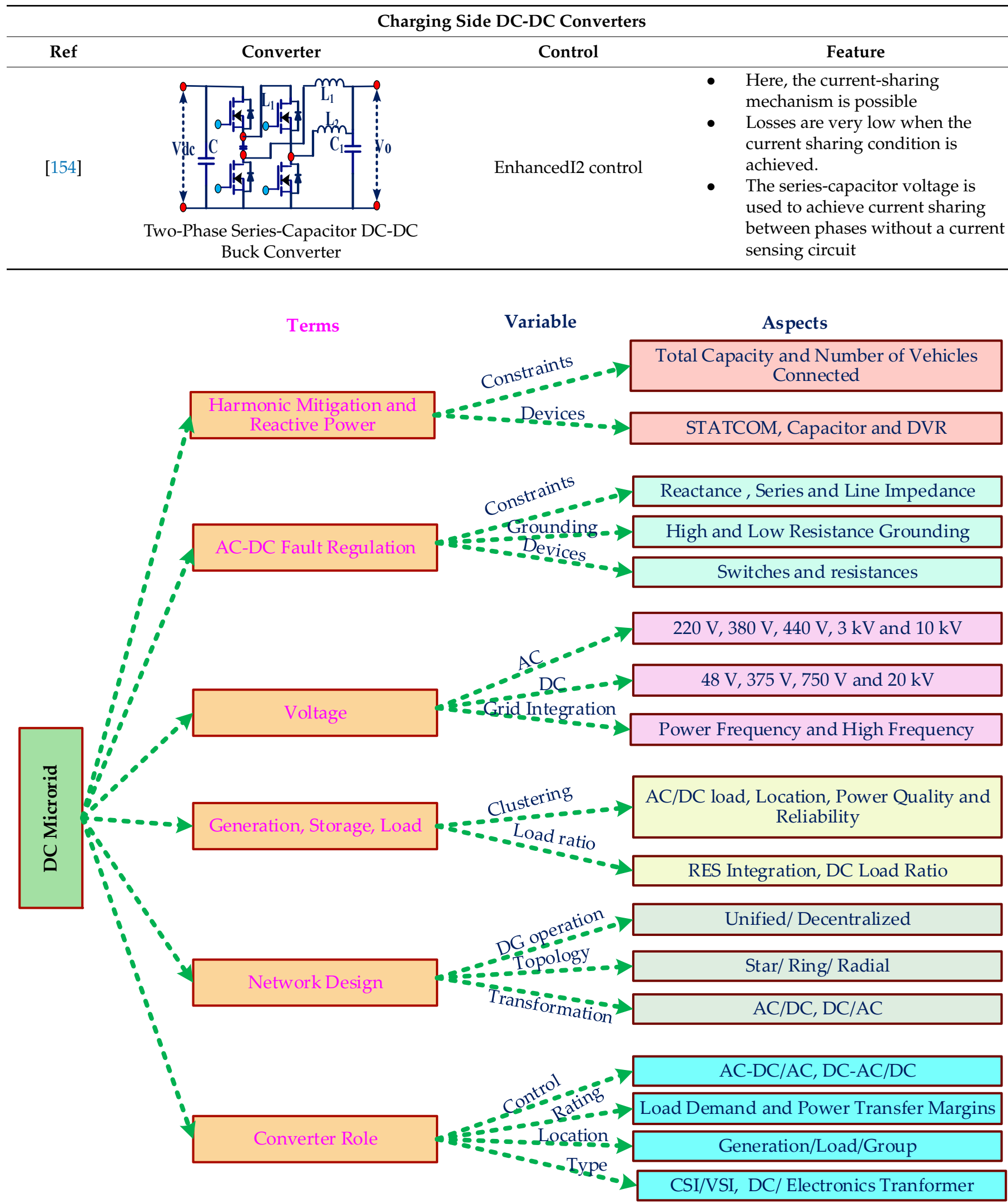

Figure 22. Typical MG system planning requirements. 


\section{Control Strategy of Charging Stations}

A charging station's microgrid voltage is regulated for effective utilization of charge. The optimization algorithm and nonlinear disturbance observer (NDO)-based control provides better voltage regulation along with its filter circuit. This section discusses the various control techniques investigated in the EV charging station control.

\subsection{Rule-Based Control}

Supervisory control improves charging station performance through system control based on engineering knowledge, mathematical model, and predefined power required by the charging port [155]. This rule-based control is operated with a deterministic or fuzzy based method. In the deterministic method, a lookup table-based control is used for the output control; it is not based on real-time data. In addition, it is operated in an on/off-based control strategy. The on/off control strategy is easy and simple; it is based on charging or discharging. Input sources are turned on/off based on the battery parameter SOC and voltage.

\subsection{Fuzzy Logic Control of Charging Stations}

The charging station requires an energy management strategy to control power flow; fuzzy-based optimization provides a better solution for vehicle control [156]. The fuzzybased priority charging or discharging ESU at the charging station is also presented. Peng and Jessy proposed a simulation study for parallel hybrid electric vehicles; it suggests that the fuzzy logic increases fuel economy and fast charging of EV [157]. Better energy management in hybrid vehicles with hybrid energy sources like ultra-capacitor, fuel cells, and battery storage is done through the fuzzy logic system. In addition, split energy management includes a hybrid electric vehicle and a controller used as an auto boxed SPACE platform. A comparison between conventional controllers revealed that a fuzzy logic controller is a suitable tool to control the power converter at the charging station.

The energy management strategy is based on decentralized microgrid voltage control using the fuzzy logic technique [158]. In addition, charging and discharging priority of hybrid source-connected EVs are controlled through fuzzy-based control. Decentralized fuzzy control is used with a coordinated operation between DC bus voltage, power flow, and energy storage device SOC. Based on charging station architecture, power rating of EV, renewable energy sources, and different types of isolation, bidirectional or unidirectional converter comparisons are shown in Table 16.

Table 16. Charging Station Control.

\begin{tabular}{|c|c|c|c|}
\hline Ref. & System Architecture & $\begin{array}{l}\text { Charging Station Control } \\
\text { Strategy }\end{array}$ & $\begin{array}{c}\text { Power Converter Topologies Used and } \\
\text { Control Methodology }\end{array}$ \\
\hline$[159,160]$ & $\begin{array}{l}\text { Isolated DC microgrid for } \\
\text { EV-charging }\end{array}$ & $\begin{array}{l}\text { Rule-based control using power } \\
\text { balancing control, optimal power } \\
\text { self-scheduling of power } \\
\text { balancing control }\end{array}$ & $\begin{array}{c}\text { A dedicated DC-DC converter is used. } \\
\text { Differential evaluation based on SOC } \\
\text { predicted that charging minimizes total } \\
\text { energy cost }\end{array}$ \\
\hline$[86,161,162]$ & $\begin{array}{l}\text { Grid-connected RES powered } \\
\text { DC microgrid for EV-charging }\end{array}$ & $\begin{array}{l}\text { PV-based battery charging } \\
\text { stations considering service } \\
\text { availability, DC link power } \\
\text { predictive model (PPM) for } \\
\text { charging station control }\end{array}$ & $\begin{array}{l}\text { Dual stage-controlled DC-DC converter } \\
\text { along with the optimization algorithm } \\
\text { for charging }\end{array}$ \\
\hline [163] & $\begin{array}{l}\text { RES-powered DC microgrid } \\
\text { with ESU }\end{array}$ & DC link voltage-based control & $\begin{array}{l}\text { Dedicated DC-DC converter for PHEVs } \\
\text { charging; it uses minimum energy from } \\
\text { the utility grid }\end{array}$ \\
\hline$[164,165]$ & $\begin{array}{l}\text { AC bus-coupled charging } \\
\text { station architecture }\end{array}$ & $\begin{array}{c}\text { Control area network (CAN) } \\
\text {-based charging station control }\end{array}$ & $\begin{array}{l}\text { Charging of EV with AC-DC } \\
\text { bidirectional converters; it works in both } \\
\text { inverter and rectifying mode }\end{array}$ \\
\hline
\end{tabular}


Table 16. Cont.

\begin{tabular}{|c|c|c|c|}
\hline Ref. & System Architecture & $\begin{array}{l}\text { Charging Station Control } \\
\text { Strategy }\end{array}$ & $\begin{array}{c}\text { Power Converter Topologies Used and } \\
\text { Control Methodology }\end{array}$ \\
\hline$[166,167]$ & Hybrid AC-DC Microgrid & $\begin{array}{c}\text { Power oscillation damping } \\
\text { control implemented for both } \\
\text { ESU and other devices connected } \\
\text { to the microgrid }\end{array}$ & $\begin{array}{l}\text { SOC-based charging of EV is done based } \\
\text { on DC link voltage and is controlled } \\
\text { through a DC-DC converter. Charging } \\
\text { and discharging of ESU operates inner } \\
\text { current loop control outer } \\
\text { voltage/frequency control }\end{array}$ \\
\hline [168-170] & $\begin{array}{l}\text { Multiport converter-based DC } \\
\text { micro grid }\end{array}$ & $\begin{array}{l}\text { DC bus voltage is maintained } \\
\text { through the PI and fuzzy } \\
\text { controller. }\end{array}$ & $\begin{array}{l}\text { Two loop control of battery charging is } \\
\text { followed as constant current and constant } \\
\text { voltage control }\end{array}$ \\
\hline$[171]$ & $\begin{array}{c}\text { Multiport converter-based AC } \\
\text { micro grid }\end{array}$ & $\begin{array}{l}\text { Dual active bridge-based, } \\
\text { control-based current sharing } \\
\text { error compensation }\end{array}$ & $\begin{array}{l}\text { Dual output port controlled for charging } \\
\text { based on the realized DC voltage }\end{array}$ \\
\hline
\end{tabular}

The design of a charging station with minimum conversion losses between the sources to load provides high efficiency. Charging cords are isolated from the power sources due to safety reasons. Charging stations with ESU provide uninterrupted supply for charging. A bidirectional converter on the vehicle side provides an option for vehicle-to-anything charging.

PV power generation is generally intermittent in nature, which tends to the variation of microgrid voltages. The regulation of microgrid voltage is done by adding available power sources to the DC bus. Direct connection of the battery to the DC microgrid creates fluctuations in DC bus voltage and is controlled by the DC-DC converter. When a largescale signal is applied, the proportional-integral controller is unable to predict the load voltage and increases the rise time and reduces oscillation. A fuzzy logic controller is thus a suitable tool to control the power converter at the charging station. Moreover, it provides coordinated operation between the DC bus voltage and SOC ESU.

\section{Energy Management in DC Microgrid-Based Charging Stations}

DC microgrid-based EV charging stations reduce conversion losses in recent power systems. A microgrid with RES provides effective reduction in emissions; effective utilization is done through the EMS. The development of charging stations with multiport charging terminals creates overloading in the microgrid and utility grid. In addition, multiport charging stations address the following technical issues:

$>$ Development of an energy management strategy to control the power flow among available sources and charging terminals for effective utilization of the generated renewable power.

$>$ In a PV-powered charging station, the power produced by the PV is variable in nature and it creates a DC bus voltage variation in the microgrid, irrespective of overloading and irradiation on the PV.

$>$ The charging port with the closed loop control provides constant current and constant voltage charging, and reduces charging time.

The main motive of the EMS and its control is to maximize the usage of RES consumption. In addition, the energy stored in ESU, when excess power is produced by RES or EV charging ports, is idle.

\subsection{Microgrid-Connected EV Charging Stations}

The EV-charging station's architecture in microgrids is shown in Figure 23. The charging station is connected to a PV system by an MPPT-controlled DC-DC converter [157]. Three charging ports in the station are connected via a bidirectional DC-DC converter. In addition, utility grids are connected to the charging stations by a distribution transformer 
AC-DC bidirectional converter. EV charging stations and local loads are connected with secondary distribution transformers. BMS in the charging station is used to disconnect the vehicle during abnormal conditions. It can increase the safety of the system by monitoring and controlling effective utilization of power input. In addition, BMS predicts the state of health, providing safe and quality operation and performance [172]. Furthermore, IC is designed to be operated by an external BMS control unit via a serial peripheral interface (SPI), through which acquired data can also be retrieved [173].

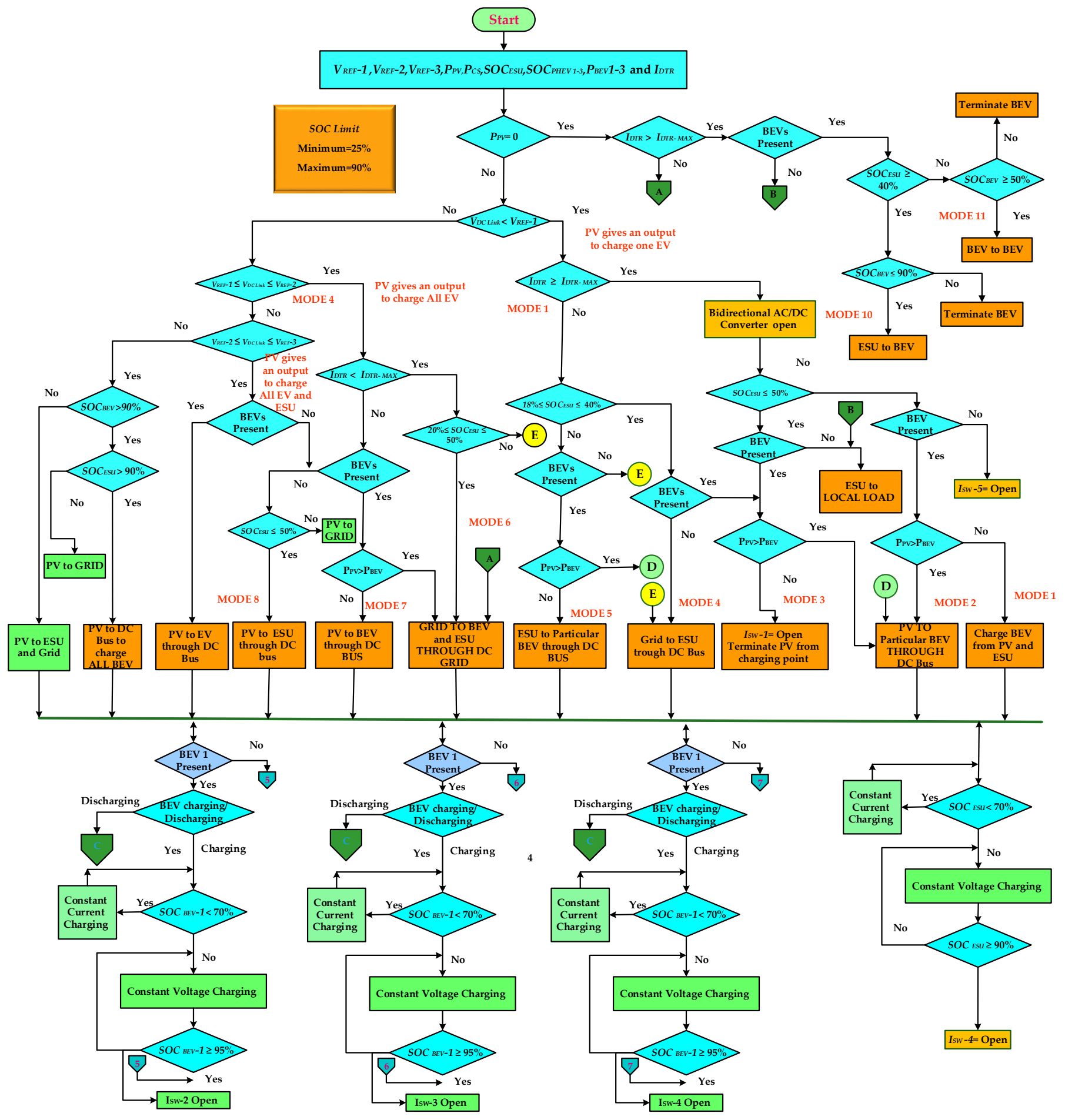

Figure 23. The charging station's EMS flowchart. 


\subsubsection{Energy Management Modes}

The charging stations' operating modes are developed based on renewable source (PV) availability and considered as a prime source. When the utility grid is in peak demand for electricity and PV power is less than or equal to the power capacity of the single charging point, the charging station operates in modes 1 to 4 . These modes' EV charging power is utilized along with other available sources, such as ESU and utility grid shared with all or any EV available at the charging station. The next four modes are operated as PV power, rather than charge for all the EVs available at the charging point. PV power greater than or equal to the storage connected to the charging station as EV and ESU at the charging point can be considered Modes 9 to 11. Based on the above considerations, the charging station operates under 11 different modes, as shown in Figure 23, along with their corresponding considerations.

\subsubsection{Experimental Implementation}

The charging station's architecture and practical feasibility were tested with the help of a laboratory prototype. The energy management strategy and control of $240 \mathrm{~W}$ rating of charging stations was developed. This charging station consisted of three EV ports, one ESU unit, separate inverter circuit for testing utility grid integration, and a PV integrated boost converter; an FPFA controller is used for overall control. The PV is connected to the DC charging system through a MPPT boost converter. The charging port uses a bidirectional DC-DC converter and ESU of $12 \mathrm{~V}, 80$ Ah lead acid battery. The MPPT extracted from the PV is $240 \mathrm{~W}$ during full operating conditions, the corresponding voltage and current measured as $18 \mathrm{~V}$ and $13.34 \mathrm{~A}$. The P\&O with MPPT algorithm was used to attain the maximum power output from the PV system. On comparison with the original system, $5 \%$ losses were considered compared to the lab scale prototype.

The DC bus voltage is varied based on the irradiation over the PV. The experimental modes selected were based on the selection of the threshold value of the PV power. There were three reference power levels selected-low, medium, and high. The values are $\mathrm{P}_{\mathrm{PV} \mathrm{REF} 1}=120 \mathrm{~W}, \mathrm{P}_{\mathrm{PV} \text { REF } 2}=160 \mathrm{~W}$, and $\mathrm{P}_{\mathrm{PV} \mathrm{REF} 3}=230 \mathrm{~W}$, respectively. Based on this, the charging station's operating modes are selected, as explained below.

- $\quad$ Mode 1: ESU and PV to EV charging ( $\left.P_{P V} \leq 120 \mathrm{~W}\right)$.

- Mode 2: Particular EV charging by PV ( $\left.\mathrm{P}_{\mathrm{PV}} \leq 120 \mathrm{~W}\right)$.

- Mode 3: Utility grid and PV-based ESU charging $\left(\mathrm{P}_{\mathrm{PV}} \leq 120 \mathrm{~W}\right)$.

- Mode 4: Utility grid and PV-connected EV charging $\left(\mathrm{P}_{\mathrm{PV}} \leq 120 \mathrm{~W}\right)$.

- Mode 5: Utility grid and PV-powered EV and ESU charging (120 W $\left.\leq \mathrm{P}_{\mathrm{PV}} \leq 160 \mathrm{w}\right)$

- $\quad$ Mode 6: PV-powered EV charging $\left(120 \mathrm{~W} \leq \mathrm{P}_{\mathrm{PV}} \leq 160 \mathrm{~W}\right)$.

- $\quad$ Mode 7: Utility grid powering $\left(120 \mathrm{~W} \leq \mathrm{P}_{\mathrm{PV}} \leq 160 \mathrm{~W}\right)$.

- Mode 8: PV-powered EV and ESU charging $\left(160 \mathrm{~W} \leq \mathrm{P}_{\mathrm{PV}} \leq 230 \mathrm{~W}\right)$.

- $\quad$ Mode 9: PV-powered energy storage $\left(\mathrm{P}_{\mathrm{PV}} \geq 230 \mathrm{~W}\right)$.

- Mode 10: Energy storage to EV charging $\left(\mathrm{P}_{\mathrm{PV}}<\mathrm{P}_{\mathrm{PV} \text { MIN }}\right)$.

- Mode 11: EV to EV (V2V) charging ( $\left.\mathrm{P}_{\mathrm{PV}}<\mathrm{P}_{\mathrm{PV} \text { MIN }}\right)$.

The PV produces less power than or equal to reference level 1, which is not sufficient to charge all the EVs and ESUs at the charging station. This is operated in four different modes (mode 1 to mode 4 ). Among the first four modes, mode 2 and mode 4 are presented for experimental results.

1. Mode 2: Particular EV Charging by PV $\left(\mathrm{P}_{\mathrm{PV}} \leq 120 \mathrm{~W}\right)$

The side bidirectional converter in modes 1 and 2 charging work under buck mode to charge the EV. By considering mode 2, the PV system delivers an output to the particular EV available at the charging point. The different parameters of the charging station monitored under this mode are DC bus power, PV voltage and current, distribution to the local load, and corresponding EV port current, as shown in Figure 24. 


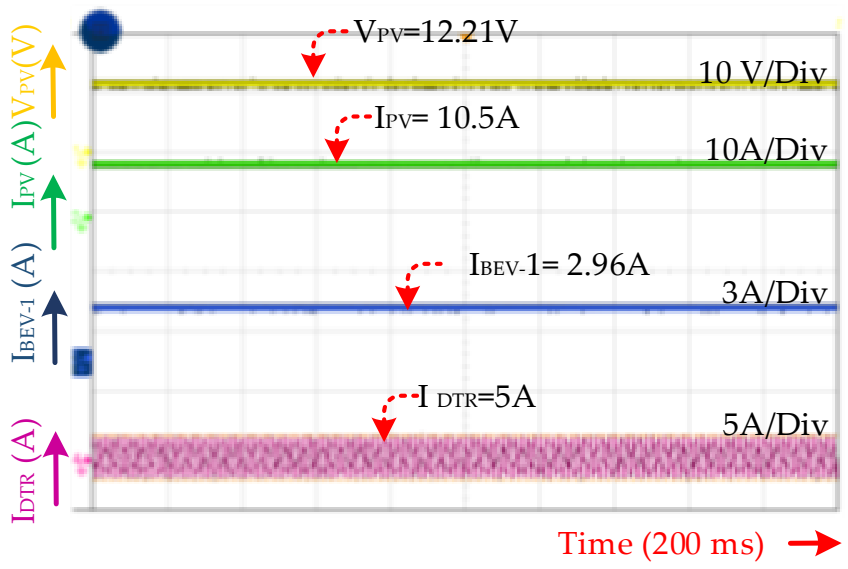

Figure 24. PV to particular EV charging.

Mode 6: PV-powered EV charging $\left(120 \mathrm{~W} \leq \mathrm{P}_{\mathrm{PV}} \leq 160 \mathrm{~W}\right)$. In this mode, the PV delivers the power of $150 \mathrm{~W}(\mathrm{VPV}=13.09 \mathrm{~V}, \mathrm{IPV}=11.53 \mathrm{~A})$. The $\mathrm{DC}$ bus voltage is measured as $22 \mathrm{~V}$ and the bidirectional converter operated in buck mode to charge the EV battery connected to the charging point, as shown in Figure 25.

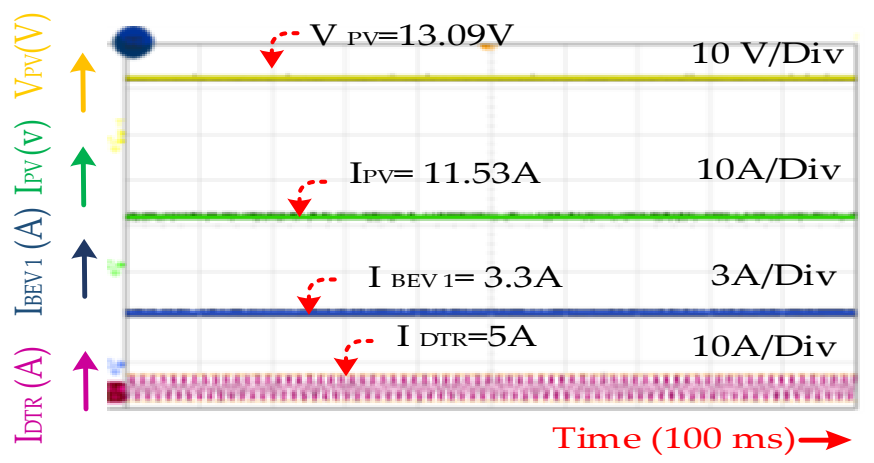

Figure 25. PV-powered EV charging.

2. $\quad$ Mode 9: PV-powered Energy Storage $\left(\mathrm{P}_{\mathrm{PV}} \geq 230 \mathrm{~W}\right)$

In this PV-powered energy storage mode, batteries connected to the charging points are fully charged and the PV voltage and current are measured as $\left(\mathrm{V}_{\mathrm{PV}}=18.1 \mathrm{~V}, \mathrm{I}_{\mathrm{PV}}=12.7 \mathrm{~A}\right)$, as shown in Figure 26.

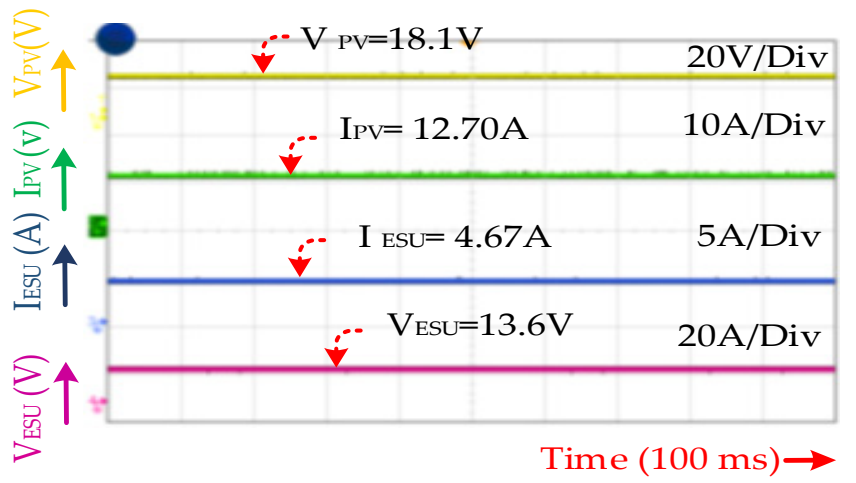

Figure 26. PV-powered energy storage.

3. Mode-11: EV to EV (V2V) Charging ( $\left.\mathrm{P}_{\mathrm{PV}}<\mathrm{P}_{\mathrm{PV} \text { MIN }}\right)$

In this mode, all the sources at the charging station are unable to supply the power for EV-charging; only particular ports allow EV-charging by exchanging power between 
EVs. The power provided in this mode is from one vehicle to the other; the corresponding values are measured as $13.9 \mathrm{~V}, 1.9 \mathrm{~A}$ from the supply vehicle to the charging vehicle, as shown in Figure 27.

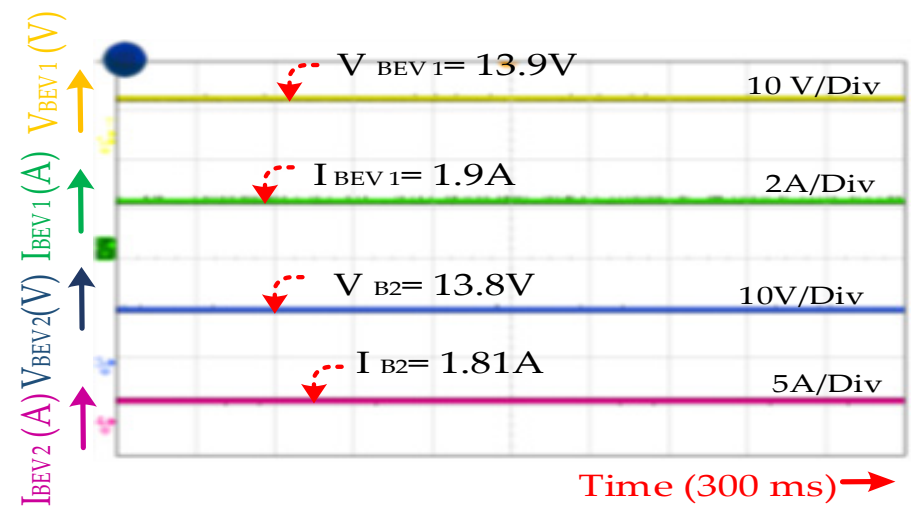

Figure 27. EV-EV (V2V) charging $\left(\mathrm{P}_{\mathrm{PV}}<\mathrm{P}_{\mathrm{PV} \text { MIN }}\right)$.

The main objective of the EMS is to avoid the overloading of distribution transformers, effective usage of renewable energy, and uninterrupted supply for charging. This type of charging architecture is more suitable for workplace-based charging, because the small amount of power generated from the PV is directly utilized by the EV that can accept the power level offered in vehicle-to-vehicle charging. All the modes provide uninterrupted charging based on EV availability through the EMS approach.

The EMS at the charging station maintains DC bus voltage and power requirements for all the conditions of utility grid local load increasing or overloading. The energy management modes in the charging station provide continuous supply to the charging point.

$>$ Even though the utility grid is fully loaded due to local demand and irradiation variation on PV, EV-charging is not delayed.

$>\quad$ The 11 modes based on load and source availability offer EV charging terminals an uninterrupted supply for charging.

$>$ The total power demand is maintained by the available vehicle and ESU.

$>$ A MATLAB model was developed for the charging station to analyze different types of charging stations, including multiport offerings.

$>$ The experimental setup analyzes the practical feasibility of charging stations.

In addition, the different modes proposed in the EMS showcase better performance and maintain DC bus power effectively by the effective utilization of PV power generation; in addition, renewable generated power is fully stored.

\subsection{A DC Microgrid-Based Charging Station and Its IoT-Based Monitoring System}

The practical feasibility of a charging station with three charging ports was examined to check the time it took to charge an EV. In addition, different capacities of electric vehicles were chosen to test practical conditions. A power converter was used for the charging mode and DC grid side, controlled by a digital controller. Different types of and different ratings of the swapping batteries were selected to analyze the performance through an IOT module (SB1 $=12.5 \mathrm{~V}, \mathrm{SB} 2=12 \mathrm{~V}$ and SB $3=12.7 \mathrm{~V})$. The experimental results for different operating conditions of the charging system, such as grid to vehicle (G2V) and vehicle to grid (V2G), are presented. and 29 .

The experimental results of all operations of the system are shown below in Figures 28 


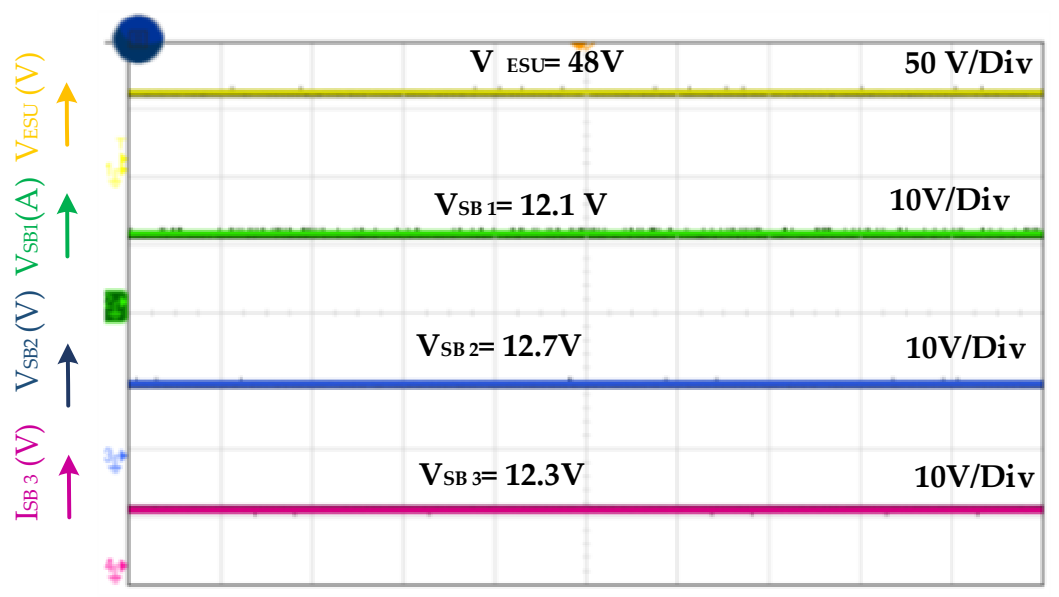

Figure 28. Experimental result of SB and ESU voltage.

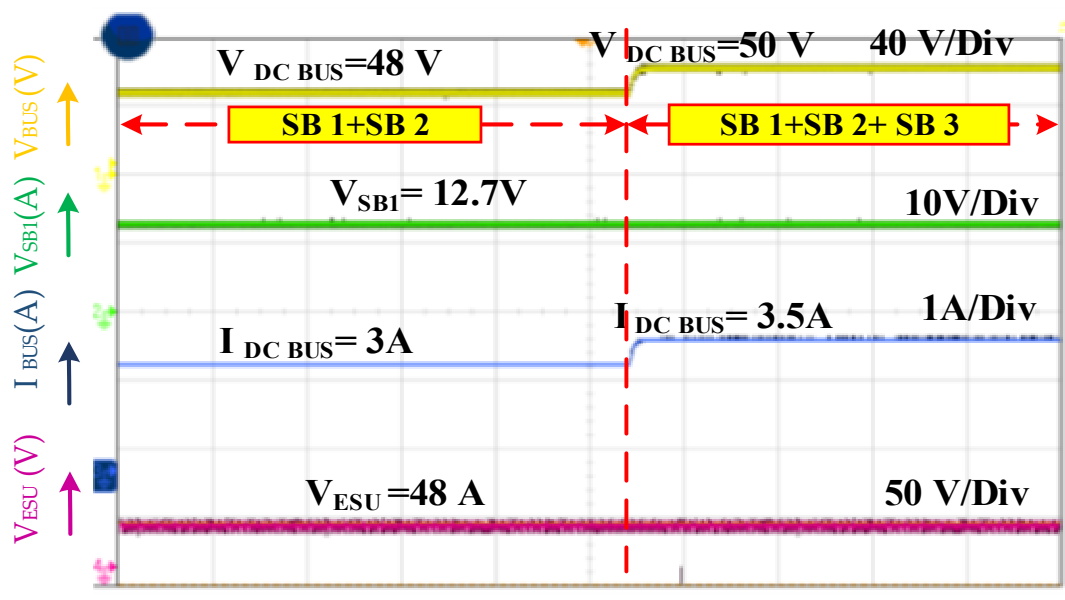

Figure 29. Experimental result of MEV-to-grid charging.

The DC bus voltage is maintained at $48 \mathrm{~V}$ and the SBs are charged with $12 \mathrm{~V}$ with the switching current of the converter at $1.5 \mathrm{~A}$. From the results, it is observed that the EV charging system is functioning satisfactorily in mobile EV-to-EV charging mode. In vehicle-to-vehicle and vehicle-to-mobile electric vehicle ESU charging mode, the DC bus voltage is maintained as $12 \mathrm{~V}$. Swapping battery voltage and ESU voltages are measured, as shown in Figure 28.

In this mode, all the PEVs are fully charged, and the charging station's total power is given to the ESU. Figure 29 shows the MEV-to-grid powering mode, where $48 \mathrm{~V}$ is given to the ESU.

Different modes of PEV charging stations were developed and the function of the system tested for modes like G2V, MEV2G, V2V, and battery swapping is verified. In all the modes, DC bus voltage is maintained. The IoT-based measurement data collected by the DAQ system to the cloud is shown in Figure 30a,b.

This channel provides information on battery voltage, current drawn, SOC, SOH, and battery pack temperature required for safe operation of the battery and swapping details. The battery data is stored and used for monitoring and analyzing. Whenever any abnormality occurs, a notification is sent to the mobile electric vehicle charging station. 


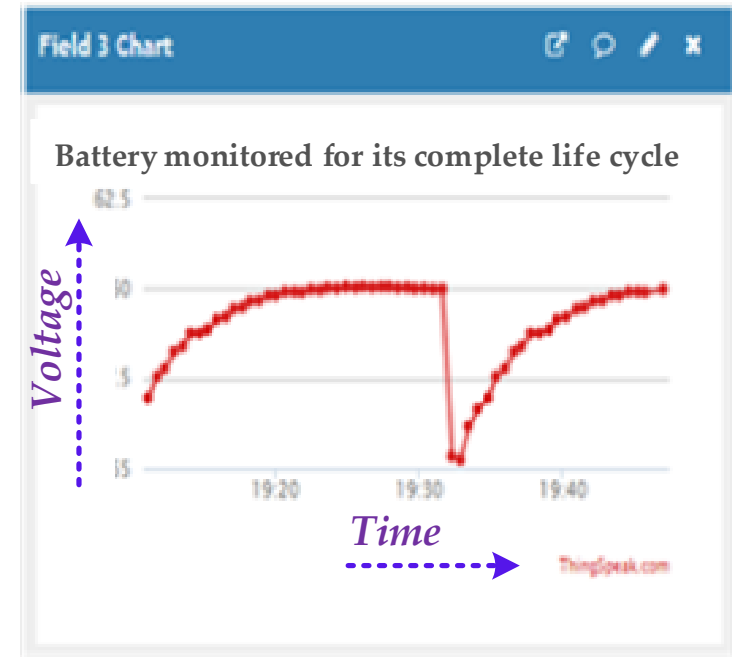

(a)

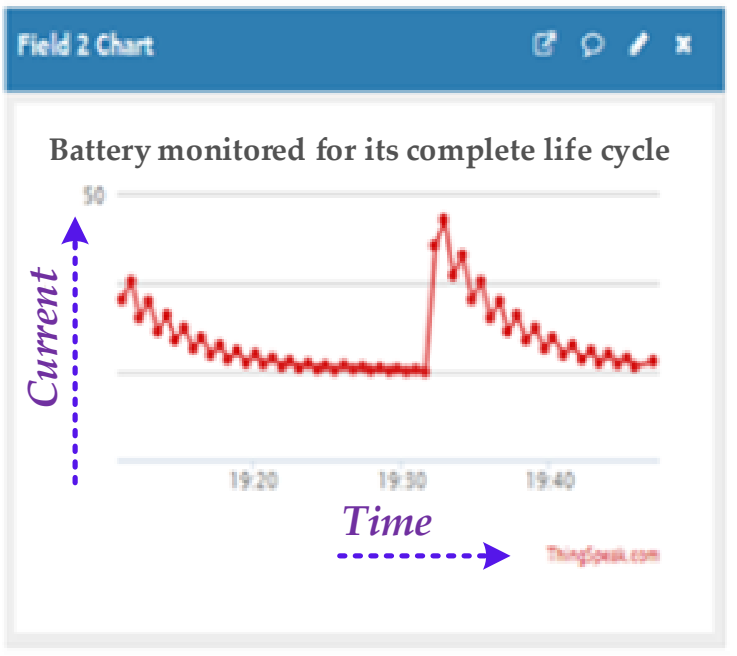

(b)

Figure 30. Discharge response of the battery: (a) Voltage discharge profile, (b) Current discharge profile.

An autonomous system of the battery and BSS parameters for estimation and analysis using IoT is designed:

$>$ The cloud delivers a swapping battery condition report to the driver's mobile device directly after detecting unusual conditions in the battery.

$>\quad$ The battery swapping parameters' detection and storage in the cloud helps develop the business model.

The measured data and testing conditions of the developed prototype show that the proposed scheme is an efficient alternative method to minimize charging time and increase driver comfort.

\subsection{Energy Management Strategy for a DC Microgrid with Maximum Penetration of RES}

A laboratory-scale DC microgrid with PV, fuel cell, and wind generator are taken into consideration. These sources are connected to the DC bus by a suitable converter. The main objective is to maintain DC bus voltage through the battery connected in parallel. The hardware details of the DC microgrid are presented in Table 17.

The EMS is tested under the following cases:

1. $\mathrm{PG}>\mathrm{PL}$ (the priority load is the lighting load that charges during the day and discharges at night)

2. $\mathrm{PG}=\mathrm{PL}$ (the load is raised at 9 am to 10 am to generate power, load power is $440 \mathrm{~W}$, load current is $2 \mathrm{~A}$, and the generated power continuously supplies the load without any interruption)

3. PG $<$ PL (from $8 \mathrm{pm}$ to $12 \mathrm{am}$, the load is considered to be $900 \mathrm{~W}$ and available generation is $600 \mathrm{~W}$ )

The results satisfy the EMS for DC microgrid architecture that is scalable for $15 \mathrm{~kW}$ to satisfy the load demand in rural communities. The experimental results at different time periods are presented in Table 18.

Experimental studies on DC microgrids with the proposed EMS clearly indicate that power is dissipated to consumers throughout the day with maximum renewable energy penetration and batteries without any divergence in the system. Thus, the proposed EMS is verified through a laboratory-scale, real-time DC microgrid experimental setup, confirming its merits. 
Table 17. Description of the hardware components used.

\begin{tabular}{|c|c|c|c|c|c|c|c|c|c|c|c|}
\hline Parameters & $\begin{array}{l}\text { DC Bus } \\
\text { Voltage }\end{array}$ & $\begin{array}{l}\text { Capacity of Wind } \\
\text { Generator }\end{array}$ & $\begin{array}{l}\text { Capacity of } \\
\text { PV Panel }\end{array}$ & $\begin{array}{l}\text { Capacity of Fuel } \\
\text { Cell Power }\end{array}$ & Battery Type & Battery Capacity & $\begin{array}{l}\text { DC-DC } \\
\text { Converter }\end{array}$ & Lamp Loads & Load Bus & $\begin{array}{l}\text { Diesel } \\
\text { Generator }\end{array}$ & $\begin{array}{c}\text { Maximum } \\
\text { Current }\end{array}$ \\
\hline Specification & $24 \mathrm{~V}$ & $200 \mathrm{~W}$ & $200 \mathrm{~W}$ & $100 \mathrm{~W}$ & $\begin{array}{l}\text { Tall tubular } \\
\text { C10 }\end{array}$ & $14 \mathrm{Ah} / 12 \mathrm{~V}$ & $24 \mathrm{~V} / 220 \mathrm{~V}$ & $500 \mathrm{~W}$ & $220 \mathrm{~V}$ & $500 \mathrm{~W}$ & $3 \mathrm{~A}$ \\
\hline
\end{tabular}

Table 18. Experimental results at different time periods.

\begin{tabular}{|c|c|c|c|c|c|c|c|c|c|c|c|c|c|c|c|}
\hline \multirow{3}{*}{ Time } & \multirow{3}{*}{$\begin{array}{l}\text { PV Power } \\
\text { (W) }\end{array}$} & \multirow{3}{*}{$\begin{array}{l}\text { Wind Power } \\
\text { (W) }\end{array}$} & \multirow{3}{*}{$\begin{array}{l}\text { Fuel Cell Power } \\
\text { (W) }\end{array}$} & \multicolumn{8}{|c|}{ Loads $(W)$} & \multicolumn{4}{|c|}{ Batteries } \\
\hline & & & & \multicolumn{2}{|c|}{ Generated Power (W) } & \multicolumn{2}{|c|}{ Priority Load } & \multicolumn{2}{|c|}{ Commercial Load } & \multicolumn{2}{|c|}{ Net Lads } & \multicolumn{2}{|c|}{ Priority Load } & \multicolumn{2}{|c|}{ Commercial Load } \\
\hline & & & & $\begin{array}{c}P \\
\text { (W) }\end{array}$ & $\begin{array}{c}\text { I } \\
\text { (A) }\end{array}$ & $\begin{array}{c}P \\
(W)\end{array}$ & $\begin{array}{c}\text { I } \\
\text { (A) }\end{array}$ & $\begin{array}{c}P \\
\text { (W) }\end{array}$ & $\begin{array}{c}\text { I } \\
\text { (A) }\end{array}$ & $\begin{array}{c}P \\
(W)\end{array}$ & $\begin{array}{c}\text { I } \\
\text { (A) }\end{array}$ & $\begin{array}{c}P \\
(W)\end{array}$ & $\begin{array}{c}\text { I } \\
\text { (A) }\end{array}$ & $\begin{array}{c}P \\
(W)\end{array}$ & $\begin{array}{c}\text { I } \\
\text { (A) }\end{array}$ \\
\hline 8 p.m.-12 a.m. & 0 & 150 & 100 & 250 & 1.13 & 100 & 0.5 & 250 & 1.1 & 350 & 1.6 & 100 & 0.5 & 100 & 0.45 \\
\hline 9 a.m.-10 a.m. & 200 & 140 & 100 & 440 & 2 & 100 & 0.5 & 340 & 1.5 & 440 & 2 & -100 & -0.5 & 0 & 0 \\
\hline 7 a.m.-8 a.m. & 100 & 170 & 100 & 370 & 1.68 & 100 & 0.5 & 150 & 0.7 & 250 & 1.2 & -100 & -0.5 & -120 & -0.7 \\
\hline
\end{tabular}




\section{Challenges and Opportunities for Charging Station Infrastructures}

The commercialization of EV usage and its success lies is the development of a charging station infrastructure with standard equipment. In addition, the charging connector should be easily accessible. Accessibility depends on the power levels of the vehicle being connected. The charging station studied was found to have some challenges and opportunities in the selection of architecture, adaptation of renewable sources, maintaining voltage fluctuation, and development of control schemes.

\subsection{Challenges}

- Optimal location for electric vehicle charging stations: An ideal location is critical in reducing the range of anxiety experienced by electric vehicle buyers. Several factors influence the location of charging stations, including drivers' satisfaction with charging, operators' economic problems, vehicle power loss, power grid safety, and transportation system and traffic congestion.

- The following problems were assumed while conducting the research:

a. Charging demand (mainly by BEV)

b. Charging facility features

c. Charging fees and electricity cost

d. Cost of station installation, operation, maintenance, and land acquisition

- Development of fast charging, ultra-fast charging, and battery swapping stations to reduce EV-charging time.

- Provision of queue management based on the strategy at the charging station.

- To maintain energy balance, a proper grid integration structure with charging stations is required.

- A communication system between the charging point to EV and grid management and the ability to quickly identify a vehicle and make the billing process as simple as possible. Charge cost optimization by selecting the most appropriate time and charging rates. Optimize grid load by adjusting charger capacity in response to grid demand. Use V2G technology to support grid operation during peak loads.

- Energy storage technologies in EV charging stations, particularly fast and ultra-fast charging stations, support stable operation, and improve customer satisfaction. In order to define their contribution level in terms of energy supply for EV-charging, ESS sizing is critical in charging station infrastructure.

- Architecture: Efficiency of the existing utility grid system is decreased due to EV charging loads.

- Adaptation of renewable sources: High cost of installation of renewable energy sources and compliance with multiple charging protocols.

- Accommodation of land space: The promotions of EV charging stations with renewable energy sources occupy large land areas that can increase the cost of installation.

- Energy management: There are many challenges in EMS, such as low efficiency at charging port, reliability and prediction of batteries from overcharging.

- DC link interfacing: Interfacing of renewables creates voltage fluctuation in DC links and requires a regulated output from the sources.

- Selection of converters: Number of switching devices and storage devices in converter topology lead to more losses in conversion. In addition, control of the converter requires a suitable control.

- Control scheme: The control methodology selection for a suitable power rating application requires detailed analysis and dedicated control.

\subsection{Opportunities}

- Optimal selection of charging stations based on the demand for charging (primarily from BEVs), charging facility features, fees and electricity costs, station installation, operation, and maintenance costs, as well as land acquisition costs; there is literature available on optimization. 
- The optimal development of charging infrastructure necessitates careful planning in terms of charging station location and size. A large charging station can accommodate a greater number of chargers to accommodate more EVs; nevertheless, it will also require more electrical energy and construction costs.

- The charging infrastructure requirements are highly dependent on EV battery sizes and power rates, both of which are expected to rise in the future.

- Development of fast-charging, ultra-fast charging, and battery swapping stations are being developed to reduce EV-charging time.

- The rate of EV adoption has a significant impact on the development of fast- and ultra-fast charging stations, as well as the profitability of their operation.

- It is critical to regulate and schedule the available charging stations in order to charge an electric vehicle. This will aid in the strategic management of EV queues at charging stations. The management of queues will be aided by an effective communication network.

- Several communication protocols and standards are available for billing and managing the charging.

- Architecture: The charging station, by connecting renewable sources and bidirectional power converter in the charging station architecture, meets grid demand through V2G technology.

- Adaptation of renewable sources: Charging pricing decreases, emission reduces, and the utility grid does not overload.

- Accommodation of land space: The installations of more charging stations lead to an increase in the number of vehicles on the road.

- Energy management: The energy management system in charging stations with renewable sources makes full use of solar energy; thus, the operating cost is reduced, resulting in maximum benefit.

- DC link interfacing: EV-charging depends on storage devices; effectively connected DC energy storages provide better efficiency.

- Selection of converters: A suitable converter and control strategy leads to increased efficiency and reduces charging time.

- Control scheme: The conventional and intelligent control, the optimization algorithm, is used to provide better control.

\section{Conclusions}

This paper summarized a recent literature study on renewable energy sources-powered EV charging stations' topologies and the importance of different types of charging station architectures. The different categories of architecture are classified based on RES integration with DC, AC, and hybrid microgrids. Charging converter topologies and their bidirectional power flow options for DC bus voltage regulations are also presented. The main difficulty in a charging station is the connection of the DC and AC loads, i.e. charging points of DC levels. Different control strategies in microgrid charging stations were also reviewed, which can provide guidance in selecting an apt control technology. The AC microgrid-based charging station follows droop control characteristics, which gives higher stability at higher gains compared to frequency droop control; however, it requires a communication channel. The DC microgrid-based charging station with simple DC-DC conversion, on the other hand, provides a fast-charging option and reduces conversion loss. Different connectors are also presented, which help in selecting a charging connector based on charging levels.

The following observations have been made in this review:

- In AC microgrids, the controller can manage frequency, voltage regulation, and real and reactive power control.

- The DC microgrid-based charging station is more suitable due to conversion losses.

- The energy storage unit in the charging station provides uninterrupted EV-charging and ESU provides an option for effective usage of renewable energy sources. 
- ESU integration with microgrids through dedicated converters enables fast charging and discharging.

- DC microgrid-based charging station control through DC link voltage and power prediction provides better efficiency.

- Controlling of microgrids through fuzzy logic and optimization technique-based energy management strategy provides better regulation and optimal management of fast charging.

- Charging side converters with bidirectional power flow support grid voltage regulation through constant current and voltage charging.

The adoption of new technologies for EV-charging, such as V2G, smart grid, smart charging technique, etc., will be extremely beneficial in maintaining the power system's energy balance and maximizing the use of available renewable energy. It will also assist in achieving customer satisfaction as well as ensuring cost-effective charging rates. The development of an efficient optimization unit for shorter charging times, as well as a prediction unit to aid in the best possible optimization, are critical for the efficient operation of EV charging infrastructure. To meet the goals of reduced reliance on fossil fuels and zero emissions of environmentally polluting gases, a stable distributed or microgrid system network with maximized energy generation from a renewable energy system must be promoted to feed increasing and dynamic electrical loads in the form of EVs.

Author Contributions: Conceptualization, D.S.A. and B.C.; methodology, D.S.A., B.C., L.M.-P. and N.R.; software, S.R.G.T.R.; validation, D.S.A., K.M.S., B.C. and N.R.; formal analysis, D.S.A., B.C. and N.R.; investigation, D.S.A., B.C. and N.R.; resources, L.M.-P. and N.R.; data curation, D.S.A., K.M.S., B.C. and N.R.; writing—original draft preparation, D.S.A., B.C. and N.R.; writing-review and editing, D.S.A., B.C. and L.M.-P.; visualization, L.K.; supervision, B.C. and L.M.-P.; project administration, R.V.; funding acquisition, L.M.-P. and B.C. All authors have read and agreed to the published version of the manuscript.

Funding: This research is associated with the project of Deanship of Scientific Research at King Khalid University, Kingdom of Saudi Arabia, for funding this work through the General Research Project under grant number RGP. 1/262/42.

Data Availability Statement: Experimental data is available upon request.

Conflicts of Interest: The authors declare no conflict of interest.

\section{References}

1. Woodcock, J.; Edwards, P.; Tonne, C.; Armstrong, B.G.; Ashiru, O.; Banister, D.; Beevers, S.; Chalabi, Z.; Chowdhury, Z.; Cohen, A.; et al. Public health benefits of strategies to reduce greenhouse-gas emissions: Urban land transport. Lancet 2009, 374, 1930-1943. [CrossRef]

2. Pepermans, G.; Driesen, J.; Haeseldonckx, D.; Belmans, R.; D’Haeseleer, W. Distributed generation: Definition, benefits and issues. Energy Policy 2005, 33, 787-798. [CrossRef]

3. Lasseter, R.; Paigi, P. Microgrid: A conceptual solution. In Proceedings of the 2004 IEEE 35th Annual Power Electronics Specialists Conference (IEEE Cat. No.04CH37551), Aachen, Germany, 20-25 June 2004; Volume 6, pp. 4285-4290.

4. Schroeder, A.; Traber, T. The economics of fast charging infrastructure for electric vehicles. Energy Policy 2012, 43, 136-144. [CrossRef]

5. Richardson, P.; Flynn, D.; Keane, A. Local Versus Centralized Charging Strategies for Electric Vehicles in Low Voltage Distribution Systems. IEEE Trans. Smart Grid 2012, 3, 1020-1028. [CrossRef]

6. Liu, L.; Kong, F.; Liu, X.; Peng, Y.; Wang, Q. A review on electric vehicles interacting with renewable energy in smart grid. Renew. Sustain. Energy Rev. 2015, 51, 648-661. [CrossRef]

7. Clement-Nyns, K.; Haesen, E.; Driesen, J. The Impact of Charging Plug-In Hybrid Electric Vehicles on a Residential Distribution Grid. IEEE Trans. Power Syst. 2009, 25, 371-380. [CrossRef]

8. Kempton, W.; Tomić, J. Vehicle-to-grid power implementation: From stabilizing the grid to supporting large-scale renewable energy. J. Power Sources 2005, 144, 280-294. [CrossRef]

9. Dragicevic, T.; Lu, X.; Vasquez, J.C.; Guerrero, J. DC Microgrids-Part II: A Review of Power Architectures, Applications, and Standardization Issues. IEEE Trans. Power Electron. 2016, 31, 3528-3549. [CrossRef]

10. Kuperman, A.; Levy, U.; Goren, J.; Zafransky, A.; Savernin, A. Battery Charger for Electric Vehicle Traction Battery Switch Station. IEEE Trans. Ind. Electron. 2013, 60, 5391-5399. [CrossRef] 
11. Yang, B.; Li, W.; Zhao, Y.; He, X. Design and Analysis of a Grid-Connected Photovoltaic Power System. IEEE Trans. Power Electron. 2010, 25, 992-1000. [CrossRef]

12. Che, L.; Shahidehpour, M.; AlAbdulwahab, A.; Al-Turki, Y. Hierarchical Coordination of a Community Microgrid with AC and DC Microgrids. IEEE Trans. Smart Grid 2015, 6, 3042-3051. [CrossRef]

13. Bajaj, M.; Singh, A. Grid integrated renewable DG systems: A review of power quality challenges and state-of-the-art mitigation techniques. Int. J. Energy Res. 2020, 44, 26-69. [CrossRef]

14. Basak, P.; Chowdhury, S.; Dey, S.H.N. A literature review on integration of distributed energy resources in the perspective of control, protection and stability of microgrid. Renew. Sustain. Energy Rev. 2012, 16, 5545-5556. [CrossRef]

15. Hatziargyriou, N.; Asano, H.; Iravani, R.; Marnay, C. Microgrids. IEEE Power Energy Mag. 2007, 5, 78-94. [CrossRef]

16. Guerrero, J.; Vasquez, J.C.; Matas, J.; de Vicuña, L.G.; Castilla, M. Hierarchical Control of Droop-Controlled AC and DC Microgrids-A General Approach Toward Standardization. IEEE Trans. Ind. Electron. 2011, 58, 158-172. [CrossRef]

17. Oleynik, V.; Albul, G. Multipurpose, Universal Converter with Battery Control and Real-Time Power Factor Correction. U.S. Patent 9,178,354, 3 November 2015.

18. Tan, L.; Zhu, N.; Wu, B. An Integrated Inductor for Eliminating Circulating Current of Parallel Three-Level DC-DC ConverterBased EV Fast Charger. IEEE Trans. Ind. Electron. 2015, 63, 1362-1371. [CrossRef]

19. Lee, C.-T.; Chu, C.-C.; Cheng, P.-T. A New Droop Control Method for the Autonomous Operation of Distributed Energy Resource Interface Converters. IEEE Trans. Power Electron. 2013, 28, 1980-1993. [CrossRef]

20. Li, F.; Qiao, W.; Sun, H.; Wan, H.; Wang, J.; Xia, Y.; Xu, Z.; Zhang, P. Smart Transmission Grid: Vision and Framework. IEEE Trans. Smart Grid 2010, 1, 168-177. [CrossRef]

21. Gurin, M.H. Hybrid Power Generation and Energy Storage System. U.S. Patent 8,099,198, 17 January 2012.

22. Mak, H.-Y.; Rong, Y.; Shen, Z.-J.M. Infrastructure Planning for Electric Vehicles with Battery Swapping. Manag. Sci. 2013, 59, 1557-1575. [CrossRef]

23. Van Haaren, R. Assessment of Electric Cars' Range Requirements and Usage Patterns Based on Driving Behavior Recorded in the National Household Travel Survey of 2009; Earth and Environmental Engineering Department, Columbia University; Fu Foundation School of Engineering and Applied Science: New York, NY, USA, 2009; Volume 51, p. 53.

24. Available online: https://www.istockphoto.com/photos/electric-vehicle-charging-station (accessed on 2 June 2021).

25. Talukdar, B.; Deka, B. An Approach to Reliability, Availability and Maintainability Analysis of a Plug-In Electric Vehicle. World Electr. Veh. J. 2021, 12, 34. [CrossRef]

26. Xu, G.; Du, X.; Li, Z.; Zhang, X.; Zheng, M.; Miao, Y.; Gao, Y.; Liu, Q. Reliability design of battery management system for power battery. Microelectron. Reliab. 2018, 88-90, 1286-1292. [CrossRef]

27. Available online: https://globalnews.ca/news/2171804/uk-to-test-roads-that-charge-electric-cars-as-they-drive/ (accessed on 2 June 2021).

28. Chatterjee, S.; Iyer, A.; Bharatiraja, C.; Vaghasia, I.; Rajesh, V. Design Optimisation for an Efficient Wireless Power Transfer System for Electric Vehicles. Energy Procedia 2017, 117, 1015-1023. [CrossRef]

29. McDonough, M. Integration of Inductively Coupled Power Transfer and Hybrid Energy Storage System: A Multiport Power Electronics Interface for Battery-Powered Electric Vehicles. IEEE Trans. Power Electron. 2015, 30, 6423-6433. [CrossRef]

30. Park, M.; Nguyen, V.T.; Yu, S.-D.; Yim, S.-W.; Park, K.; Min, B.D.; Kim, S.-D.; Cho, J.G. A study of wireless power transfer topologies for $3.3 \mathrm{~kW}$ and $6.6 \mathrm{~kW}$ electric vehicle charging infrastructure. In Proceedings of the 2016 IEEE Transportation Electrification Conference and Expo, Asia-Pacific (ITEC Asia-Pacific), Busan, Korea, 1-4 June 2016; pp. 689-692.

31. Chittoor, P.K.; Chokkalingam, B.; Mihet-Popa, L. A Review on UAV Wireless Charging: Fundamentals, Applications, Charging Techniques and Standards. IEEE Access 2021, 9, 69235-69266. [CrossRef]

32. Krishnamoorthy, R.; Krishnan, K.; Chokkalingam, B.; Padmanaban, S.; Leonowicz, Z.; Holm-Nielsen, J.B.; Mitolo, M. Systematic Approach for State-of-the-Art Architectures and System-on-chip Selection for Heterogeneous IoT Applications. IEEE Access 2021, 9, 25594-25622. [CrossRef]

33. Available online: https://www.motorcyclenews.com/news/electric-motorbike-swappable-batteries/ (accessed on 2 June 2021).

34. Rahman, I.; Vasant, P.M.; Singh, B.S.M.; Abdullah-Al-Wadud, M.; Adnan, N. Review of recent trends in optimization techniques for plug-in hybrid, and electric vehicle charging infrastructures. Renew. Sustain. Energy Rev. 2016, 58, 1039-1047. [CrossRef]

35. Kisacikoglu, M.C.; Kesler, M.; Tolbert, L. Single-Phase On-Board Bidirectional PEV Charger for V2G Reactive Power Operation. IEEE Trans. Smart Grid 2015, 6, 767-775. [CrossRef]

36. Furiya, K.; Omura, N.; Nagano, H.; Nishimura, K.; Ueda, A.; Tokura, S. Parallel-connected bilayer coil for a 3.3-kW electric vehicle wireless charging system. In Proceedings of the 2017 IEEE Wireless Power Transfer Conference (WPTC), Taipei, Taiwan, 10-12 May 2017.

37. Mwasilu, F.; Justo, J.J.; Kim, E.-K.; Do, T.; Jung, J.-W. Electric vehicles and smart grid interaction: A review on vehicle to grid and renewable energy sources integration. Renew. Sustain. Energy Rev. 2014, 34, 501-516. [CrossRef]

38. García-Vera, Y.E.; Dufo-López, R.; Bernal-Agustín, J.L. Optimization of Isolated Hybrid Microgrids with Renewable Energy Based on Different Battery Models and Technologies. Energies 2020, 13, 581. [CrossRef]

39. Thiyagarajan, S.; Sonthalia, A.; Geo, V.E.; Chokkalingam, B. Effect of waste exhaust heat on hydrogen production and its utilization in CI engine. Int. J. Hydrogen Energy 2020, 45, 5987-5996. [CrossRef] 
40. Al Badwawi, R.; Abusara, M.; Mallick, T. A Review of Hybrid Solar PV and Wind Energy System. Smart Sci. $2015,3,127-138$. [CrossRef]

41. Suresh, K.; Bharatiraja, C.; Chellammal, N.; Tariq, M.; Chakrabortty, R.K.; Ryan, M.J.; Alamri, B. A Multifunctional Non-Isolated Dual Input-Dual Output Converter for Electric Vehicle Applications. IEEE Access 2021, 9, 64445-64460. [CrossRef]

42. Bhutto, D.K.; Ansari, J.A.; Bukhari, S.S.H.; Chachar, F.A. WIND ENERGY CONVERSION SYSTEMS (WECS) GENERATORS: A REVIEW. In Proceedings of the 2019 2nd International Conference on Computing, Mathematics and Engineering Technologies (iCoMET), Sukkur, Pakistan, 30-31 January 2019; pp. 1-6.

43. IEC. IEC. 61643-11: Low-Voltage Surge Protective Devices-Part 11: Surge Protective Devices Connected to Low-Voltage Power Distribution Systems-Requirements and Test Methods; BSI: London, UK, 2011.

44. Kersten, A.; Rodionov, A.; Kuder, M.; Hammarström, T.; Lesnicar, A.; Thiringer, T. Review of Technical Design and Safety Requirements for Vehicle Chargers and Their Infrastructure According to National Swedish and Harmonized European Standards. Energies 2021, 14, 3301. [CrossRef]

45. Samson, N. Smart Plug-Optimization of design and material regarding environmental aspects: Mechanical design of an environmentally friendly Smart Plug. Master's Thsesis, Karlstad University, Karlstad, Suedia, 2020.

46. Musavi, F.; Edington, M.; Eberle, W.; Dunford, W.G. Evaluation and Efficiency Comparison of Front End AC-DC Plug-in Hybrid Charger Topologies. IEEE Trans. Smart Grid 2012, 3, 413-421. [CrossRef]

47. Anand, S.; Fernandes, B.G. Optimal voltage level for DC microgrids. In Proceedings of the IECON 2010-36th Annual Conference on IEEE Industrial Electronics Society; IEEE: Piscataway, NJ, USA, 2010; pp. 3034-3039.

48. Sharma, A.; Srinivasan, D.; Trivedi, A. A Decentralized Multiagent System Approach for Service Restoration Using DG Islanding. IEEE Trans. Smart Grid 2015, 6, 2784-2793. [CrossRef]

49. Gamboa, G.; Hamilton, C.; Kerley, R.; Elmes, S.; Arias, A.; Shen, J.; Batarseh, I. Control strategy of a multi-port, grid connected, direct-DC PV charging station for plug-in electric vehicles. In 2010 IEEE Energy Conversion Congress and Exposition; IEEE: Piscataway, NJ, USA, 2010; pp. 1173-1177.

50. Ma, T.T.H.; Yahoui, H.; Vu, H.G.; Siauve, N.; Morel, H. A Control Strategy of DC Building Microgrid Connected to the Neighborhood and AC Power Network. Buildings 2017, 7, 42. [CrossRef]

51. Barker, P.P.; De Mello, R. Determining the impact of distributed generation on power systems. I. Radial distribution systems. In Proceedings of the 2000 Power Engineering Society Summer Meeting (Cat. No.00CH37134); Institute of Electrical and Electronics Engineers (IEEE): Piscataway, NJ, USA, 2002; pp. 1645-1656.

52. Clairand, J.-M.; Álvarez-Bel, C.; Rodríguez-García, J.; Escrivá-Escrivá, G. Impact of Electric Vehicle Charging Strategy on the Long-Term Planning of an Isolated Microgrid. Energies 2020, 13, 3455. [CrossRef]

53. Guerrero, J.; Chandorkar, M.; Lee, T.-L.; Loh, P.C. Advanced Control Architectures for Intelligent Microgrids—Part I: Decentralized and Hierarchical Control. IEEE Trans. Ind. Electron. 2013, 60, 1254-1262. [CrossRef]

54. Majumder, R.; Ghosh, A.; Ledwich, G.; Zare, F. Power Management and Power Flow Control with Back-to-Back Converters in a Utility Connected Microgrid. IEEE Trans. Power Syst. 2010, 25, 821-834. [CrossRef]

55. Queiroz, J.; Dias, A.; Leitao, P. Predictive data analytics for agent-based management of electrical micro grids. In Proceedings of the IECON 2015-41st Annual Conference of the IEEE Industrial Electronics Society, Yokohama, Japan, 9-12 November 2015; pp. $4684-4689$.

56. Wang, B.; Sechilariu, M.; Locment, F. Intelligent DC Microgrid with Smart Grid Communications: Control Strategy Consideration and Design. IEEE Trans. Smart Grid 2012, 3, 2148-2156. [CrossRef]

57. Kanchev, H.; Colas, F.; Lazarov, V.; Francois, B. Emission reduction and economical optimization of an urban microgrid operation including dispatched PV-based active generators. IEEE Trans. Sustain. Energy 2014, 5, 1397-1405. [CrossRef]

58. Ms, K.; Nattuthurai, S.; Chokkalingam, B.; Muthusamy, S.; Cherukupalli, K. Development of ripple reduced solar photovoltaic regulators using boomerang sliding mode control strategy. Int. J. Circuit Theory Appl. 2021. [CrossRef]

59. Panchu, S.J.; Raju, K.; Swart, H.C.; Chokkalingam, B.; Maaza, M.; Henini, M.; Moodley, M.K. Luminescent MoS2 Quantum Dots with Tunable Operating Potential for Energy-Enhanced Aqueous Supercapacitors. ACS Omega 2021, 6, 4542-4550. [CrossRef] [PubMed]

60. You, P.; Yang, Z.; Chow, M.-Y.; Sun, Y. Optimal Cooperative Charging Strategy for a Smart Charging Station of Electric Vehicles. IEEE Trans. Power Syst. 2016, 31, 2946-2956. [CrossRef]

61. Atawi, I.; Hendawi, E.; Zaid, S. Analysis and Design of a Standalone Electric Vehicle Charging Station Supplied by Photovoltaic Energy. Processes 2021, 9, 1246. [CrossRef]

62. Sánchez-Sáinz, H.; Vázquez, C.A.G.; Iborra, F.L.; Fernández-Ramírez, L.M. Methodology for the Optimal Design of a Hybrid Charging Station of Electric and Fuel Cell Vehicles Supplied by Renewable Energies and an Energy Storage System. Sustainability 2019, 11, 5743. [CrossRef]

63. Dos Santos, L.T.; Sechilariu, M.; Locment, F. Day-ahead microgrid optimal self-scheduling: Comparison between three methods applied to isolated DC microgrid. In Proceedings of the IECON 2014-40th Annual Conference of the IEEE Industrial Electronics Society, Dallas, TX, USA, 29 October-1 November 2014; pp. 2010-2016.

64. Kharrich, M.; Kamel, S.; Ellaia, R.; Akherraz, M.; Alghamdi, A.; Abdel-Akher, M.; Eid, A.; Mosaad, M. Economic and Ecological Design of Hybrid Renewable Energy Systems Based on a Developed IWO/BSA Algorithm. Electronics 2021, 10, 687. [CrossRef] 
65. Bhargavi, K.M.; Jayalakshmi, N.S. A New Control Strategy for Plug-in Electric Vehicle of DC Microgrid with PV and Wind Power Integration. J. Electr. Eng. Technol. 2019, 14, 13-25. [CrossRef]

66. Rahman, S.; Hossain, M.J.; Rafi, F.H.M.; Lu, J. EV charging in a commercial hybrid AC/DC microgrid: Configuration, control and impact analysis. In Proceedings of the 2016 Australasian Universities Power Engineering Conference (AUPEC); IEEE: Piscataway, NJ, USA, 2016; pp. 1-6.

67. Kamalesh, M.; Senthilnathan, N.; Bharatiraja, C. Design of a Novel Boomerang Trajectory for Sliding Mode Controller. Int. J. Control. Autom. Syst. 2020, 18, 2917-2928. [CrossRef]

68. Karthikeyan, M.; Elavarasu, R.; Ramesh, P.; Bharatiraja, C.; Sanjeevikumar, P.; Mihet-Popa, L.; Mitolo, M. A Hybridization of Cuk and Boost Converter Using Single Switch with Higher Voltage Gain Compatibility. Energies 2020, 13, 2312. [CrossRef]

69. Savio, D.A.; Juliet, V.A.; Chokkalingam, B.; Padmanaban, S.; Holm-Nielsen, J.B.; Blaabjerg, F. Photovoltaic Integrated Hybrid Microgrid Structured Electric Vehicle Charging Station and Its Energy Management Approach. Energies 2019, 12, 168. [CrossRef]

70. Ramesh, K.; Bharatiraja, C.; Raghu, S.; Vijayalakshmi, G.; Sambanthan, P. Design and Implementation of Real Time Charging Optimization for Hybrid Electric Vehicles. Int. J. Power Electron. Drive Syst. 2016, 7, 1261-1268. [CrossRef]

71. Derakhshandeh, S.Y.; Masoum, A.S.; Deilami, S.; Masoum, M.A.S.; Golshan, M.E.H. Coordination of Generation Scheduling with PEVs Charging in Industrial Microgrids. IEEE Trans. Power Syst. 2013, 28, 3451-3461. [CrossRef]

72. Liu, Y.; Tang, Y.; Shi, J.; Shi, X.; Deng, J.; Gong, K. Application of Small-Sized SMES in an EV Charging Station With DC Bus and PV System. IEEE Trans. Appl. Supercond. 2014, 25, 1-6. [CrossRef]

73. Gundabathini, R.; Pindoriya, N.M. Improved Control Strategy for Bidirectional Single Phase AC-DC Converter in Hybrid AC/DC Microgrid. Electr. Power Compon. Syst. 2017, 45, 2293-2303. [CrossRef]

74. Bhatti, A.R.; Salam, Z.; Aziz, M.J.A.; Yee, K.P. A critical review of electric vehicle charging using solar photovoltaic. Int. J. Energy Res. 2016, 40, 439-461. [CrossRef]

75. Fretzen, U.; Ansarin, M.; Brandt, T. Temporal city-scale matching of solar photovoltaic generation and electric vehicle charging. Appl. Energy 2021, 282, 116160. [CrossRef]

76. Kamaraj, V.; Chellammal, N.; Chokkalingam, B.; Munda, J.L. Minimization of Cross-Regulation in PV and Battery Connected Multi-Input Multi-Output DC to DC Converter. Energies 2020, 13, 6534. [CrossRef]

77. Periyanayagam, M.; Velu, S.K.; Chokkalingam, B.; Padmanaban, S.; Mihet-Popa, L.; Adedayo, Y. A Modified High Voltage Gain Quasi-Impedance Source Coupled Inductor Multilevel Inverter for Photovoltaic Application. Energies 2020, 13, 874. [CrossRef]

78. Gunasekaran, M.; Mohamed Ismail, H.; Chokkalingam, B.; Mihet-Popa, L.; Padmanaban, S. Energy Management Strategy for Rural Communities' DC Micro Grid Power System Structure with Maximum Penetration of Renewable Energy Sources. Appl. Sci. 2018, 8, 585. [CrossRef]

79. Goli, P.; Shireen, W. PV powered smart charging station for PHEVs. Renew. Energy 2014, 66, 280-287. [CrossRef]

80. Zhao, J.; Kucuksari, S.; Mazhari, E.; Son, Y.-J. Integrated analysis of high-penetration PV and PHEV with energy storage and demand response. Appl. Energy 2013, 112, 35-51. [CrossRef]

81. Sun, K.; Zhang, L.; Xing, Y.; Guerrero, J. A Distributed Control Strategy Based on DC Bus Signaling for Modular Photovoltaic Generation Systems with Battery Energy Storage. IEEE Trans. Power Electron. 2011, 26, 3032-3045. [CrossRef]

82. Ms, K.; Nattuthurai, S.; Chokkalingam, B.; Mihet-Popa, L. Mitigation of circulating current with effective energy management in low-power PV-FC-battery-microgrid. Int. Trans. Electr. Energy Syst. 2021, 31, e12899. [CrossRef]

83. Gurkaynak, Y.; Khaligh, A. Control and Power Management of a Grid Connected Residential Photovoltaic System with Plug-in Hybrid Electric Vehicle (PHEV) Load. In Proceedings of the 2009 Twenty-Fourth Annual IEEE Applied Power Electronics Conference and Exposition, Washington, DC, USA, 15-19 February 2009; pp. 2086-2091.

84. Ma, T.; Mohammed, O. Optimal Charging of Plug-in Electric Vehicles for a Car-Park Infrastructure. IEEE Trans. Ind. Appl. 2014, 50, 2323-2330. [CrossRef]

85. Knight, A.; Peters, G. Simple Wind Energy Controller for an Expanded Operating Range. IEEE Trans. Energy Convers. 2005, 20, 459-466. [CrossRef]

86. Jeong, Y.-M.; Cho, Y.-K.; Ahn, J.-H.; Ryu, S.-H.; Lee, B.-K. Enhanced Coulomb counting method with adaptive SOC reset time for estimating OCV. In 2014 IEEE Energy Conversion Congress and Exposition (ECCE); IEEE: Piscataway, NJ, USA, 2014; pp. 1313-1318.

87. Semenov, D.; Mirzaeva, G.; Townsend, C.; Goodwin, G. An AC microgrid architecture and control strategy to achieve stability with any type of load. In Proceedings of the 2017 IEEE Southern Power Electronics Conference (SPEC); IEEE: Piscataway, NJ, USA, 2017; pp. 1-6.

88. Diaz, N.L.; Luna, A.C.; Vasquez, J.C.; Guerrero, J. Centralized Control Architecture for Coordination of Distributed Renewable Generation and Energy Storage in Islanded AC Microgrids. IEEE Trans. Power Electron. 2017, 32, 5202-5213. [CrossRef]

89. Falvo, M.C.; Sbordone, D.; Bayram, I.S.; Devetsikiotis, M. EV charging stations and modes: International standards. In Proceedings of the 2014 International Symposium on Power Electronics, Electrical Drives, Automation and Motion; IEEE: Piscataway, NJ, USA, 2014; pp. 1134-1139.

90. Yang, J.; He, L.; Fu, S. An improved PSO-based charging strategy of electric vehicles in electrical distribution grid. Appl. Energy 2014, 128, 82-92. [CrossRef]

91. Jha, M.; Blaabjerg, F.; Khan, M.A.; Kurukuru, V.S.B.; Haque, A. Intelligent Control of Converter for Electric Vehicles Charging Station. Energies 2019, 12, 2334. [CrossRef] 
92. Luo, C.; Huang, Y.-F.; Gupta, V. Stochastic Dynamic Pricing for EV Charging Stations with Renewable Integration and Energy Storage. IEEE Trans. Smart Grid 2017, 9, 1494-1505. [CrossRef]

93. Sun, B.; Dragicevic, T.; Freijedo, F.D.; Vasquez, J.C.; Guerrero, J. A Control Algorithm for Electric Vehicle Fast Charging Stations Equipped With Flywheel Energy Storage Systems. IEEE Trans. Power Electron. 2015, 31, 6674-6685. [CrossRef]

94. Rafique, M.K.; Khan, S.U.; Zaman, M.S.U.; Mehmood, K.K.; Haider, Z.M.; Bukhari, S.B.A.; Kim, C.-H. An Intelligent Hybrid Energy Management System for a Smart House Considering Bidirectional Power Flow and Various EV Charging Techniques. Appl. Sci. 2019, 9, 1658. [CrossRef]

95. Unamuno, E.; Barrena, J.A. Hybrid ac/dc microgrids-Part I: Review and classification of topologies. Renew. Sustain. Energy Rev. 2015, 52, 1251-1259. [CrossRef]

96. Mane, S.; Kadam, P.; Lahoti, G.; Kazi, F.; Singh, N.M. Optimal load balancing strategy for hybrid energy management system in DC microgrid with PV, fuel cell and battery storage. In Proceedings of the 2016 IEEE International Conference on Renewable Energy Research and Applications (ICRERA); IEEE: Piscataway, NJ, USA, 2016; pp. 851-856.

97. Nayar, C.; Tang, M.; Suponthana, W. Wind/PV/diesel micro grid system implemented in remote islands in the Republic of Maldives. In Proceedings of the 2008 IEEE International Conference on Sustainable Energy Technologies; IEEE: Piscataway, NJ, USA, 2008; pp. 1076-1080.

98. Eghtedarpour, N.; Farjah, E. Power Control and Management in a Hybrid AC/DC Microgrid. IEEE Trans. Smart Grid 2014, 5, 1494-1505. [CrossRef]

99. D'Arco, S.; Suul, J.A. Equivalence of Virtual Synchronous Machines and Frequency-Droops for Converter-Based MicroGrids. IEEE Trans. Smart Grid 2014, 5, 394-395. [CrossRef]

100. Majumder, R.; Chaudhuri, B.; Ghosh, A.; Majumder, R.; Ledwich, G.; Zare, F. Improvement of Stability and Load Sharing in an Autonomous Microgrid Using Supplementary Droop Control Loop. IEEE Trans. Power Syst. 2009, 25, 796-808. [CrossRef]

101. Mohammadi, F.; Nazri, G.-A.; Saif, M. An Improved Droop-Based Control Strategy for MT-HVDC Systems. Electronics 2020, $9,87$. [CrossRef]

102. Chettibi, N.; Mellit, A.; Sulligoi, G.; Pavan, A.M. Adaptive Neural Network-Based Control of a Hybrid AC/DC Microgrid. IEEE Trans. Smart Grid 2016, 9, 1-13. [CrossRef]

103. Cai, N.; Mitra, J. A multi-level control architecture for master-slave organized microgrids with power electronic interfaces. Electr. Power Syst. Res. 2014, 109, 8-19. [CrossRef]

104. Anuradha, M.; Jayasankar, T.; Prakash, N.; Sikkandar, M.Y.; Hemalakshmi, G.; Bharatiraja, C.; Britto, A.S.F. IoT enabled cancer prediction system to enhance the authentication and security using cloud computing. Microprocess. Microsyst. 2021, 80, 103301. [CrossRef]

105. Balasubramanian, S.; Chokkalingam, B.; Krishnamoorthy, R.; Adedayo, Y. Power optimiza-tion through Fuzzy Min Product algorithm for voltage assignment in SOC design. J. Appl. Sci. Eng. 2020, 23, 655-659.

106. Liu, X.; Wang, P.; Loh, P.C. A Hybrid AC/DC Microgrid and Its Coordination Control. IEEE Trans. Smart Grid 2011, 2, 278-286. [CrossRef]

107. Zhang, D.Q.; Feng, Y.; Luo, Y.; Huang, Y.X.; Xia, C.L. Energy Management for a Residential Microgrid Using Wavelet Transform and Fuzzy Control Including a Vehicle-to-Grid System. J. Electron. Sci. Technol. 2016, 14, 291-297.

108. Nejabatkhah, F.; Li, Y.W.; Tian, H. Power Quality Control of Smart Hybrid AC/DC Microgrids: An Overview. IEEE Access 2019, 7, 52295-52318. [CrossRef]

109. Aljohani, T.M.; Ebrahim, A.F.; Mohammed, O. Hybrid Microgrid Energy Management and Control Based on Metaheuristic-Driven Vector-Decoupled Algorithm Considering Intermittent Renewable Sources and Electric Vehicles Charging Lot. Energies 2020, 13, 3423. [CrossRef]

110. Zeng, J.; Qiao, W.; Qu, L. An Isolated Three-Port Bidirectional DC-DC Converter for Photovoltaic Systems with Energy Storage. IEEE Trans. Ind. Appl. 2015, 51, 3493-3503. [CrossRef]

111. Wang, P.; Lu, X.; Wang, W.; Xu, D. Frequency Division Based Coordinated Control of Three-Port Converter Interfaced Hybrid Energy Storage Systems in Autonomous DC Microgrids. IEEE Access 2018, 6, 25389-25398. [CrossRef]

112. Jin, C.; Nanyang Technological University; Wang, J.; Wang, P. Coordinated secondary control for autonomous hybrid three-port AC/DC/DS microgrid. CSEE J. Power Energy Syst. 2018, 4, 1-10. [CrossRef]

113. Amir, A.; Che, H.S.; Amir, A.; El Khateb, A.; Abd Rahim, N. Transformerless high gain boost and buck-boost DC-DC converters based on extendable switched capacitor (SC) cell for stand-alone photovoltaic system. Sol. Energy 2018, 171, 212-222. [CrossRef]

114. Mouli, G.C.; Bauer, P.; Zeman, M. System design for a solar powered electric vehicle charging station for workplaces. Appl. Energy 2016, 168, 434-443. [CrossRef]

115. Zhang, Y.; He, J.; Ionel, D.M. Modeling and Control of a Multiport Converter based EV Charging Station with PV and Battery. In Proceedings of the 2019 IEEE Transportation Electrification Conference and Expo (ITEC); IEEE: Piscataway, NJ, USA, 2019; pp. 1-5.

116. Gu, C.; Zheng, Z.; Xu, L.; Wang, K.; Li, Y. Modeling and Control of a Multiport Power Electronic Transformer (PET) for Electric Traction Applications. IEEE Trans. Power Electron. 2016, 31, 915-927. [CrossRef]

117. Sethuraman, S.S.S.; Santha, K.R.; Mihet-Popa, L.; Bharatiraja, C. A Modified Topology of a High Efficiency Bidirectional Type DC-DC Converter by Synchronous Rectification. Electronics 2020, 9, 1555. [CrossRef]

118. Suresh, K.; Chellammal, N.; Bharatiraja, C.; Sanjeevikumar, P.; Blaabjerg, F.; Nielsen, J.B.H. Cost-efficient nonisolated three-port DC-DC converter for EV/HEV applications with energy storage. Int. Trans. Electr. Energy Syst. 2019, 29, 12088. [CrossRef] 
119. Jiang, W.; Fahimi, B. Multiport Power Electronic Interface-Concept, Modeling, and Design. IEEE Trans. Power Electron. 2010, 26, 1890-1900. [CrossRef]

120. Sechilariu, M.; Locment, F.; Wang, B. Photovoltaic Electricity for Sustainable Building. Efficiency and Energy Cost Reduction for Isolated DC Microgrid. Energies 2015, 8, 7945-7967. [CrossRef]

121. Sun, Q.; Wu, J.; Gan, C.; Si, J.; Guo, J.; Hu, Y. Cascaded Multiport Converter for SRM-Based Hybrid Electrical Vehicle Applications. IEEE Trans. Power Electron. 2019, 34, 11940-11951. [CrossRef]

122. Carli, G.; Williamson, S.S. Technical Considerations on Power Conversion for Electric and Plug-in Hybrid Electric Vehicle Battery Charging in Photovoltaic Installations. IEEE Trans. Power Electron. 2013, 28, 5784-5792. [CrossRef]

123. Chandrasekar, B.; Nallaperumal, C.; Padmanaban, S.; Bhaskar, M.S.; Holm-Nielsen, J.B.; Leonowicz, Z.; Masebinu, S. Non-Isolated High-Gain Triple Port DC-DC Buck-Boost Converter with Positive Output Voltage for Photovoltaic Applications. IEEE Access 2020, 8, 113649-113666. [CrossRef]

124. Nagarajan, A.; Shireen, W. Grid connected residential photovoltaic energy systems with Plug-In Hybrid electric Vehicles (PHEV) as energy storage. In Proceedings of the 2008 IEEE Power and Energy Society General Meeting-Conversion and Delivery of Electrical Energy in the 21st Century; IEEE: Piscataway, NJ, USA, 2010; pp. 1-5.

125. Suarez, C.; Martinez, W. Fast and Ultra-Fast Charging for Battery Electric Vehicles-A Review. In 2019 IEEE Energy Conversion Congress and Exposition (ECCE); IEEE: Piscataway, NJ, USA, 2019; pp. 569-575.

126. Ustun, T.S.; Ozansoy, C.R.; Zayegh, A. Implementing Vehicle-to-Grid (V2G) Technology with IEC 61850-7-420. IEEE Trans. Smart Grid 2013, 4, 1180-1187. [CrossRef]

127. Yilmaz, M.; Krein, P.T. Review of Battery Charger Topologies, Charging Power Levels, and Infrastructure for Plug-In Electric and Hybrid Vehicles. IEEE Trans. Power Electron. 2013, 28, 2151-2169. [CrossRef]

128. Shaukat, N.; Khan, B.; Ali, S.; Mehmood, C.; Khan, J.; Farid, U.; Majid, M.; Anwar, S.; Jawad, M.; Ullah, Z. A survey on electric vehicle transportation within smart grid system. Renew. Sustain. Energy Rev. 2018, 81, 1329-1349. [CrossRef]

129. Guerrero, J.; Loh, P.C.; Lee, T.-L.; Chandorkar, M. Advanced Control Architectures for Intelligent Microgrids-Part II: Power Quality, Energy Storage, and AC/DC Microgrids. IEEE Trans. Ind. Electron. 2013, 60, 1263-1270. [CrossRef]

130. Available online: https:/ / evcharging.enelx.com/resources/blog/552-ev-charging-connector-types (accessed on 2 June 2021).

131. Jia, Q.-S.; Long, T. A review on charging behavior of electric vehicles: Data, model, and control. Control. Theory Technol. 2020, 18, 217-230. [CrossRef]

132. Mi, C.; Bai, H.; Wang, C.; Gargies, S. Operation, design and control of dual H-bridge-based isolated bidirectional DC-DC converter. IET Power Electron. 2008, 1, 507-517. [CrossRef]

133. Chen, Y.-T.; Shiu, S.-M.; Liang, R.-H. Analysis and Design of a Zero-Voltage-Switching and Zero-Current-Switching Interleaved Boost Converter. IEEE Trans. Power Electron. 2011, 27, 161-173. [CrossRef]

134. Bratcu, A.I.; Munteanu, I.; Bacha, S.; Picault, D.; Raison, B. Cascaded DC-DC Converter Photovoltaic Systems: Power Optimization Issues. IEEE Trans. Ind. Electron. 2011, 58, 403-411. [CrossRef]

135. Madasamy, P.; Verma, R.; Rameshbabu, A.; Murugesan, A.; Umamageswari, R.; Munda, J.; Bharatiraja, C.; Mihet-Popa, L. Neutral Point Clamped Transformer-Less Multilevel Converter for Grid-Connected Photovoltaic System. Electronics 2021, $10,977$. [CrossRef]

136. Krishna, T.K.; Susitra, D.; Kumar, S.D. DC Smart Grid System for EV Charging Station. In Advances in Intelligent Systems and Computing; Springer Science and Business Media LLC: Berlin, Germany, 2020; pp. 307-328.

137. Sabzehgar, R.; Roshan, Y.M.; Fajri, P. Modeling and Control of a Multifunctional Three-Phase Converter for Bidirectional Power Flow in Plug-In Electric Vehicles. Energies 2020, 13, 2591. [CrossRef]

138. Available online: https://www.reviewtalks.com/indias-first-electric-vehicle-charging-station-starts-in-nagpur/ (accessed on 2 June 2021).

139. Available online: https://www.news18.com/news/auto/tata-power-aims-to-set-up-700-ev-charging-stations-by-2021-25042 15.html (accessed on 2 June 2021).

140. Available online: https://twitter.com/cmrlofficial/status/1178592717560934400 (accessed on 2 June 2021).

141. Ali, M.; Tariq, M.; Lodi, K.A.; Chakrabortty, R.K.; Ryan, M.J.; Alamri, B.; Bharatiraja, C. Robust ANN-Based Control of Modified PUC-5 Inverter for Solar PV Applications. IEEE Trans. Ind. Appl. 2021, 57, 3863-3876. [CrossRef]

142. Jayakumar, V.; Chokkalingam, B.; Munda, J. A Comprehensive Review on Space Vector Modulation Techniques for Neutral Point Clamped Multi-Level Inverters. IEEE Access 2021, 1. [CrossRef]

143. Shtessel, Y.; Baev, S.; Biglari, H. Unity Power Factor Control in Three-Phase AC/DC Boost Converter Using Sliding Modes. IEEE Trans. Ind. Electron. 2008, 55, 3874-3882. [CrossRef]

144. Salmon, J. Circuit topologies for PWM boost rectifiers operated from 1-phase and 3-phase AC supplies and using either single or split DC rail voltage outputs. In Proceedings of the Proceedings of 1995 IEEE Applied Power Electronics Conference and ExpositionAPEC'95; IEEE: Piscataway, NJ, USA, 2002; Volume 1, pp. 473-479.

145. Jou, H.-L.; Wu, K.-D.; Wu, J.-C.; Lin, Y.-Z.; Su, L.-W. Asymmetric isolated unidirectional multi-level DC-DC power converter. Eng. Sci. Technol. Int. J. 2019, 22, 894-898. [CrossRef]

146. Mao, M.; Zhang, L.; Yang, L.; Chong, B.; Huang, H.; Zhou, L. MPPT using modified salp swarm algorithm for multiple bidirectional PV-Ćuk converter system under partial shading and module mismatching. Sol. Energy 2020, 209, 334-349. [CrossRef] 
147. Revathi, B.S.; Mahalingam, P.; Gonzalez-Longatt, F. Interleaved high gain DC-DC converter for integrating solar PV source to DC bus. Sol. Energy 2019, 188, 924-934. [CrossRef]

148. Elkhateb, A.; Rahim, N.A.; Selvaraj, J.; Uddin, M.N. Fuzzy-Logic-Controller-Based SEPIC Converter for Maximum Power Point Tracking. IEEE Trans. Ind. Appl. 2014, 50, 2349-2358. [CrossRef]

149. Cuoghi, S.; Mandrioli, R.; Ntogramatzidis, L.; Gabriele, G. Multileg Interleaved Buck Converter for EV Charging: Discrete-Time Model and Direct Control Design. Energies 2020, 13, 466. [CrossRef]

150. Repecho, V.; Biel, D.; Ramos-Lara, R.; Vega, P.G. Fixed-Switching Frequency Interleaved Sliding Mode Eight-Phase Synchronous Buck Converter. IEEE Trans. Power Electron. 2017, 33, 676-688. [CrossRef]

151. Kim, D.-H.; Kim, M.-S.; Nengroo, S.H.; Kim, C.-H.; Kim, H.-J. LLC Resonant Converter for LEV (Light Electric Vehicle) Fast Chargers. Electronics 2019, 8, 362. [CrossRef]

152. ElMenshawy, M.; Massoud, A. Development of Modular DC-DC Converters for Low-Speed Electric Vehicles Fast Chargers. Alex. Eng. J. 2021, 60, 1067-1083. [CrossRef]

153. Szymanski, J.R.; Zurek-Mortka, M.; Acharjee, D. Unidirectional voltage converter for battery electric vehicle ultrafast charger. Microsyst. Technol. 2021, 27, 2865-2872. [CrossRef]

154. Rmila, S.A.; Ang, S.S. A High-Input Voltage Two-Phase Series-Capacitor DC-DC Buck Converter. J. Electr. Comput. Eng. 2020, 2020, 1-15. [CrossRef]

155. Bhatti, A.R.; Salam, Z. A rule-based energy management scheme for uninterrupted electric vehicles charging at constant price using photovoltaic-grid system. Renew. Energy 2018, 125, 384-400. [CrossRef]

156. Singh, M.; Kumar, P.; Kar, I. A Multi Charging Station for Electric Vehicles and Its Utilization for Load Management and the Grid Support. IEEE Trans. Smart Grid 2013, 4, 1026-1037. [CrossRef]

157. Lin, C.-C.; Peng, H.; Grizzle, J.; Kang, J.-M. Power management strategy for a parallel hybrid electric truck. IEEE Trans. Control. Syst. Technol. 2003, 11, 839-849. [CrossRef]

158. Zhang, T.-P.; Feng, C.-B. Decentralized adaptive fuzzy control for large-scale nonlinear systems. Fuzzy Sets Syst. 1997, 92, 61-70. [CrossRef]

159. Chen, Y.-M.; Huang, A.Q.; Yu, X. A High Step-Up Three-Port DC-DC Converter for Stand-Alone PV/Battery Power Systems. IEEE Trans. Power Electron. 2013, 28, 5049-5062. [CrossRef]

160. Moradisizkoohi, H.; Elsayad, N.; Mohammed, O.A. A Family of Three-Port Three-Level Converter Based on Asymmetrical Bidirectional Half-Bridge Topology for Fuel Cell Electric Vehicle Applications. IEEE Trans. Power Electron. 2019, 34, 11706-11724. [CrossRef]

161. Chandrasekar, B.; Nallaperumal, C.; Dash, S.S. A Nonisolated Three-Port DC-DC Converter with Continuous Input and Output Currents Based on Cuk Topology for PV/Fuel Cell Applications. Electronics 2019, 8, 214. [CrossRef]

162. Savio, A.D.; Juliet, A.V.; Bharatiraja, C.; Pongiannan, R.K.; Tariq, M.; Azeem, A. Development of Charging System for Multiple Electric Vehicle Using Bidirectional DC-DC Buck-Boost Converter. In Lecture Notes in Electrical Engineering; Springer: Berlin/Heidelberg, Germany, 2019; pp. 413-423.

163. Bishop, J.D.; Axon, C.J.; Bonilla, D.; Tran, M.; Banister, D.; McCulloch, M.D. Evaluating the impact of V2G services on the degradation of batteries in PHEV and EV. Appl. Energy 2013, 111, 206-218. [CrossRef]

164. Brooker, R.P.; Qin, N. Identification of potential locations of electric vehicle supply equipment. J. Power Sources 2015, 299 , 76-84. [CrossRef]

165. Tesfaye, M.; Castello, C.C. Minimization of impact from electric vehicle supply equipment to the electric grid using a dynamically controlled battery bank for peak load shaving. In Proceedings of the 2013 IEEE PES Innovative Smart Grid Technologies Conference (ISGT); IEEE: Piscataway, NJ, USA, 2013; pp. 1-6.

166. Zhang, Z.; Wang, J.; Wang, X. An improved charging/discharging strategy of lithium batteries considering depreciation cost in day-ahead microgrid scheduling. Energy Convers. Manag. 2015, 105, 675-684. [CrossRef]

167. Hu, X.; Hu, H.; Li, C.; Li, T.; Lou, X.; Chen, Q.; Hu, B. Cobalt-based metal organic framework with superior lithium anodic performance. J. Solid State Chem. 2016, 242, 71-76. [CrossRef]

168. Savio, A.D.; Juliet, V.A. Development of multiple plug-in electric vehicle mobile charging station using bidirectional converter. Int. J. Power Electron. Drive Syst. 2020, 11, 785-791. [CrossRef]

169. Ashtari, A.; Bibeau, E.; Shahidinejad, S.; Molinski, T. PEV Charging Profile Prediction and Analysis Based on Vehicle Usage Data. IEEE Trans. Smart Grid 2012, 3, 341-350. [CrossRef]

170. Li, Q.; Xiao, Y.; Zhao, S.; Zhu, X.; Wang, Z.; Liu, Z.; Wang, L.; Yan, X.; Wang, Y. Performance Status Evaluation of an Electric Vehicle Charging Infrastructure Based on the Fuzzy Comprehensive Evaluation Method. World Electr. Veh. J. 2019, 10, 35 . [CrossRef]

171. Nguyen, D.-D.; Nguyen, D.-H.; Funabashi, T.; Fujita, G. Sensorless Control of Dual-Active-Bridge Converter with Reduced-Order Proportional-Integral Observer. Energies 2018, 11, 931. [CrossRef]

172. Gabbar, H.; Othman, A.; Abdussami, M. Review of Battery Management Systems (BMS) Development and Industrial Standards. Technologies 2021, 9, 28. [CrossRef]

173. Aiello, O. Electromagnetic Susceptibility of Battery Management Systems' ICs for Electric Vehicles: Experimental Study. Electronics 2020, 9, 510. [CrossRef] 